Universidad de Lima

Escuela de Posgrado

Maestría en Dirección Estratégica de Contenidos

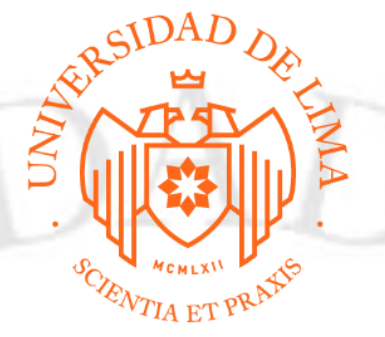

\title{
PROYECTO DE LARGOMETRAJE “EL CHALÁN" PRODUCIDO POR NOSTRADAMUS PRODUCCIONES
}

Trabajo de investigación para optar el Grado Académico de Maestro en Dirección Estratégica de Contenidos

César Ricardo Arana Díaz Alberto Matsuura Sonoda

Asesora

Natalia Ames Ramello

Lima - Perú 


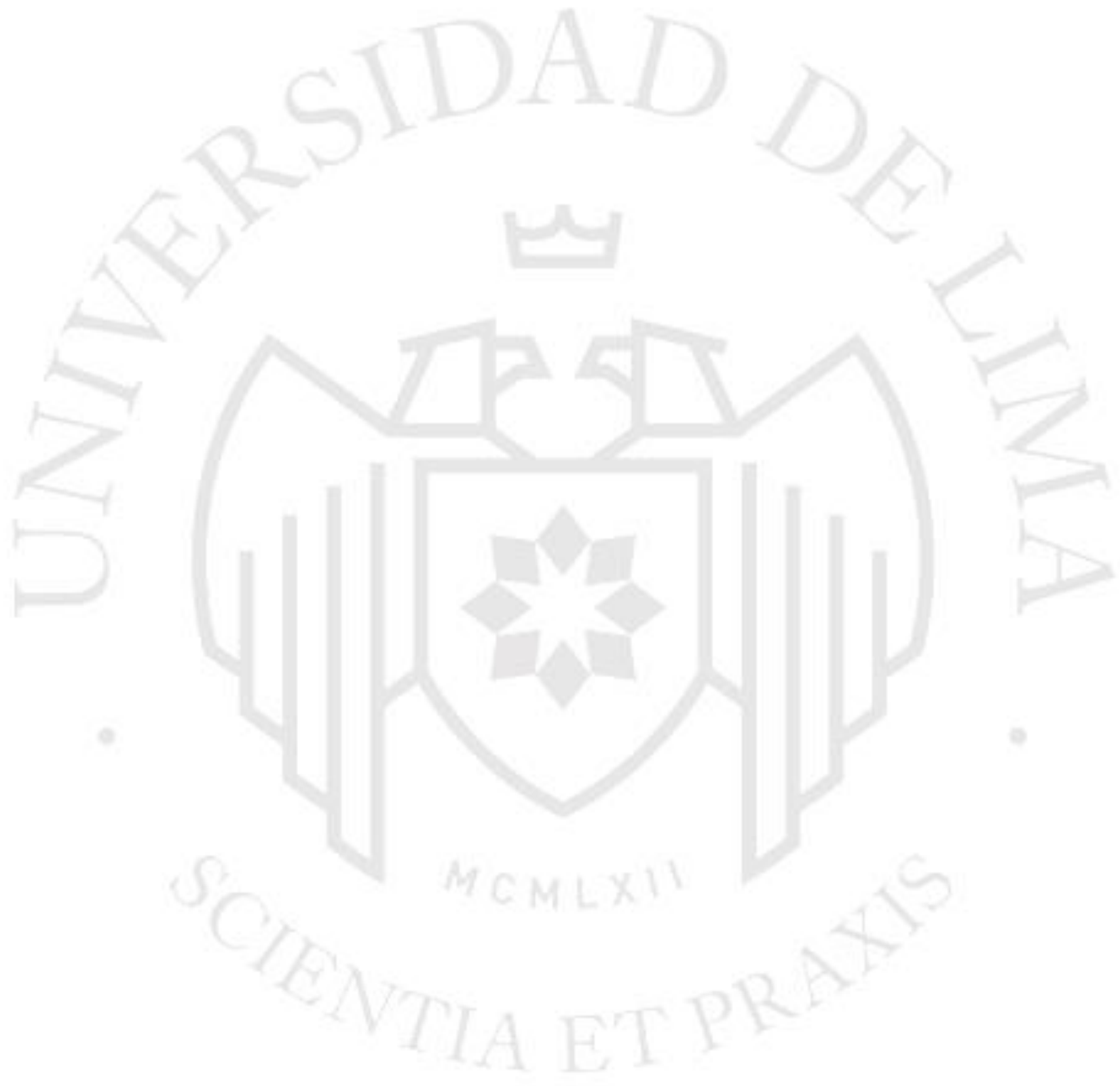




\section{PROYECTO DE LARGOMETRAJE " $E L$ CHALÁN" PRODUCIDO POR NOSTRADAMUS PRODUCCIONES}




\section{ÍNDICE}

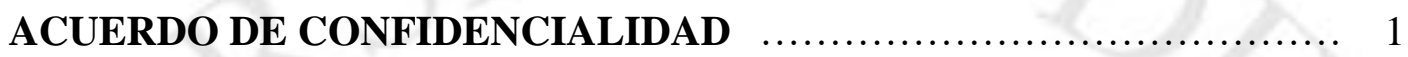

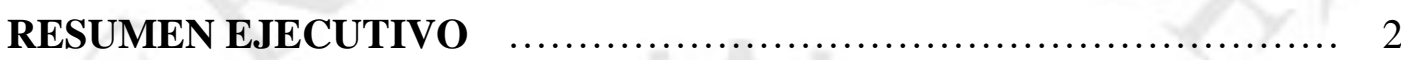

CAPÍTULO I: PRODUCTO AUDIOVISUAL ........................ 4

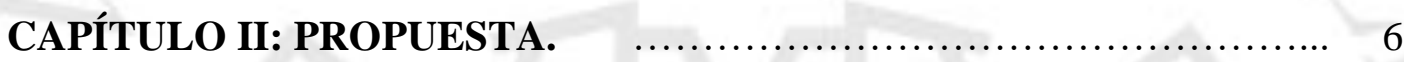

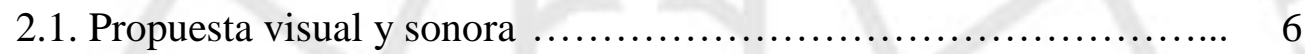

2.2. Justificación $\quad$............................................. 10

CAPÍTULO III: ANÁLISIS DE MERCADO .......................... 11

3.1.Mercado general (........................................ 11

3.2.Cambios en el mercado $\quad$..................................... 12

3.3.Segmentos de mercado $\quad$.................................... 14

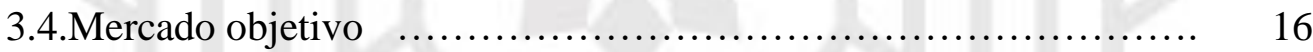

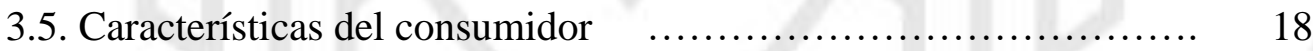

CAPÍTULO IV: ANÁLISIS DE LA COMPETENCIA ..................... 24

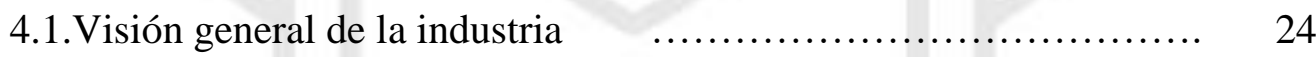

4.2. Número y tamaño de la declaración de los competidores ........... 25

4.3. Naturaleza de la competencia $\quad$............................. 26

4.4. Declaración de calidad $\quad$...................................... 27

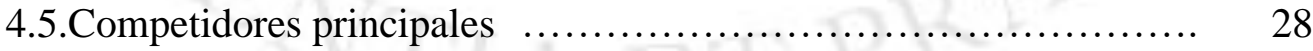

4.6.Oportunidades $\quad$........................................... 29

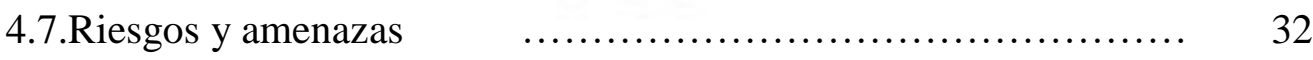

CAPÍTULO V: MARKETING .................................. 34

5.1.Posicionamiento ......................................... 34

5.2.Estrategia de promoción $\quad \ldots . \ldots \ldots \ldots \ldots \ldots \ldots \ldots \ldots \ldots \ldots \ldots \ldots . \ldots \ldots$

5.3. Plan de ventas $\quad$............................................. 41 
5.3.1 Festivales ................................................ 41

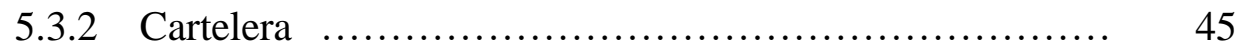

5.3.3 Plataformas ........................................ 47

CAPÍTULO VI: OPERACIONES ….................................... 50

6.1. Personal (directores, guionistas y compositores) ................. 50

6.2. Personal (técnico y artístico) ..................................... 55

CAPÍTULO VII: FINANZAS $\quad$...................................... 61

7.1.Presupuesto (según modelo DAFO) _ _........................ 61

7.2. Fuentes de financiamiento .......................................... 73

7.3. Fuentes de financiamiento alterno.................................... 73

CAPÍTULO VIII: CRONOGRAMA …....................................

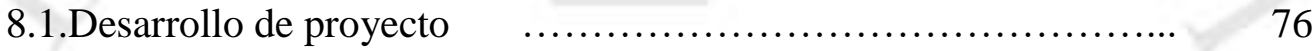

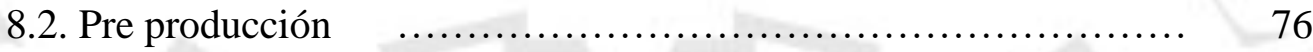

8.3. Realización $\quad$ ….............................................. 76

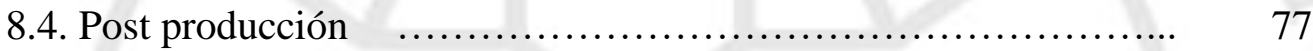

8.5. Distribución y Promoción ................................................. 77

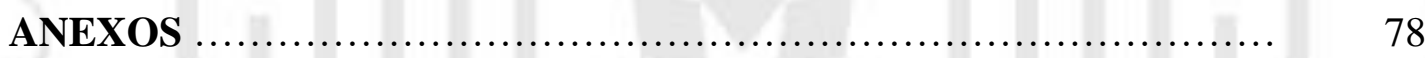

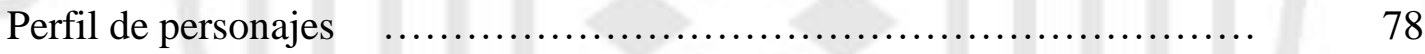

Contexto y Tratamiento $\quad$ ….......................................... 80

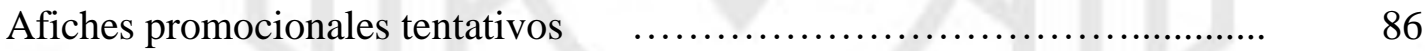

Entrevista a Beyker Bances, productor de película Pueblo Viejo ............ $\quad 89$

REFERENCIAS BIBLIOGRÁFICAS................................... 


\section{ACUERDO DE CONFIDENCIALIDAD}

Me gustaría recibir una copia del plan de emprendimiento audiovisual de la película El Chalán, producida por Nostradamus Producciones con el único fin de invertir posiblemente en este proyecto.

Reconozco que este plan contiene información confidencial y es de propiedad exclusiva, cuya divulgación puede causar daño financiero a sus propietarios. Acepto no hacer copias de ninguna porción de él, no divulgar el plan o cualquier parte de su contenido a terceros, y no hacer ningún uso del mismo que no sea para considerar la posibilidad de invertir en la película El Chalán, producida por Nostradamus Producciones.

Acepto devolver el plan y cualquier documento de acompañamiento a los propietarios del mismo, puntualmente, cuando haya completado mi revisión, cuando ya no tenga interés en considerar la posibilidad de invertir en él, cuando sea solicitado por sus propietarios, o lo que ocurra primero.

Nombre:

Firma:

Fecha: 


\title{
RESUMEN EJECUTIVO
}

\author{
PROYECTO DE PELÍCULA “EL CHALÁN”, PRODUCIDA POR \\ NOSTRADAMUS PRODUCCIONES
}

\section{Concepto de proyecto}

Somos parte de la industria del entretenimiento en la categoría audiovisual. Nuestro mercado objetivo es, principalmente, jóvenes adultos peruanos. Nuestra línea de producto principal es una película, la misma que busca dar origen a contenidos para otras plataformas como, por ejemplo, una serie. Y se diferencia de los competidores por el género que maneja (western - acción), los personajes carismáticos, la calidad artística y el tratamiento audiovisual.

\section{Situación actual}

El antecedente del proyecto es el cortometraje El Chalán, dirigido por Alberto Matsuura. (link para ver el corto).

La idea del proyecto es adaptar los personajes y la historia a un largometraje con el objetivo de ganar prestigio y posicionar a los realizadores y a Nostradamus Producciones en el mercado audiovisual. Más adelante, se buscará seguir las aventuras del personaje protagónico y extender el universo creado en una serie para plataformas de streaming. 
El Chalán es un western peruano que utiliza elementos propios del género western (personajes heroicos, códigos de honor, duelos, etc.) combinados con elementos peruanos (El Chalán, caballos de paso, paisajes etc.).

Actualmente se encuentra en la etapa de desarrollo. No hay un guion terminado, por lo que uno de sus mayores retos será obtener un incentivo financiero que permita darle forma definitiva al proyecto. Su mayor oportunidad es contar con el cortometraje, ya que este es la versión tangible de las ideas planteadas. Además, es un producto que ha sido validado por el público y la crítica al recibir diversos premios en festivales: el premio del público en el festival FENACO de Cusco; el mejor corto peruano en el festival La Noche de los Cortos; mejor música en el festival de Texas (EE.UU.); mejor producción y música en el concurso de CONACINE y selección oficial en muchos más.

\section{$\underline{\text { Factores clave }}$}

Los factores clave de éxito del proyecto son:

1. Un universo narrativo basado en figuras tan icónicas y reconocibles para los peruanos como el caballo de paso y el chalán presentadas de manera diferente con la mezcla de los códigos del género western.

2. Una propuesta audiovisual cuidada y de calidad.

3. Una combinación de actores de larga trayectoria (José Luis Ruiz, Reynaldo Arenas, María Angélica Vega) con actores jóvenes (Mayra Goñi, Gustavo Borjas) para asegurar la experiencia y la llegada a diferentes audiencias.

4. Una propuesta de acciones de marketing apelando a la viralidad. 


\section{CAPÍTULO I: PRODUCTO AUDIOVISUAL}

Título de obra: El Chalán

\section{Storyline:}

La película es un western peruano y la historia gira en torno al personaje llamado El Chalán quien en busca de justicia tendrá que enfrentarse al Cuto para superar sus fantasmas del pasado ayudando a Claudia y a su hija La Peque.

Géneros: Western - Acción

\section{Motivaciones del director $y$ el productor:}

Son varias las motivaciones para hacer esta película:

- A nivel creativo, hay una necesidad de plasmar el concepto de la mezcla del género western con elementos peruanos y crear un personaje icónico con una mitología rica que pueda enganchar al público. Además, cultivar el orgullo por una película peruana sin lenguaje grosero ni desnudos.

- A nivel cinematográfico, muchas de las películas peruanas actuales son prácticamente "telefilms" (es decir, productos que tienen un manejo de lenguaje audiovisual muy básico: planos generales, plano contra plano, iluminación en clave alta y plana, sin mayor complejidad, simplemente buscan cubrir la escena) por lo que hay una necesidad de plantear un trabajo mucho más desarrollado del lenguaje cinematográfico. 
Si bien las cualidades artísticas de todo proyecto cinematográfico o audiovisual pasan por cierto matiz de carácter subjetivo, la afirmación que hacemos (de carácter personal) se refiere básicamente al hecho que la mayoría de películas peruanas actuales apuestan por replicar fórmulas y convenciones fácilmente reconocibles e identificables para las audiencias al interior de su propuesta audiovisual; incluso, muchas de ellas recurren a rostros y personajes mediáticos cercanos al público espectador. A esto, hay que sumarle que el discurso, la narrativa y el lenguaje sobre los cuales se trabaja (en algunos casos, no en todos) nos acercan más a convenciones y códigos propios de los telefilmes que de los contenidos cinematográficos propiamente dichos.

- A nivel de mercado, se busca posicionar al personaje protagonista y su universo ficcional y, a partir de esto, generar productos, así como contenidos derivados que pueden ser distribuidos en diferentes plataformas.

- A nivel emotivo, El Chalán es un homenaje al género Western y al Perú. 


\section{CAPÍTULO II: PROPUESTA}

\subsection{Propuesta visual y sonora}

La propuesta visual está directamente influenciada por el spaghetti western, subgénero del western que fue delineado por el director italiano Sergio Leone. Este es uno de los aspectos más destacados del proyecto y que, además, se puede apreciar en el cortometraje El Chalán. Las características visuales son las siguientes:

Se trabajará con un formato de pantalla 2.35:1 para aprovechar los espacios abiertos y la belleza de los paisajes peruanos.

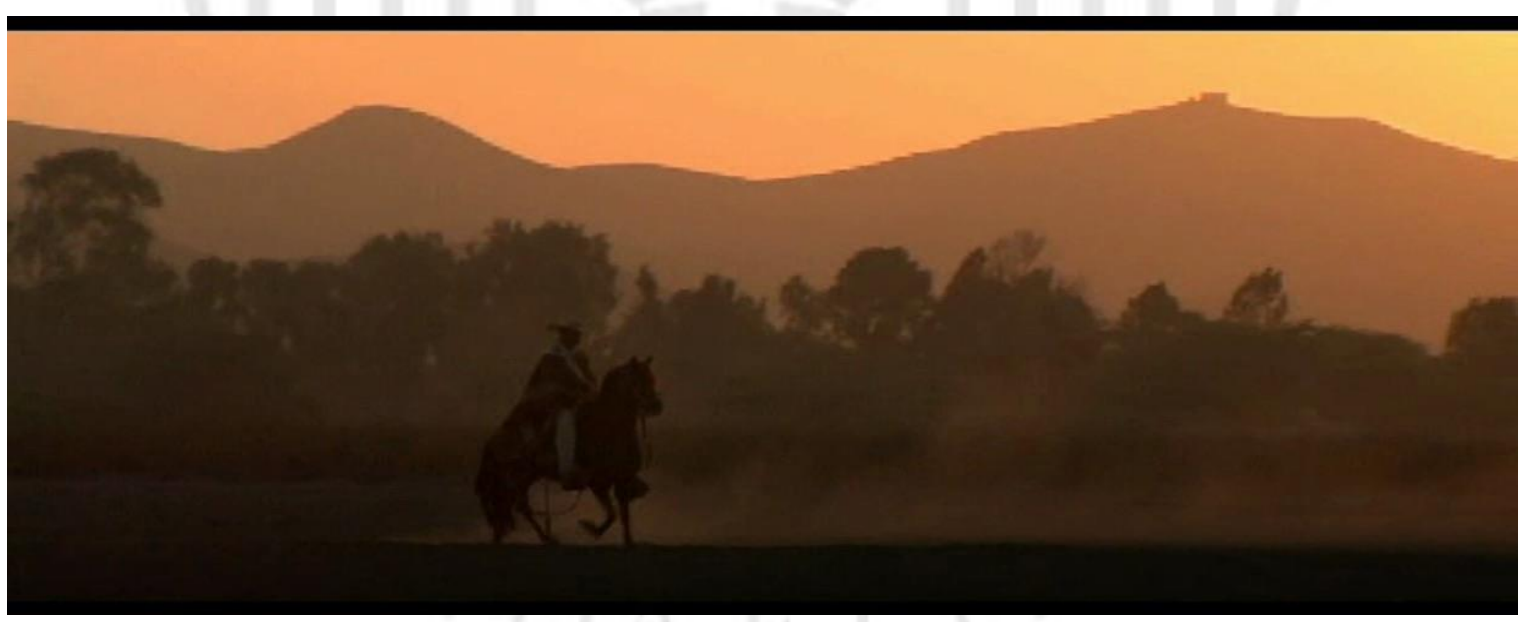

Al tener este formato, la composición del encuadre será clave. Se utilizará una composición en varios términos. 


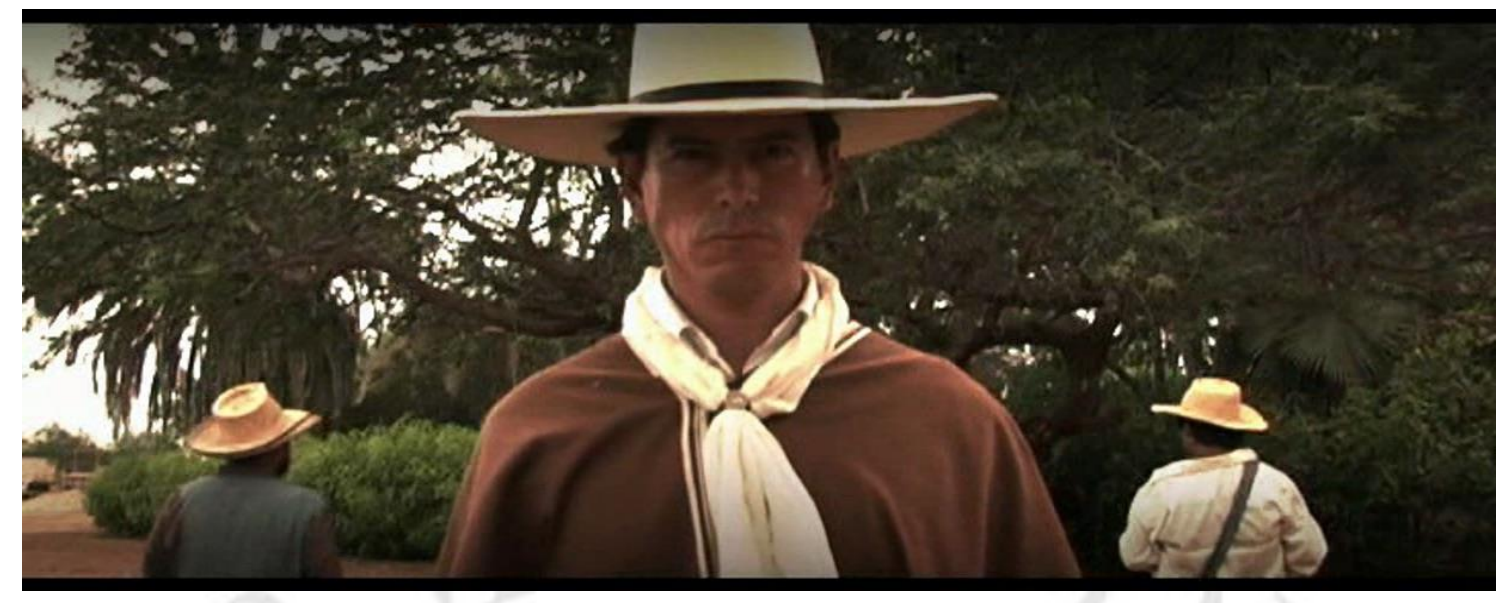

La profundidad de campo irá variando según las necesidades narrativas y visuales: gran profundidad de campo cuando se tenga diversos personajes en el encuadre o cuando tengamos grandes planos generales, pero la profundidad de campo será menor cuando tengamos primerísimos primeros planos.
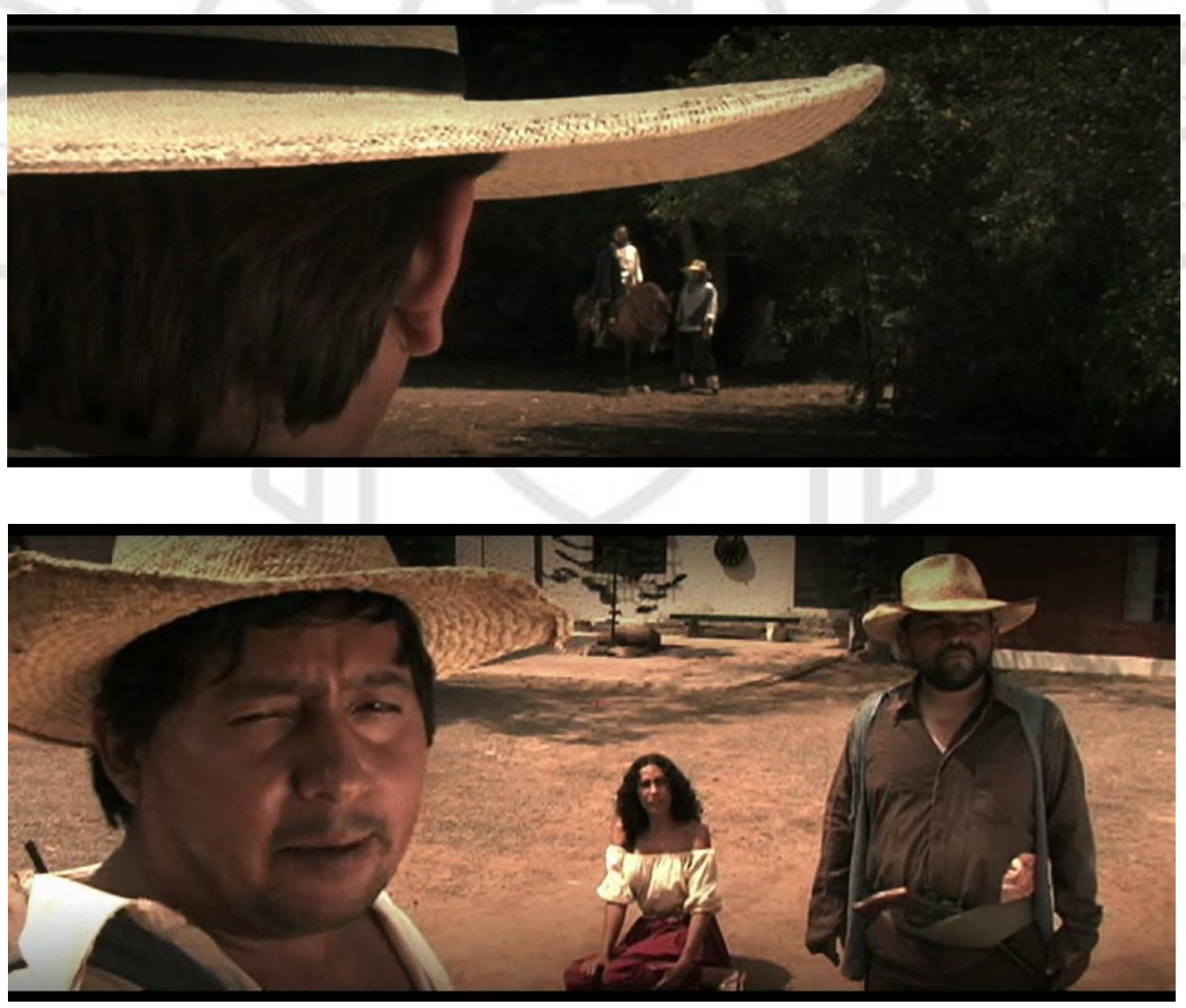


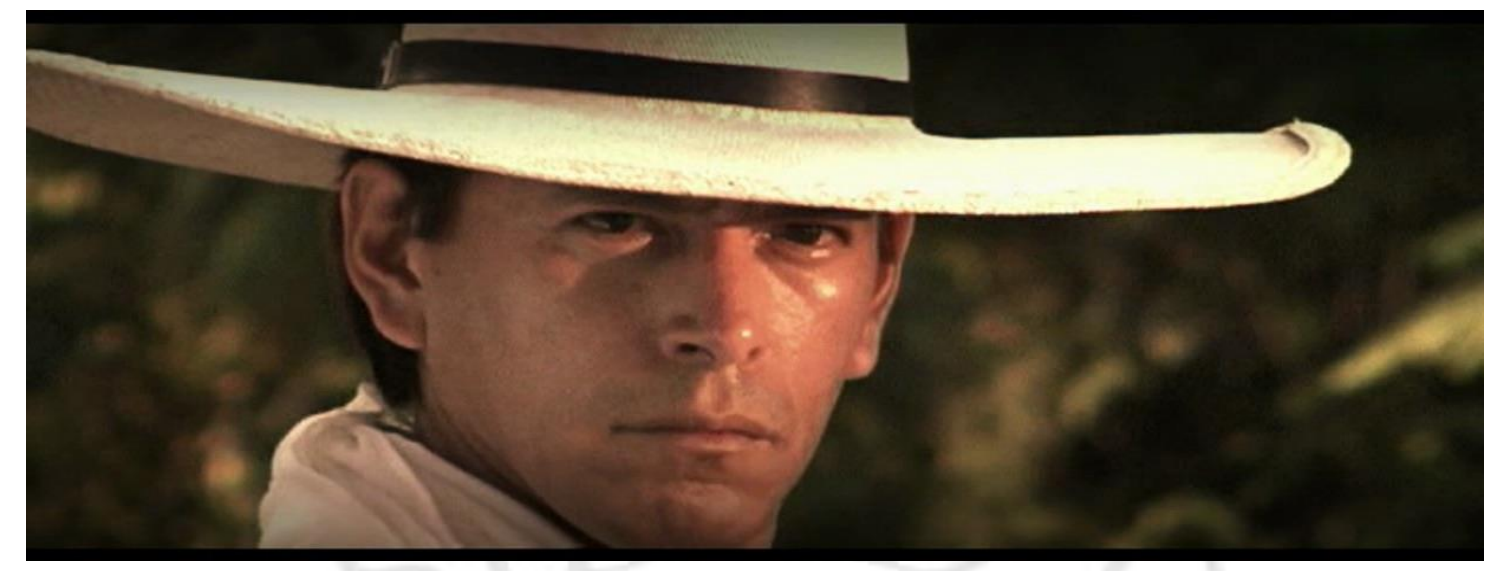

El color estará, ligeramente, decolorado y virado al sepia para darle ese toque antiguo y clásico.

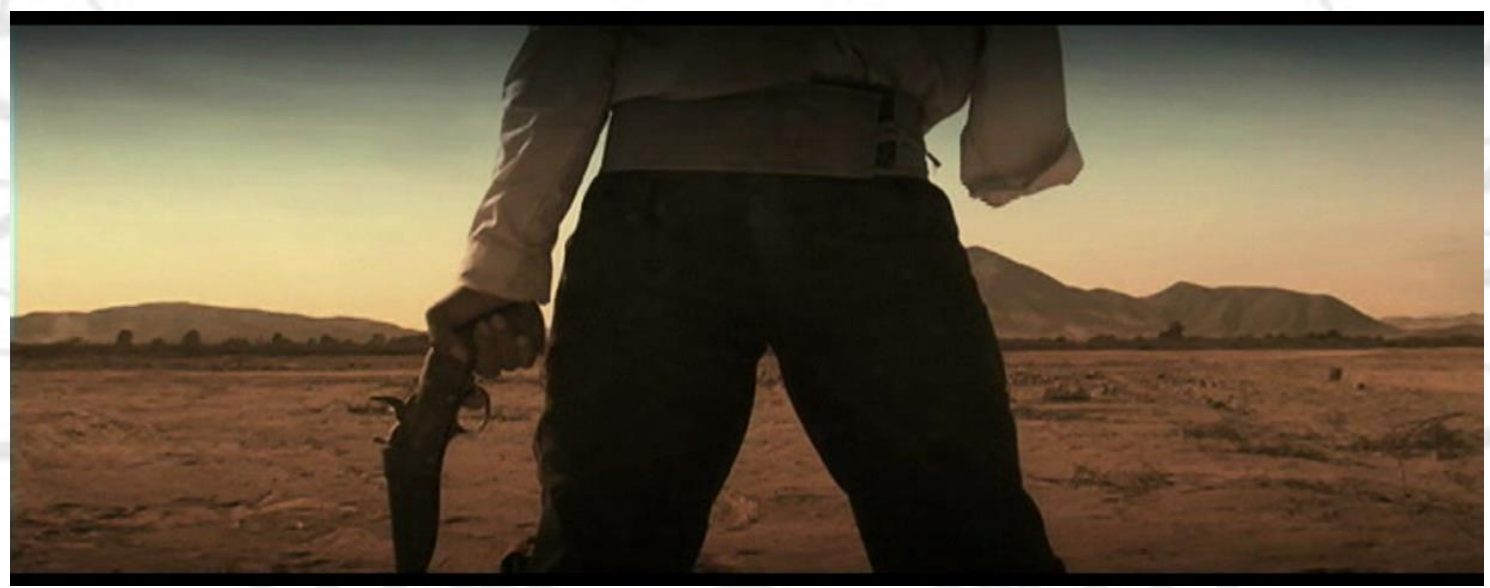

La paleta de color estará compuesta por colores tierra: entre marrón, crema y granate, contrastados con colores como el azul oscuro y el verde.

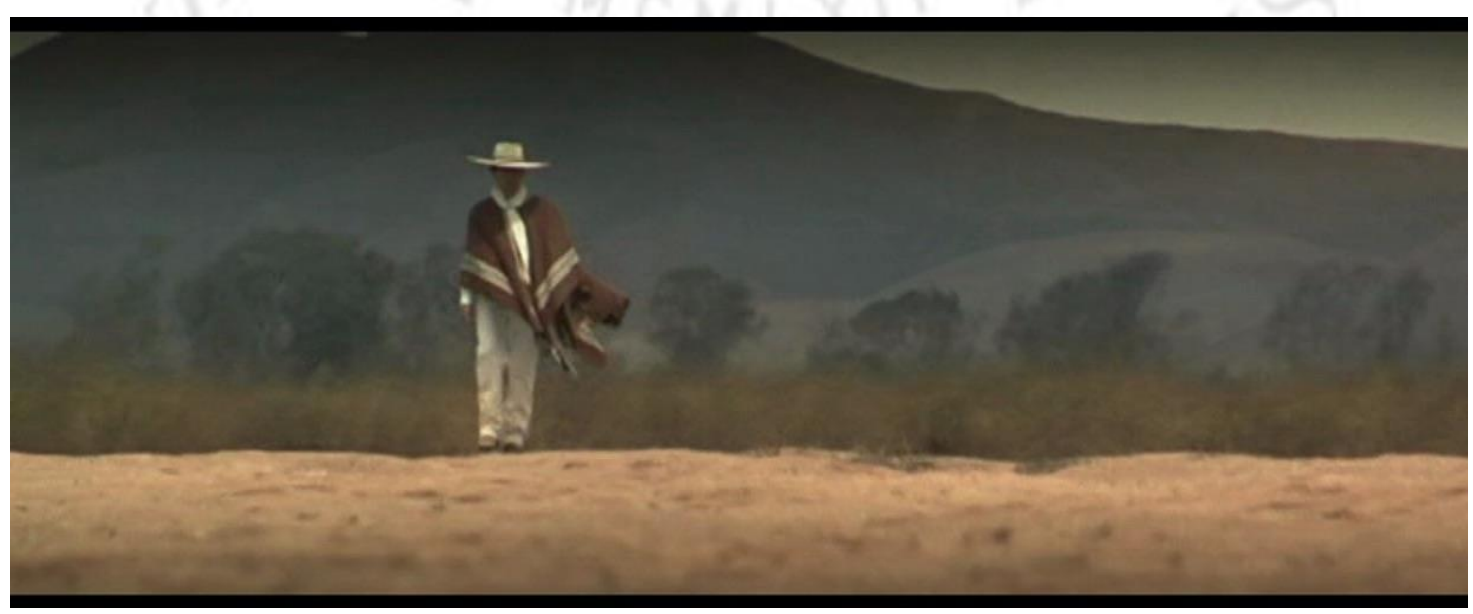



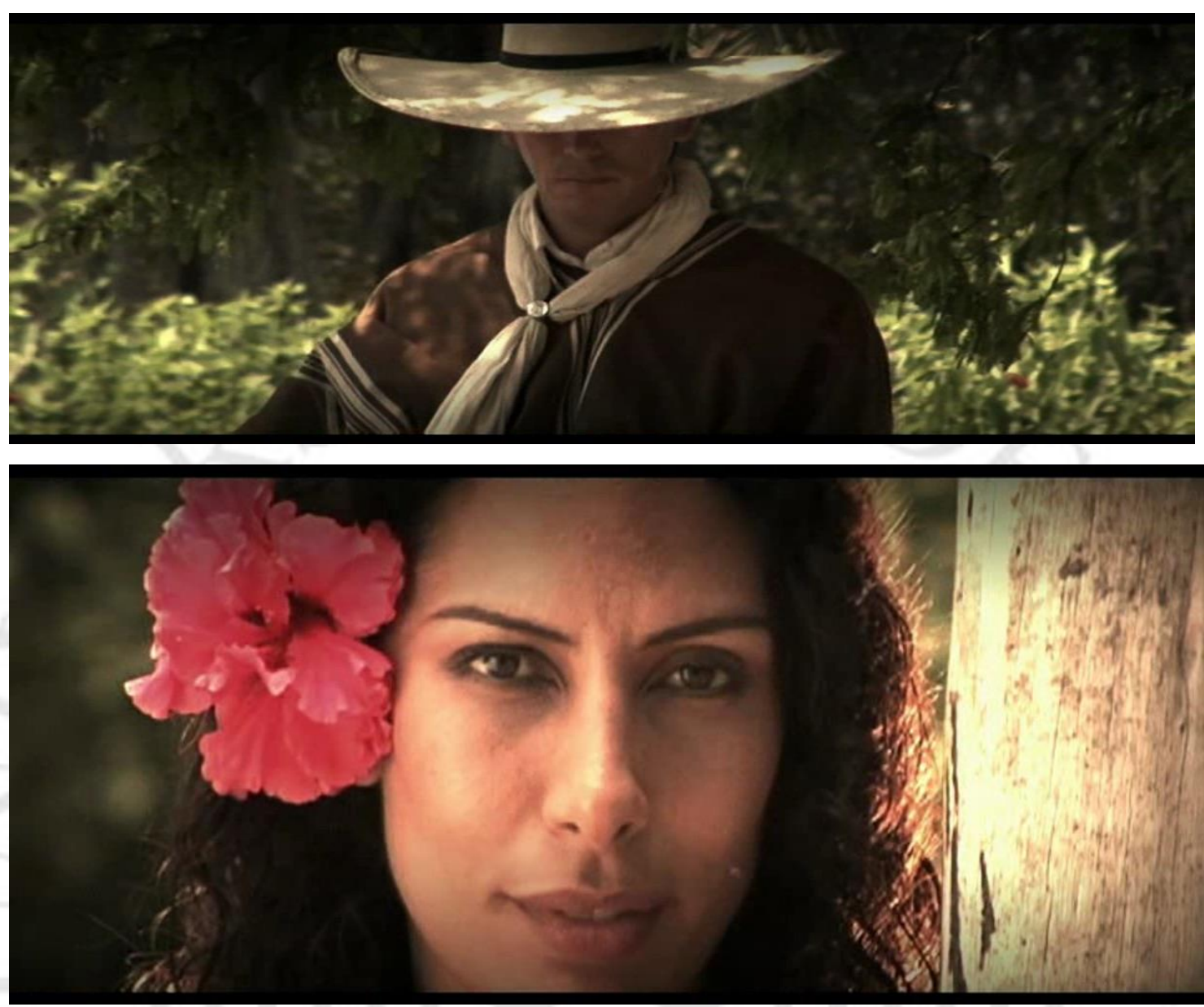

En cuanto a la propuesta sonora se mantiene el concepto de mezclar el western con lo peruano como, por ejemplo, el uso de la música criolla al inicio del video "El chalán: Un western peruano". ${ }^{1}$

Además del uso de instrumentos peruanos no como una composición musical, sino para generar atmósfera, como en la escena del minuto 8:25. ${ }^{2}$

En varios momentos, el protagonismo lo tendrán los sonidos en primer término para generar tensión en la narración, como en la escena del minuto 11:49. ${ }^{3}$

Cabe destacar que otro de los elementos celebrados del cortometraje fue su música al ganar el premio de mejor música en el festival de Texas (EE.UU.) y el concurso de cortos nacionales CONACINE.

\footnotetext{
${ }^{1}$ Matsuura, A. (19 de mayo de 2014). Youtube. Obtenido de Youtube: https://www.youtube.com/watch? $\mathrm{v}=\mathrm{ss} 1 \mathrm{~W} 8 \mathrm{vIKH} 9 \mathrm{w} \&$ feature $=$ youtu.be $\& \mathrm{t}=5$ ${ }^{2}$ Video "El chalán: Min 8:25"

3 Video "El chalán: Min 11:49"
} 
En cuanto a la edición, a diferencia del cortometraje, se busca un ritmo mucho más dinámico y no tan pausado. En ese aspecto, la referencia directa sería la película coreana "El bueno, el malo y el raro". 4 (Kim, 2008)

\subsection{Justificación}

Todo nace del concepto de mezclar el western con lo peruano y de las referencias cinematográficas.

A nivel de historia y estructura, el proyecto es clásico y directo. Se toma de referencia al western americano clásico y a la película Star Wars (1977). El proyecto también se plantea con una narración episódica, donde el personaje principal, El Chalán, puede pasar de una aventura a otra de película en película como el personaje de Indiana Jones.

A nivel de personajes se desarrollará un conflicto interno del protagonista relacionado a su pasado con el antagonista, esto podría aportar a pensar en la posibilidad de desarrollar en mayor medida el arco de transformación del mismo.

A nivel visual, se toma las referencias del Spaghetti Western, principalmente la obra maestra Érase una vez en el oeste (1968) del director italiano Sergio Leone, entre otras. Todo mezclado con personajes como El Chalán, el caballo de paso, el pisco y paisajes que parecen del norte peruano como Piura.

A nivel sonoro, la gran influencia es el trabajo del legendario músico Ennio Morricone y su propuesta casi experimental de la música y los sonidos que realizó para las películas del Spaghetti Western.

\footnotetext{
${ }^{4}$ Se puede ver en EL BUENO, EL MALO Y EL RARO de Kim Jee-Woon (Trailer español) en Youtube: https://www.youtube.com/watch?v=f9LAzMeSU8g
} 


\section{CAPÍTULO III: ANÁLISIS DE MERCADO}

\subsection{Mercado general}

Hablar, hasta hace unos años, de producción cinematográfica en la región y, sobre todo, en el caso de un país como el Perú, nos enfrentaba a un panorama bastante desolador.

Sin embargo, en los últimos años, este panorama ha ido cambiando y, si bien aún no podemos hablar de una industria cinematográfica propiamente dicha, algunas cifras son bastante alentadoras y nos hacen ver con optimismo el futuro del sector a nivel local y regional.

Según el estudio Global Entertainment \& Media Outlook (2018-2022), elaborado por la firma de servicios profesionales $\mathrm{PwC}$, la industria cinematográfica en el Perú pasaría de generar ingresos por US\$ 184 millones en el 2017 a US\$ 244 millones en 2022, lo que logró un crecimiento de 32,6\%. De esta manera, se prevé en promedio una tasa de crecimiento anual compuesta (TCAC) de 5,8\% para el 2022.

La afluencia de público a las salas de cine creció en 20 millones durante el periodo 20132017, hasta alcanzar un estimado de 54 millones de personas. El estudio proyecta que la tendencia se mantendría y se espera alcanzar los 68.5 millones de asistentes al cine para el 2022. (Gestión Empresas, 2019)

En líneas generales, la actividad cinematográfica se ha visto fortalecida en la región; sin embargo, la brecha existente entre un mercado como el peruano y el resto de los países de esta parte del continente continúa siendo bastante grande. A nivel de Latinoamérica, es importante destacar que, según los indicadores de este mismo informe: 
El Perú figura cuarto en el movimiento de la taquilla en América Latina para el 2022 (US\$ 230 millones), solo superando a Argentina (US\$ 176 millones) y Chile (US\$ 169 millones) ....Sin embargo, tiene un gran margen en comparación a Brasil (US\$ 1.150 millones), México (US\$ 981 millones) y Colombia (US\$ 268 millones). (Gestión Empresas, 2019).

Con respecto al número de salas de cine en 2018, el número a nivel nacional era de 661 y llegaría a sumar 789 para 2023. Es decir, cada año el número de salas de cine en el país crecería 3.6\% durante el próximo lustro. En total, se registraría un aumento de 19.3\% comparado a la cifra de 2018. (Perú 21, 2019)

Por otro lado, los niveles de producción están aumentando en América Latina y apuntan a un fortalecimiento del apoyo gubernamental a las industrias locales, factor que podría impulsar el crecimiento de la industria en la región. En el Perú, se ha atravesado por un largo y complejo proceso para llegar a la nueva ley de cine. El Congreso de la República aprobó el 8 de mayo del 2019 la Ley de Promoción de la Actividad Cinematográfica, con esta ley se espera dinamizar la producción y la formación audiovisual, la implementación de salas de exhibición, festivales, la producción de documentales, ficciones, series, entre otros.

Se detallará el impacto de la nueva ley de cine en el apartado de oportunidades.

El caso peruano no deja de ser un caso sui generis: variables como la coyuntura política, coyuntura social, situación económica, variables de moda, incursión de personajes mediáticos, reconstrucción de eventos relevantes del acontecer local han impactado en muchas ocasiones en las propuestas cinematográficas locales.

\subsection{Cambios en el mercado}

Acostumbrados durante décadas a un panorama bastante sombrío, que quizás atravesó su momento más crítico hacia los años ochenta como resultado de la crisis económica y la lucha subversiva, la cinematografía local comienza a experimentar una serie de cambios y transformaciones que marcan un nuevo camino para su desarrollo. 
Sería demasiado pretencioso hablar de la consolidación de una industria cinematográfica propia, pero el panorama en términos generales fue tornándose mucho más optimista. Nathalie Hendrickx y Augusto Tamayo mencionan dos años claves en su libro Financiamiento, distribución y marketing del cine peruano: “el 2006 por la cantidad de películas estrenadas y por el impacto que estas tuvieron en el negocio; y el 2015 por la consolidación de la producción, ya que se llegó a tener hasta 3 películas peruanas en cartelera al mismo tiempo”. (Tamayo \& Hendrickx, 2018, pág. 169)

Pero ¿Dónde podríamos ubicar el hito que de alguna manera marca un giro de tuerca para la producción cinematográfica local?

A nivel de mercado, el 2013 marcó un antes y un después: la película Asu mare producida por Miguel Valladares llevó a más de 3 millones de espectadores a las salas cinematográficas locales, lo que triplicó la cifra de la película más exitosa hasta ese momento; La fuga del Chacal de Augusto Tamayo en 1987, que llegó a los 980 mil espectadores ¿Qué ocurrió después? Otro éxito, hasta cierto punto inesperado, continuó dando señales que algo estaba ocurriendo; en el 2013, la película Cementerio general de Dorian Fernández logró llevar cerca de 800 mil espectadores.

¿En qué aspectos reside la relevancia de estos dos proyectos? Básicamente, en dos razones esenciales: en primer lugar, comienza a definirse muy claramente un modelo de producción cinematográfica poco probable hasta esta época; los inversionistas locales y el capital privado comienzan a percibir a la producción cinematográfica como un modelo de producción rentable y capaz de generar importantes márgenes de ganancia; el cine comienza a ser visto como un negocio rentable. En segundo lugar, esto posibilita que la dinámica de negocio propio del sector se impregne de un nuevo aire y tome un gran impulso.

En cuanto a la recaudación a nivel de taquilla, tanto en el caso de Asu Mare como en el de Cementerio General, se evidencia un salto cuantitativo realmente importante en el cine peruano para este momento. Ambos proyectos logran superar con creces a nivel de recaudación y recepción, las proyecciones establecidas por sus propios productores y realizadores. En el conversatorio ¡Asu mare! Explicaciones detrás del boom, organizado por el Instituto de Investigación Científica (IDIC) de la Universidad 
de Lima, Miguel Valladares, uno de los principales artífices de la propuesta, expresó lo siguiente: “...en las reuniones para convencer a las empresas a que auspiciaran el producto, el equipo estimaba que ¡Asumare! superaría la valla de los 500 mil espectadores, sin imaginar que la película sería vista finalmente por más de 2 millones de personas...”. (Instituto de Investigación Científica de la Universidad de Lima, 2013)

Ante esta respuesta, la empresa privada peruana comienza a percibir con menor grado de riesgo la posibilidad de invertir en proyectos cinematográficos locales; la estabilidad económica y política que se vive durante estos años, así como la sensación general de "un futuro mucho más optimista", contribuyen a percibir como una alternativa interesante de inversión y de negocio a la actividad cinematográfica.

En el mismo conversatorio Ricardo Maldonado, director de la película, menciona que:

...uno de los primeros pasos que dio el equipo de ¡Asu mare! fue solicitar un estudio de mercado que consistió en consultar al público sobre su opinión de una película protagonizada por Carlos Alcántara, cuyos resultados arrojaron que la idea del proyecto generaba una aceptación superior al 90\%”. (Instituto de Investigación Científica de la Universidad de Lima, 2013)

Además, está la opinión de Liuba Kogan, antropóloga, quien resaltó lo siguiente:

¡Asu mare! es un relato de éxito y superación personal que coincide con un contexto de crecimiento económico estable y único en la historia del país que ha renovado el orgullo por lo que se realiza en el Perú, y que el protagonista del filme, en lugar de insultar a los demás para hacer reír, se burla de sí mismo, lo que genera empatía. (Instituto de Investigación Científica de la Universidad de Lima, 2013)

\subsection{Segmentos del mercado}

El mercado cinematográfico local ha definido sus audiencias de la mano (y de manera muy directa) a partir de la presencia de géneros que han logrado establecer con 
absoluta claridad los gustos y preferencias del público. El género que ha logrado situarse y consolidarse como el favorito del público con respecto a las películas peruanas es sin duda alguna la comedia. Junto a ella, podemos encontrar presentes otros géneros que han contribuido a configurar los gustos de las audiencias locales como el drama, la acción, el musical, etc.

Figura 3.1

\section{Porcentaje de asistencia por género en 2018}

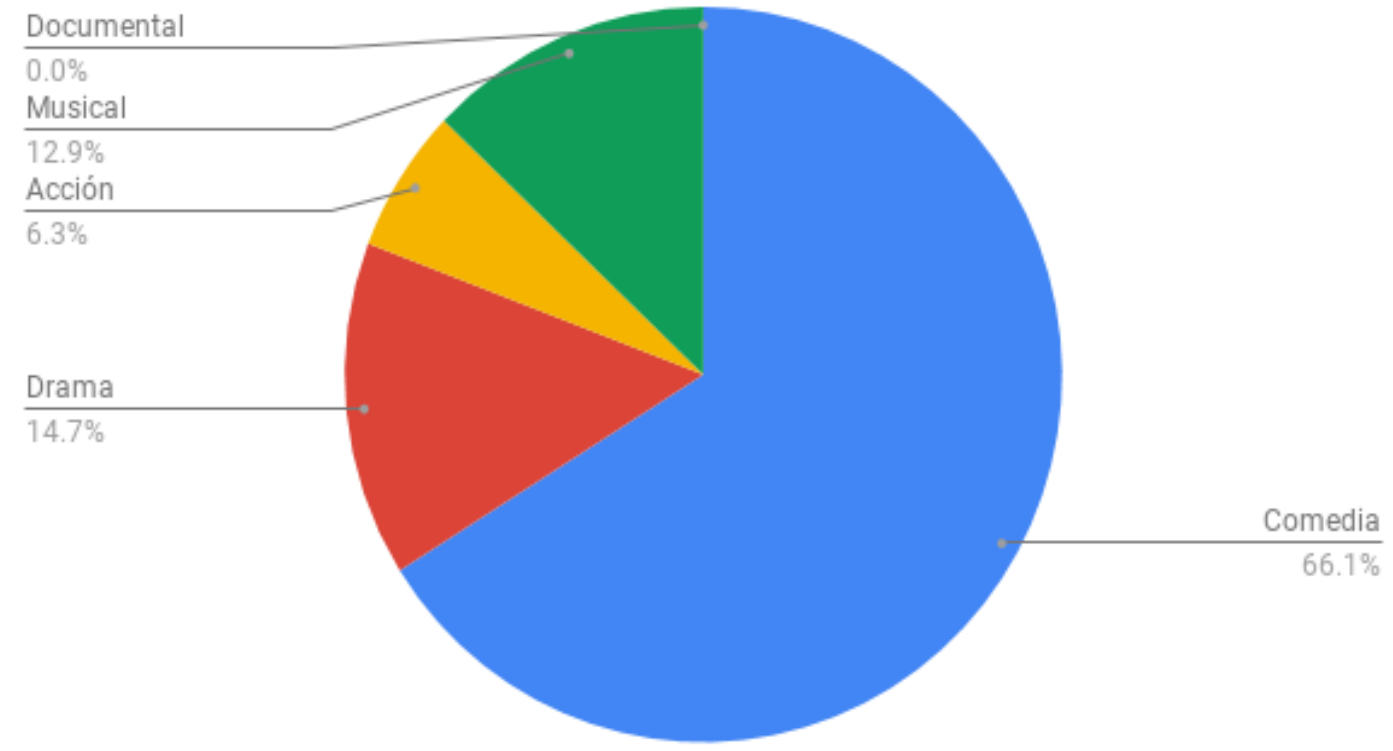

Fuente: Cinencuentro. (Chávez, Cineencuentro, 2019)

Pero a nivel general de la cartelera, al parecer, los peruanos prefieren el género de acción, así lo reveló una encuesta realizada por la empresa de Ecommerce Peixe Groupon a más de 2000 personas en agosto del 2019. 
Figura 3.2

\section{Géneros más buscados por peruanos}

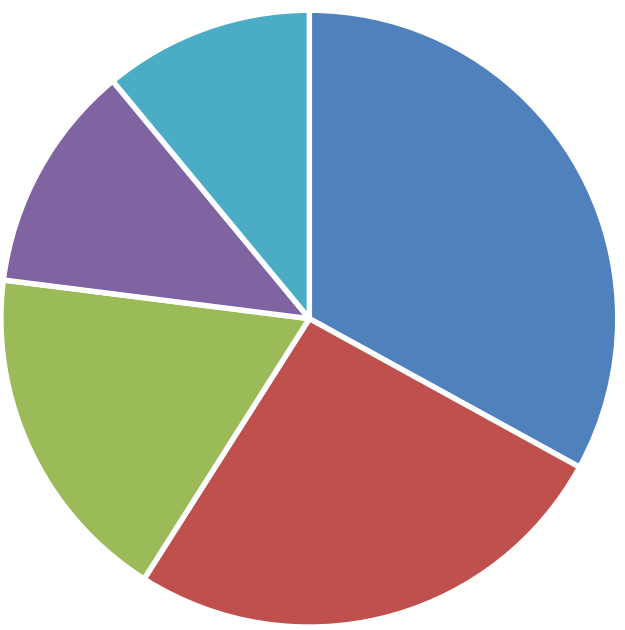

- Acción - Ciencia ficción - Comedias - Infantiles - Otros

Nota: "Los géneros más buscados por los peruanos son acción (33\%), ciencia ficción (26\%), comedias (18\%) e infantiles (12\%)". (Zegarra, 2019)

Fuente: ItUsers

Esta encuesta puede hacer referencia al actual boom en taquilla de las películas de superhéroes desarrolladas principalmente por Marvel Studios. Este es un fenómeno mundial que viene afectando directamente a la recaudación de taquilla en todo el mundo, definitivamente no se puede competir a nivel de marketing y de producción con estos blockbusters y este tipo de producciones, pero es interesante ver que el público peruano puede estar abierto a propuestas diferentes a la comedia , El Chalán pretende capitalizar esto a su favor aprovechando el posicionamiento heroico del personaje del chalán y el tratamiento de un género como la acción.

\subsection{Mercado objetivo: caso múltiples mercados objetivo}

Nuestro principal segmento de mercado objetivo será el mercado local; sin embargo, dentro de un contexto en el cual los patrones de consumo vienen presentando cambios importantes, se observa también que el rol de las audiencias adquiere una naturaleza mucho más participativa y autónoma: se vienen definiendo audiencias mucho 
más exigentes y segmentadas, a partir de las cuales se comienzan a prestar atención a nuevas opciones en cuanto a plataformas; las estrategias entonces deben apuntar a la captura de múltiples mercados.

Esta afirmación es el resultado de la observación de las tendencias de consumo actuales:

La televisión y el cine dejaron de acaparar la atención de las audiencias ávidas de entretenimiento cuando apareció YouTube, en 2005. Y a medida que surgían las plataformas de streaming, como Netflix, Amazon Prime y HBO Go, a las que se puede acceder desde dispositivos portátiles, la competencia se ha exacerbado. El televisor y su programación de señal abierta (e incluso la de señal por cable) empiezan a resultar accesorios en algunos hogares. Los hábitos de consumo se tornan cada vez más personalizados. Y salvo en el caso del fútbol, la idea de públicos masivos, pegados a la pantalla de un mismo canal, y a la misma hora, se vincula más al pasado que al presente. (Velásquez, s.f.)

La aparición de conceptos como "maratonear", "nesting”, "prosumidor" nos da una idea más clara de estos cambios en los hábitos de consumo, en donde prima una experiencia cada vez más solitaria y personalizada.

Un estudio del antropólogo canadiense Grant McCrackken sobre el consumo de Netflix identificó que los usuarios visualizan de forma continua, y por muchas horas, los capítulos de una misma serie: “... desarrolló el concepto de Nesting -anidar, en castellano... Este consiste en permanecer todo el fin de semana en casa sin ocuparse de alguna tarea en específico." (Velásquez, s.f.)

Los lineamientos de acción planteados y esbozados por las empresas líderes del mercado están apuntando a eso y van marcando de manera bastante clara el camino por seguir.

Tondero se ha posicionado como la productora líder a nivel local. A partir del éxito de Asu mare, logra brillar en el panorama local como la empresa productora de películas capaz de desarrollar un ritmo de producción continuo y parejo, que establece un 
modelo de negocio muy poco probable para una realidad como la peruana hasta hace algunos años. Su despegue como productora de películas propicia, incluso, que su principal y original segmento de negocio, la representación de artistas, quede relegado a un segundo plano. No obstante, algunos resultados obtenidos a partir de sus últimas producciones los han llevado a replantear modelos, fórmulas y estrategias.

La producción de series, la distribución de contenidos a nivel internacional y la comercialización de los mismos en diferentes plataformas se están convirtiendo en los caballos de batalla para hacer frente a los cambios que vienen presentando el mercado y las necesidades de un público cada vez más exigente y segmentado.

Nuestra propuesta apunta a este modelo de negocio, un modelo que no solo se concentre en las posibilidades que ofrezca el mercado local a nivel de taquilla, sino que apunte también a satisfacer las necesidades de mercados más allá del local y de plataformas más allá de las salas de cine.

\subsection{Características del consumidor}

En la encuesta realizada por la empresa de E-commerce Groupon - Peixe se especifica el siguiente comportamiento acerca de los hábitos cinematográficos de los peruanos: 


\section{FRECUENCIA:}

Figura 3.3

\section{FRECUENCIA DE IR AL CINE}

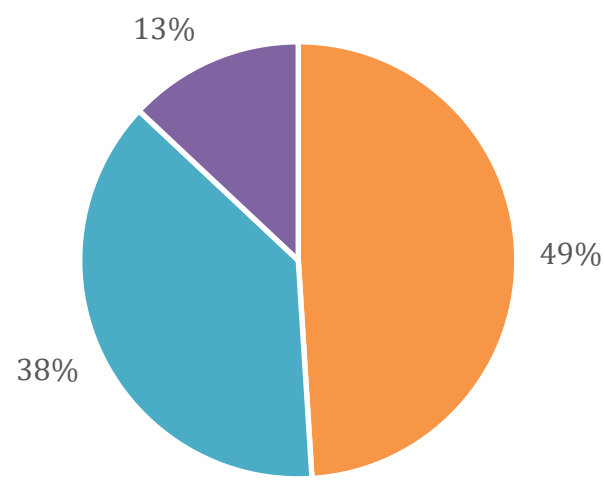

- 1 vez a la semana $\quad 1$ vez al mes $\quad$ otros

Nota: " $49 \%$ de los encuestados en Perú afirmó que va al cine al menos una vez a la semana, mientras el $38 \%$ va al menos una vez al mes. Esta cifra convierte a los peruanos en los más cinéfilos de Latinoamérica sobre países como Chile, Colombia, Argentina y México." (Zegarra, 2019) Fuente: It Users

Figura 3.4
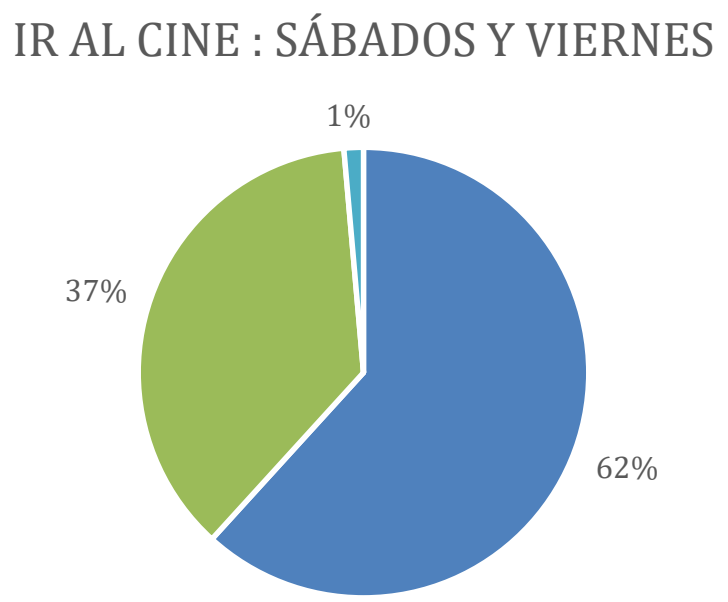

- Jornada noche $\quad$ - Jornada tarde $\quad$ - Otros

Nota: "Los días sábado (31\%) y viernes (26\%) son los preferidos en las jornadas de la noche (62\%) y tarde (37\%) para ir al cine”. (Zegarra, 2019) Fuente: It Users 


\section{ELECCIÓN:}

Figura 3.5

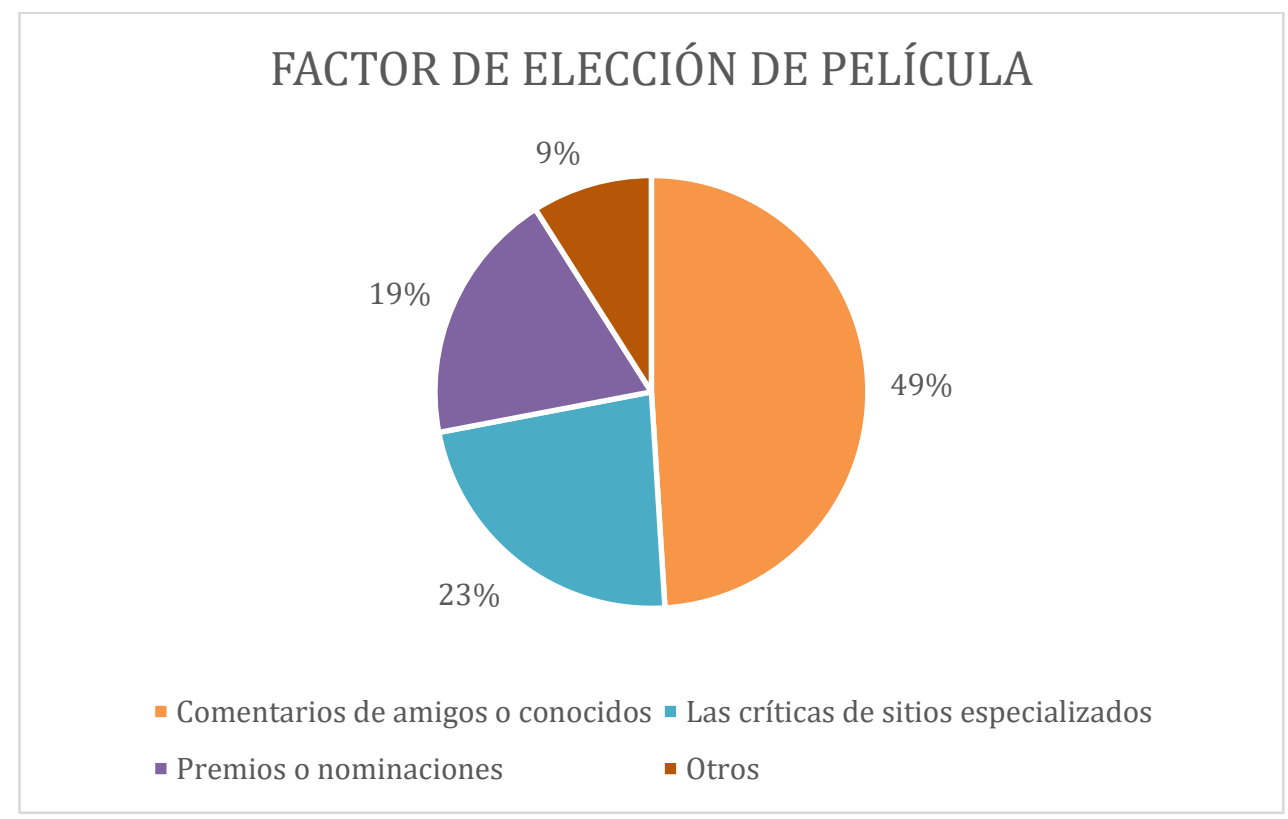

Nota: "El factor que más influye en la elección de la película son los comentarios de amigos o conocidos (49\%), las críticas de sitios especializados (23\%) y los premios o nominaciones importantes de la película (19\%).” (Zegarra, 2019)

Fuente: It Users 


\section{COMPAÑ́́A Y COMODIDAD:}

Figura 3.6

\section{COMPAÑÍA Y COMODIDAD PARA IR AL CINE}

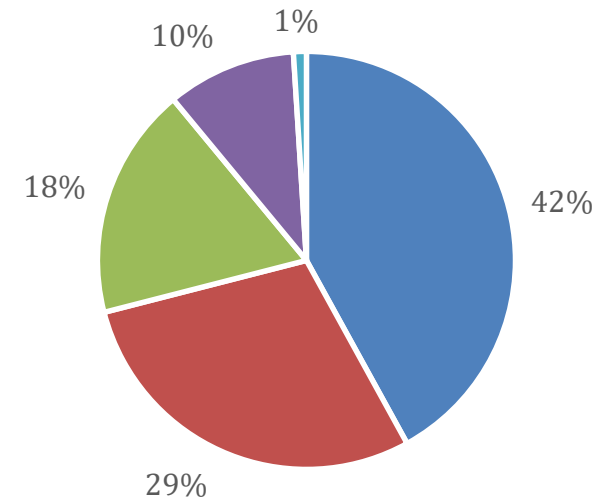

- Familia " Pareja " Hijos " Amigos "Solo

Nota: "Perú se inclina por compartir su salida al cine con la familia (42\%), seguido de la pareja (29\%), hijos (18\%) y amigos (10\%). Tan solo, el $1 \%$ afirma que va solo a cine. Asimismo, el $37 \%$ de los peruanos prefiere una sala de cine que quede cerca de la casa / oficina. El 26\% escoge la sala por el precio de los boletos y el 16\% por la comodidad de la sala." (Zegarra, 2019)

Fuente: It Users 


\section{COMPRAS ONLINE:}

Figura 3.7

\section{COMPRAS DE BOLETOS ONLINE}

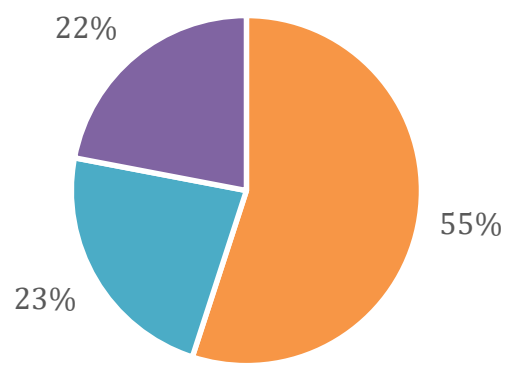

- Desde su celular $\quad$ - Desde la computadora - Otros

Nota: "Cada vez es más común comprar los boletos para el cine desde un dispositivo online. Más del 55\% lo hace desde sus celulares y 23\% desde la computadora." (Zegarra, 2019)

Fuente: It Users

En cuanto a los resultados que nos da esta encuesta, nos parece importante utilizar esta información para plantear la campaña de promoción y saber en qué pilares enfocarnos. Por ejemplo, en cuanto al tema de la elección de la película el 49\% de los encuestados opinan que son los comentarios de amigos y conocidos lo que termina por influir en su decisión por lo que será importante incentivar la campaña de boca a boca y contar con un buen producto. Sobre la compañía, un $42 \%$ va en familia al cine, lo cual está alineado al espíritu de la película, libre de desnudos y lenguaje grosero. Y en cuanto a las compras online más de la mitad de los entrevistados adquiere las entradas a través de su celular por lo que será importante enfocarnos en generar publicidad en las plataformas móviles.

La aparición de Internet y la democratización de los dispositivos móviles han revolucionado sin lugar a duda la experiencia de ir al cine. La revolución digital no solo ha generado nuevas formas de relacionarnos, sino que también ha modificado nuestro acceso y llegada a los diferentes contenidos audiovisuales. Un nuevo perfil de 
consumidor está obligando a productores, realizadores, guionistas y creativos a encontrar nuevas formas de acercarse a las audiencias y lograr comprenderlas en toda su complejidad. Por otro lado, el incremento en cuanto a la oferta de películas nacionales y la aparición de nuevas productoras locales, que han tratado de aprovechar el grado de conexión que se ha comenzado a generar entre contenidos propios y audiencias, está generando también que se produzcan otros cambios importantes en la configuración del perfil del público local: un público que ahora cuenta con una propuesta mucho más variada y continua. 


\section{CAPÍTULO IV: ANÁLISIS DE LA COMPETENCIA}

\subsection{Visión general de la industria}

Sin duda alguna, la oferta cinematográfica, a nivel local, continúa siendo dominada por las grandes productoras internacionales. Dichas productoras trabajan sobre estándares de calidad y presupuestos que nos hablan claramente de una realidad completamente diferente a la nuestra. Sin embargo, y en medio de esta lucha que pareciera recordarnos a las figuras de David y Goliat, las productoras locales han sabido hacerles frente y hacer notar su presencia ante un público local, que ha recibido de muy buen agrado aquellas propuestas con ese "sabor propio" que hace la diferencia con respecto a los contenidos ofrecidos por estas grandes productoras extranjeras.

¿Cómo se presenta el panorama actual para las productoras locales? Lo podemos observar en el siguiente cuadro:

Figura 4.1

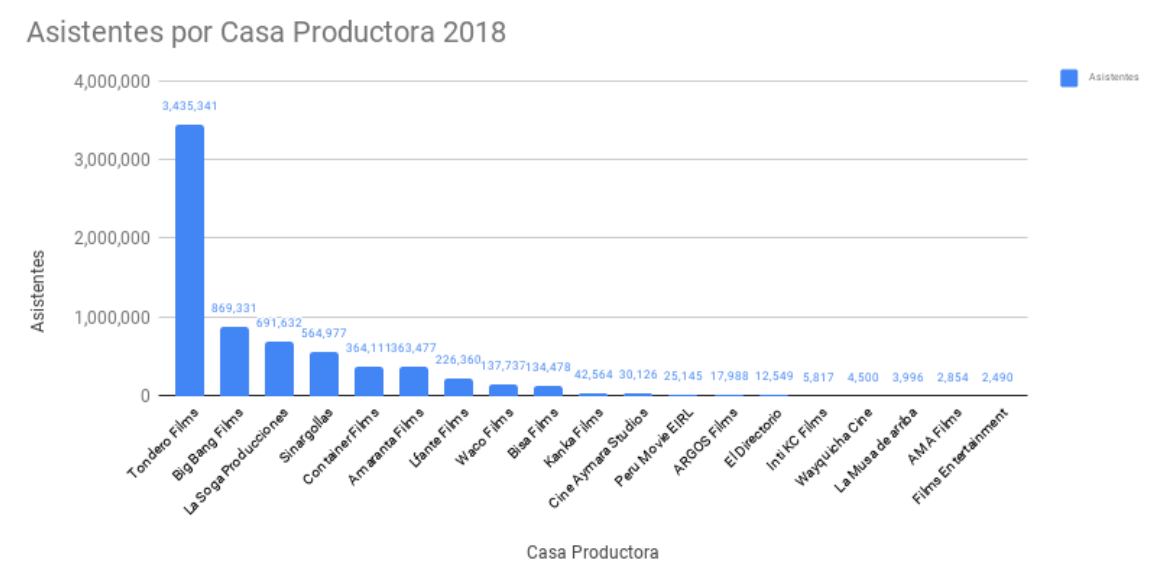

Fuente: Cinencuentro. (Chávez , 2019) 
El comentario que nos da Rodrigo Chávez en su artículo Análisis de la taquilla peruana es bastante alentador con respecto al mercado y a la competencia:

¿Por qué es importante observar este cuadro? Porque en él se encuentra el verdadero gran logro del cine peruano en el 2018. No fue un gran año solo por haber tenido un estreno de más de 2 millones de espectadores, sino porque se consiguió que 9 casas realizadoras amasaran taquillas de 6 dígitos cada una. Es ahí donde radica el verdadero valor de nuestro crecimiento y donde se explican las cifras positivas de este año: el grueso de nuestra taquilla se construyó gracias al acumulado que 9 de las 10 casas productoras más exitosas nos brindaron. (Chávez , 2019)

En el caso del cine es importante comprender que no hay una competencia férrea entre las diferentes productoras sino más bien tener en cuenta que mientras mejor le vaya a una película peruana mejor le ira al mercado en general del cine peruano. El espíritu de tener una competencia sana y de estar apoyándonos mutuamente debería ser la premisa.

\subsection{Número y tamaño de la declaración de los competidores}

En el año 2017 la cartelera comercial peruana arroja un promedio de 250 películas al año. Dentro de este universo, entre el $65 \%$ y el $85 \%$ proviene de Hollywood; el resto son producciones de Inglaterra, Francia y/o España (12\%); poco de cine nacional (9\%) y muy poco de Latinoamérica, Asia y África. (Akamine, 2017)

Estas cifras no hacen más que confirmar el panorama del mercado local en cuanto al comportamiento de la oferta cinematográfica. Durante décadas ha existido y continúa existiendo un claro predominio de producciones cinematográficas producidas en Hollywood; un gran porcentaje de las audiencias locales continúa inclinándose mayoritariamente al consumo de este tipo de contenidos que nos hablan de un modelo de producción, distribución y realización claramente definido. Si bien en los últimos años se ha logrado un mayor nivel de empatía de las audiencias con respecto a las producciones propias, el modelo predominante a nivel global sigue siendo dominado por Hollywood.

Centrándonos a nivel nacional podríamos mencionar los datos que ofrece el Registro Cinematográfico Nacional que contaba en el año 2017 con 380 registros a nivel nacional; 
de los cuales 311 son personas jurídicas y naturales domiciliadas en Lima, que representan el $81.8 \%$ del total de registros, mientras que 69 pertenecen a aquellos domiciliadas en los diversos departamentos del país, incluyendo Callao. Luego de Lima, los departamentos con mayores registros son Cuzco y La Libertad con 10 registros cada uno, y Arequipa con 7 registros. (Dafo, 2016)

Estas cifras arrojan un claro predominio de las producciones que se originan y desarrollan en la capital; aún contrastan fuertemente con las producciones regionales. Así pues, la brecha existente entre ambos polos de producción continúa siendo bastante significativa.

\subsection{Naturaleza de la competencia}

La competencia en esta industria se enfoca principalmente en las características del producto y el marketing. Esto se enfatiza en la publicidad, en comunicados de prensa y en presentaciones de ventas. Los grandes estudios o "majors" mueven una gran cantidad de dinero en torno al marketing de los "blockbuster": promocionando a las grandes estrellas protagonistas o al despliegue de efectos visuales que llenarán la pantalla. Además, manejan diversos medios masivos como anuncios en diarios, trailers en los cines, vallas, etc.

A nivel de país, tenemos una gran variedad de productoras entre Lima y provincias. Generalmente son empresas creadas por los mismos directores para poder sacar adelante su proyecto de película y acceder a fondos, normalmente no tienen tanta continuidad en la producción. También están las empresas que tiene varios rubros de trabajo a parte de la actividad cinematográfica como: publicidad, tv, eventos o espectáculos. Estas tienen cierta continuidad en la producción cinematográfica (Tondero, Big Bang films, Señor Z). 


\subsection{Declaración de calidad}

La calidad es un enfoque principal en la batalla competitiva en esta industria; suele significar, junto con otras variables importantes, el diferencial que puede terminar por convencer a un potencial cliente de adquirir un determinado proyecto o posibilitar su acceso a las salas cinematográficas.

La calidad se transmite a los compradores potenciales mediante los resultados finales ¿Qué tan bueno es el proyecto que se está ofreciendo? ¿Qué tan cercano o lejano se encuentra de sus pares internacionales?

Este factor es determinante al momento de pretender abrir las puertas de mercados extranjeros y nuevas plataformas. Sin embargo, será necesario terminar de establecer normas, marcos legales, jurídicos y tributarios, así como desarrollar una adecuada política de incentivos para ayudar a consolidar y definir los estándares de calidad de las producciones locales. Esto queda claramente demostrado en la siguiente entrevista a Miguel Valladares de Tondero:

Se suele decir que el Perú no tiene la capacidad para desarrollar series de acuerdo a estándares internacionales. ¿Ustedes qué opinan al respecto? Creo que el tema no va por allí, el Perú sí está preparado para exigencias internacionales en series y películas, lo que no tenemos desarrollada es la parte estatal de apoyo hacia la atracción de producciones internacionales. Como pasa en Colombia, que cuando un estudio va a filmar allá, tienen una devolución del $40 \%$ de lo que se invierte en personal técnico colombiano, alquiler de equipos, rental, catering. Además, tienen un $20 \%$ de devolución en logística, hoteles, pasajes, etc. Perú no tiene eso, entonces no podemos competir con otros mercados que ya están abriendo las puertas para convertir a su país en un hub de producción. También competimos con las leyes que tienen países como Chile, República Dominicana, España y muchos otros. Perú no tiene absolutamente nada de eso, nosotros competimos ante países que obviamente crean mayor interés a los estudios grandes para poder filmar en sus territorios. Pero pienso que el talento existe, creo que hay todo lo que necesita un estudio para hacer una buena serie aquí... Lo que no está desarrollada es la estructura legal para que empresas como Tondero o cualquier otra productora podamos ser competentes ante el mundo. (Valladares Vives, 2018) 


\subsection{Competidores principales}

En el mercado local, nuestro principal competidor es Tondero Producciones. Su mayor fortaleza es que tiene varias líneas de trabajo desde ser una empresa representante de actores hasta producir películas, obras de teatro, conciertos y series.

Han tenido éxito en el mercado porque han producido las películas más taquilleras del cine peruano con Asu mare 1, 2 y 3, así como sobrepasar los 2 millones de espectadores cada película.

Datos básicos de la empresa/s competidora/s:

\section{Nombre del competidor: Tondero}

Ubicación: av. Javier Prado Oeste 757, oficina 1805

Años en el negocio: desde el 2008

Número de empleados: De 11 a 50 empleados

Estrategia: La estrategia de Tondero, principalmente, es trabajar con sus representados (actores y artistas) en diversas producciones. Esa es una de sus fortalezas. Otro punto de su estrategia es apelar a la nostalgia en sus producciones.

Posicionamiento de la productora: La productora peruana más exitosa.

Clientes objetivo $\mathbf{N}^{\circ}$ 1: Adultos - Jóvenes

Visto por los clientes: La productora de Asu mare.

Lealtad de los clientes: No hay una lealtad de por sí con la productora, digamos que varía de acuerdo a la producción que saquen. Esto se sustenta con el análisis comparativo de los resultados a nivel de taquilla de sus producciones. Por un lado, estas registran un número importante de asistentes a nivel general; por el otro, se evidencia diferencias bastante grandes y notorias entre proyectos de la misma casa productora (como el caso de Asu Mare con respecto a proyectos como el de Avenida Larco).

Reputación de calidad: Tiene una reputación de sacar producciones de calidad intermedia y de producciones light. Dedicados a la comedia y con actores reconocidos. Si bien el tema de la calidad puede ser materia de discusión y dar origen a diferentes posturas, algo que se debe tomar en cuenta es la percepción que se tiene sobre el perfil de la productora. El estilo que identifica su propuesta está más cercano a lo comercial: desde el mal uso del product placement hasta la estandarización de la propuesta visual, anulando 
muchas veces una propuesta personal del director. En este punto podríamos entrar en discusiones interminables sobre si el criterio de calidad se opone al criterio comercial; es innegable que su propuesta apunta más en esta dirección.

Fortalezas competitivas: Están bien posicionados y sacan producciones continuamente. Debilidades competitivas: La poca calidad de sus producciones.

Producciones destacadas: Asu mare 1, 2 y 3; Locos de amor 1 y 2; A los 40; Guerrero; 7 semillas; Soltera codiciada; El gran león; Magallanes; El elefante desaparecido.

Tiene cuatro divisiones: producciones, espectáculos, representaciones, y distribución y ventas internacionales.

Otras empresas competidoras que han producido continuamente en los últimos años:

Big Bang Films: Herencia, No me digas solterona, Una comedia macabra, etc.

La soga producciones: Rapto, Recontra loca, Django sangre de mi sangre, etc.

\subsection{Oportunidades}

Una gran oportunidad es la nueva ley de cine, aprobada en mayo del 2019 por el Congreso de la República. Dicha ley apunta, principalmente, a potenciar la producción cinematográfica local incrementando los montos de los recursos destinados al sector, se proyecta triplicar dichos montos: de 2.000 UIT se pasaría a 6.000 UIT, lo cual equivale a más de S/. 25 millones de soles.

Otro aspecto por destacar de la nueva ley de cine es el estímulo para donaciones de personas naturales o jurídicas, lo cual permite deducir lo invertido en la declaración de impuesto a la renta.

Además, el hecho de que la nueva ley tiene el espíritu de financiar otros tipos de proyectos audiovisuales, es decir, no se restringe al ámbito de los largometrajes y cortometrajes pudiendo acceder a sus beneficios: contenidos para medios digitales, series, festivales y otros.

Si bien esta nueva ley tiene defensores y detractores, uno de sus aportes innegables es que la producción cinematográfica local tendrá la posibilidad de 
desarrollarse más. Bajo este panorama, un proyecto como El Chalán ve incrementadas sus oportunidades para la obtención de recursos que le permitan pensar no solo en la realización del largometraje, sino también en la posibilidad de desarrollarse bajo otro tipo de contenido.

El mismo género puede convertirse en una oportunidad y un riesgo a la vez, ya que El Chalán es un proyecto cinematográfico que se nutre y bebe directamente de las convenciones propias del género western: un género que, a lo largo de la historia del cine, ha identificado claramente a cinematografías como la norteamericana o la europea; un género que ha pasado casi totalmente inadvertido para la producción cinematográfica local, exceptuando la película “Pueblo viejo” (Perú 2015 / Dir. Hans Matos Cámac). Definiendo de esta manera un terreno virgen y prácticamente inexplorado por guionistas y realizadores audiovisuales locales. Entrevistamos a Beyker Bances ${ }^{5}$, el productor de la película, nos comentó que no tuvieron un plan de promoción establecido y el estreno comercial se vio truncado por las negociaciones con las distribuidoras debido a que no contaban con rostros conocidos en su elenco, esto los dejó prácticamente solos y llevando la película a salas muy específicas en las diversas regiones. Creemos que con una estrategia de marketing bien diseñada podemos generar mucho impacto para que no suceda lo de Pueblo Viejo, además se está planeando convocar a los jóvenes actores como Mayra Goñi y Gustavo Borjas quienes han participado en diversas producciones televisivas y son reconocidos por la audiencia juvenil.

Asimismo, en los últimos años, el western se ha acercado a una nueva generación de público como son los gamers, gracias al exitoso videojuego Red Dead Redemption 2 que, a nivel global ha vendido 23 millones de unidades, lo cual nos parece una excelente oportunidad para la conquista de nuevas generaciones.

Las convenciones definen y configuran claramente la percepción popular que las audiencias tienen del western:

...Recuerdo que, de pequeño, los westerns representaban para mí una incomparable experiencia física y sensorial. Un western era el ruido de los cascos de los caballos en frenética galopada..., el movimiento convulso al accionar el gatillo del rifle de repetición,

5 Observación realizada por Beyker Bances en comunicación personal del 20 de octubre del 2019. 
los chalecos de cuero, los sombreros negros con cintos de plata, el color terroso de las pinturas de guerra de cualquier tribu india belicosa, los caballos bayos, los dibujos sinuosos formados por las dunas arenosas del desierto..., las peleas de salón..., la doma fascinante de un potro salvaje, el tintineo de las espuelas contra las tarimas de madera, el sonido de la ruleta, las lámparas de petróleo, los búfalos en estampida, las emboscadas en angostas cañadas..., la estrella de plata del sheriff, el duelo irremediable en la calle desierta, las tormentas de arena... (Casas, 1994, págs. 11-12)

Es un universo, en el cual somos capaces, como espectadores, de vivir y experimentar nuestros más grandes sueños y fantasías. En eso radica la magia del cine: en transportarnos a esos universos, en los cuales podemos vivir como siempre hemos deseado, identificarnos por completo con sus historias y sus personajes, sentir en carne propia sus penas y alegrías, conocer mundos, experimentar sensaciones inolvidables, independientemente, si estamos transitando por los caminos del drama, la comedia, el fantástico o el criminal. El western no es ajeno para nada a todo esto y, al igual que la mayoría de géneros, ha sabido perdurar y reinventarse sin perder su esencia. Beyker Bances nos menciona que es un género que nunca va a pasar de moda, por ejemplo, menciona a Netflix que produjo un Western - Comedia "The ridiculous 6" protagonizada por el comediante Adam Sandler. ${ }^{6}$

$\mathrm{Si}$ bien algunas propuestas actuales trabajan sobre la base de personajes complejos, antihéroes con conflictos internos, villanos con dimensiones humanas, arquetipos y estereotipos, el proyecto de largometraje El Chalán surge clara y conscientemente tomando como base y referente primordial el cortometraje del mismo nombre realizado hace algunos años. En ese sentido, es necesario comprender que nuestra propuesta se inspira conceptualmente sobre las bases de este primer punto de partida. Consideramos que el perfil de los personajes trabajado para el cortometraje refleja las características, códigos y convenciones de los héroes y villanos propios del género.

Probablemente, como en todo proyecto narrativo, tanto el mundo interno como externo de los personajes podrá ser enriquecido en muchas dimensiones y matices. El hecho de fusionar las convenciones propias de un género foráneo con elementos y tradiciones locales, nos lleva a pensar en posicionar en nuestros espectadores la idea de

6 Observación realizada por Beyker Bances en comunicación personal del 20 de octubre del 2019. 
que los códigos de un género como el western puedan ser verosímiles, coherentes y atractivos dentro de un contexto geográfico e histórico local. El Chalán apostará por capturar la atención de las audiencias y empatizar con ellas con una historia clara y directa, que puede plantear o sembrar ciertos indicios sobre la naturaleza y el pasado de los protagonistas, pero cuyos aspectos serán abordados más adelante cuando el proyecto explore la posibilidad de ampliar sus universos y narrativas en otras plataformas y formatos (como una serie). Consideramos que este será el momento indicado para abordar de manera más compleja la dualidad de los personajes, sus conflictos internos y marcas del pasado, donde terminen de complementar, explicar sus móviles y conductas.

\subsection{Riesgos y amenazas}

Un riesgo es que el género western no termine de atraer a la audiencia local, ya que, si bien el género ha sabido cautivar a diferentes audiencias a nivel global y ha logrado transitar por momentos de gloria a lo largo de la historia del cine, su presencia en estado puro ha sido menor comparativamente hablando con respecto a otros géneros. En un mercado local, en el cual predominan contenidos que sitúan a las historias provenientes de géneros como la comedia, el musical o el drama como las favoritas al momento de medir resultados de taquilla y audiencias, El Chalán deberá enfocar su estrategia de marketing y promoción no solo poniendo énfasis en el hecho de ser uno de los pioneros dentro de un género, sino que debe resaltar el carácter icónico del personaje y de los escenarios además de su elenco.

Otro riesgo son las prácticas que mantienen los cines de no promocionar adecuadamente las producciones nacionales y el retiro apresurado de las salas en favor de los blockbusters extranjeros.

Una gran amenaza es la inestabilidad política y económica. Los escándalos políticos sucedidos desde la caída de PPK, los chats de fuerza popular, el arresto preventivo de Keiko Fujimori, el pedido de adelanto de elecciones de Martín Vizcarra y el cierre del Congreso por parte del Ejecutivo han generado un clima de incertidumbre y cierta desconfianza. 
La inversión de la empresa privada en todos los sectores, y no solo del entretenimiento, se ha visto disminuida en espera de que el clima político se estabilice. Esto afecta a todo posible auspicio o participación de las empresas en las películas.

Estos hechos no afectan directamente a la asistencia de la población al cine; pero, si se agudiza esta crisis, podría afectar de manera significativa al tema económico, por lo cual, la primera reacción será eliminar los gastos que no sean de primera necesidad como los dedicados al entretenimiento y al ocio.

Otra amenaza son los preconceptos que tiene el público con respecto al cine peruano: por un lado, la etiqueta de cine comercial asociado a productos de poca calidad y de poca recordación; por otro lado, tenemos el cine artístico asociado a películas de corte social y con un ritmo lento. Esto podría desanimar al público por ver una película que aspire a tener una buena calidad artística, pero con un impacto comercial. 


\section{CAPÍTULO V: MARKETING}

\subsection{Posicionamiento}

Si tuviéramos que definir las características del posicionamiento que queremos que lleguen el público, estas serían las siguientes:

$$
\begin{array}{ll}
- & \text { Peruano } \\
\text { - } & \text { Heroico } \\
\text { - } & \text { Aventurero } \\
\text { - } & \text { De calidad }
\end{array}
$$

Peruano: porque visualmente los paisajes y la dirección de arte exaltarán con belleza y garbo la iconografía peruana. El contexto peruano, en el cual se ubicará la historia, servirá para proveer al género de cierta atmósfera mística, misteriosa, y al mismo tiempo reconocible, identificable y valorada por la audiencia local, que la percibirá como un plus al interior de ella.

Heroico: porque el personaje de El Chalán es un justiciero: un personaje que tanta falta le hace a una sociedad llena de injusticia y corrupción, un personaje al que puedan admirar. En una coyuntura en la cual la gran mayoría de peruanos percibe en carne propia la falta de valores y el descrédito de muchos sectores de nuestra sociedad, un personaje como el protagonista de nuestra historia contribuirá a generar cierta visión esperanzadora al interior de la misma. 
Aventurero: porque se busca que el público conecte la mitología de la película y las vivencias de los personajes, un universo ficcional que puede desarrollarse en otras plataformas. En todas las épocas y en todas las culturas el ser humano necesita vivir aventuras (por más que estas sean parte de una ficción) que lo hagan partícipe de sensaciones y emociones, que lo alejen de su cotidianidad y de su rutina.

De calidad: porque el estilo visual y sonoro, así como la propuesta narrativa estarán bastante cuidados. Esto marcará la diferencia para el proyecto y tendrá como objetivo principal acercarlo a los estándares de calidad propios de producciones internacionales.

\subsection{Estrategia de promoción}

Son muchos los factores que se deben tomar en cuenta al momento de pensar en la estrategia de marketing más adecuada para un determinado film, esta debe ser pensada y diseñada con el suficiente detalle, cuidado y antelación para tratar de tener los resultados esperados. Según Tamayo y Hendricks "el diseño de un plan de marketing exitoso requiere de un conocimiento especializado del mercado al que la película se dirige, del espectador al que se desea convocar y de las casas de distribución”. (Tamayo \& Hendrickx, 2018, pág. 178)

Al ser El Chalán una propuesta concebida sobre la base y las convenciones propias de un género como el western, se torna imprescindible el hecho de pensar y plantear una estrategia de marketing capaz de generar en el público local la suficiente expectativa e interés por ver el filme.

Es por eso que se buscará generar impacto con la ruptura de un personaje tan icónico como un Chalán colocado en situaciones y en lugares inesperados por el público tratando de generar curiosidad y viralidad. 
Utilizaremos como estructura principal la que nos plantea el embudo de marketing $\mathrm{AARRR}^{7}$, esta se divide en 5 pasos o etapas: adquisición, activación, retención, recomendación y resultados.

La etapa de adquisición. Está estrechamente relacionada con las acciones realizadas para poder visibilizar el proyecto, aquellas acciones destinadas a llamar la atención de nuestro público. Para esta etapa pensamos realizar:

Para esta fase inicial, planteamos principalmente activaciones en público. En este punto, queremos proponer como referentes las activaciones realizadas para el lanzamiento de la serie Cobra $\mathrm{Kai}^{8}$ o el lanzamiento del videojuego de $\operatorname{Mad} \operatorname{Max}^{9}$. En el caso de nuestro proyecto, proponemos medir la reacción del público enfrentándolo al personaje de El Chalán, montado en su caballo, por el tráfico limeño; otra opción sería coreografiar un duelo en plena calle y grabar la reacción de la gente. Otro referente interesante nos parece la estrategia que empleó el proyecto Mad Max, a partir de esta experiencia proponemos asociarnos con una empresa de delivery (tipo Uber eats o Glovo) y ver la reacción de la gente al momento cuando llega El Chalán en su caballo entregando algún pedido.

- Proponemos realizar una campaña de intriga con afiches tipo "Se busca" o "Se ofrece recompensa" (al estilo del lejano oeste) con la imagen del antagonista de la película, esto generará cierta sensación de misterio con respecto al proyecto originando una mayor expectativa por conocer mucho más sobre él.

- Se coordinarán entrevistas con blogs especializados en cine: tales como Cinencuentro, Cinesmero o Fandango, para que los cinéfilos se puedan ir

\footnotetext{
${ }^{7}$ El modelo AARRR fue creado por Dave McClure, fundador de la incubadora "500 Startups" este es un derivado del modelo AIDA (Atención - Interés - Deseo - Acción) que Elías St. Elmo Lewis creó en 1893. Se basa en la psicología de la publicidad y está dirigido principalmente al análisis de herramientas de marketing offline y fue muy popular en la década de 2000. Sin embargo, debido al rápido desarrollo de la industria digital, hubo una necesidad de crear un modelo diferente, centrado en la venta online.

${ }^{8}$ Link para ver las activaciones realizadas para el lanzamiento de la serie Cobra Kai: https://www.youtube.com/watch?v=cgIbzjjbdw8\&feature=youtu.be

${ }^{9}$ Link para ver el lanzamiento del videojuego de Mad Max:

https://www.youtube.com/watch?v=L42i2LlevXY
} 
informando sobre el proyecto. Se re direccionará al público a las páginas oficiales presentes en las diferentes plataformas.

- Proponemos la realización de un 1 teaser tráiler y 3 tráileres principales (divididos a lo largo de 3 meses antes del estreno de la película). Estos tráileres se difundirán principalmente en cines, ads en Youtube y buscará que generen respuesta en diferentes blogs de cine.

- Diseño de afiches y paneles de la película, en la cual destaquen los elementos peruanos.

Ads de Facebook e Instagram.

- Ir a convenciones de cinéfilos y Geeks para promocionar la película.

- Ir a los diversos eventos de caballos de paso para hacer promoción.

Junkets: entrevistas para todos los medios, prensa, televisión, radio, internet con los protagonistas del filme.

- Publicity: publicidad no pagada y notas de prensa (se considerará un agente de prensa).

- Conferencia de Prensa.

- Será importante también tomar en cuenta el material gráfico y audiovisual para estas salas: la presencia de afiches impresos, afiches digitales para monitores, displays de cartón, standees (en sus diferentes variantes), banderolas, material brandeado (como las cajas para la canchita), adquieren relevancia para recrear el universo del film en las salas.

- Avant premiere (alfombra roja del preestreno). 
La etapa de activación. Esta etapa tiene que ver con las acciones realizadas para poder brindar información en detalle y lograr que el público se interese por el proyecto. Para esta etapa proponemos realizar:

- Páginas oficiales en las diferentes plataformas digitales creadas desde el inicio de la producción de la película: Sitio Web, en el que se publicará el contenido oficial de la película; Fan Page de Facebook, en el cual se irá actualizando constantemente información de la película (por ejemplo, si queda seleccionada para algún festival o si gana algún premio); Instagram, en la cual se colgarán fotos de detrás de cámara del rodaje y se realizarán Instagram Stories con los actores protagonistas.

- Electronic press kit o EPK (entrevistas y escenas de los actores principales, así como del director y parte del equipo técnico, locaciones elegidas en el territorio peruano, etc.).

La etapa de retención. En esta etapa, proponemos llevar a cabo acciones para lograr que el público regrese a ver el contenido. Planteamos las siguientes acciones:

- Crear un canal de Youtube de Nostradamus Producciones, en el que se irá publicando diversos contenidos: un video diario del rodaje de la película, diversos tutoriales o reviews de equipos utilizados, entrevistas a los involucrados en el proyecto, el corto en el que se basa la película, etc. Un contenido que conecte con el público y que sea útil para cualquier producción de Nostradamus.

- Publicar cada cierto tiempo variantes de las gráficas de la película, en las que se invite a artistas reconocidos para que hagan su propia versión del afiche. Por ejemplo, Cherman, un ilustrador y diseñador gráfico ${ }^{10}$.

\footnotetext{
${ }^{10}$ Link para conocer sobre el ilustrador y diseñador gráfico Cherman: https://andina.pe/agencia/noticiagerman-kino-ganoza-cherman-prefiero-viajar-por-peru-tener-mi-selfie-europa-499414.aspx
} 
Igualmente trabajar este tipo de gráfica con alumnos universitarios o escolares.

- Proponemos también un concurso abierto (al público en general) para que realice sus propios diseños para los afiches alternativos de la película con el objetivo de hacer partícipe a la comunidad. Los afiches seleccionados podrán acompañar al filme a algunos de los festivales seleccionados.

La etapa de recomendación. Esta etapa está vinculada con las acciones realizadas para lograr que el público recomiende el contenido. Para esta etapa se proponen las siguientes acciones:

- Concursos y sorteos relacionados a compartir la información del proyecto o algún contenido particular como el tráiler.

Crear algún tipo de reto para el público y que pueda formar parte de la película, como explotar la peruanidad o la figura heroica de El Chalán.

- Trabajar con influencers relacionados al cine para que recomienden la película a sus seguidores.

- Realizar sorteos de muñecos de acción o estatuas realizadas en las impresoras 3D de la Universidad de Lima - FABLAB (Laboratorio de fabricación).

- Unas semanas antes del estreno se invitará a un grupo de influencers y celebrities a vivir una experiencia relacionada a la película con el fin de que lo mencionen a sus seguidores. Esta experiencia estaría ligada al lugar de filmación y al caballo de paso. Por ejemplo, si se graba en Trujillo, se le invitaría a una excursión en caballo de paso y organizar diversas actividades relacionadas al tema de El Chalán para luego entrevistarse con los actores y el equipo. Esta acción podría estar auspiciada por el 
municipio de la localidad donde se lleve a cabo o también por empresas relacionadas al turismo.

La etapa de resultados. Tiene que ver con qué es lo que queremos lograr con todas estas acciones. Está etapa está definida por los siguientes objetivos:

- En Youtube: lograr al menos 100 mil vistas en 1 año desde que comience el rodaje.

- En Facebook: lograr al menos 500 mil likes en 1 año desde que comienza el rodaje.

- En la taquilla local: llegar a la cifra de 300 a 500 mil espectadores durante el período de exhibición.

Si tuviéramos que preguntarnos ¿En qué medida contribuirá este proyecto a definir la personalidad de una productora como Nostradamus Producciones? podríamos ensayar algunas respuestas:

- Servirá para establecer en el público y en los posibles financistas la idea de que Nostradamus irrumpe en el mercado local con una visión y propuesta diferente. Consideramos que esto será de vital importancia para diferenciarnos (desde un inicio) del resto de productoras, que operan a nivel local, esto ayudará a ir definiendo una personalidad a nivel de empresa y a nivel de propuesta artística.

- Por otro lado, al abordar un género casi inexplorado y poco recurrente en la producción y realización cinematográfica local, estaremos sentando las bases para posicionarnos como una productora de contenidos audiovisuales que nace completamente dispuesta a descubrir otros caminos. 
- Este será el punto de partida para ampliar el universo del personaje en otras plataformas.

Esta estrategia de marketing debe ser trabajada y ejecutada con el suficiente tiempo de anticipación y como parte del concepto general que define al proyecto, aproximadamente, esto abarca un periodo de 6 meses.

\subsection{Plan de ventas}

Será de vital importancia para un proyecto como El Chalán diseñar y ejecutar un plan de ventas que permita generar expectativa tanto a nivel internacional como a nivel local.

En cuanto al plan de ventas, consideramos necesario establecer una suerte de recorrido o itinerario para la película que permita ir consiguiendo objetivos a largo, mediano y corto plazo. En este sentido, proponemos un plan de ventas que se lleve a cabo sobre la base de los siguientes vértices y que se desarrolle a partir de un cronograma coherente y lógico. Este plan de ventas abarcaría estratégicamente los siguientes escenarios: festivales, cartelera y plataformas.

\subsubsection{Festivales}

Será importante establecer un calendario de asistencia a festivales que permita a El Chalán tener presencia y participación en los festivales más representativos de la región, así como en festivales de Europa que suelen dar acogida a producciones latinoamericanas. Esto permitirá que llegue a la fecha de su estreno con un importante recorrido por estos eventos.

En los últimos años, las producciones cinematográficas latinoamericanas han ido cobrando mayor notoriedad en festivales internacionales a nivel global. Muchos de estos festivales se han convertido en la puerta de entrada no solo para la exhibición de proyectos latinoamericanos, sino también para establecer nexos, vínculos y contactos que 
han posibilitado consolidar coproducciones $\mathrm{y}$ acceder a importantes fuentes de financiamiento para diversos proyectos.

Si damos una mirada a la programación de los principales festivales cinematográficos realizados en Europa, podemos observar una presencia bastante importante y relevante con respecto a la participación en competencia y exhibición de proyectos latinoamericanos. $^{11}$

Será necesario, en esta primera etapa, priorizar aquellos eventos que se acerquen más a los objetivos que persigue un proyecto como El Chalán. La asistencia a dichos festivales dependerá, en gran medida, de temas presupuestales, financiamiento y fechas de programación. Sin embargo, nuestro objetivo es lograr que El Chalán pueda tener un importante recorrido a lo largo de estos festivales y en meses previos a su estreno local, pues estamos convencidos de que esto será más que beneficioso para el proyecto con respecto a su imagen y reconocimiento.

El poder establecer una fecha de estreno en salas locales luego de que el filme haya podido ser apreciado en dichos festivales servirá tanto para la campaña de marketing y promoción, como para generar expectativa en la audiencia.

Dentro de los festivales más representativos de la región se plantea un recorrido por los siguientes:

Festival de Cine de Bogotá (BOGOCINE): evento cinematográfico internacional más importante de Colombia, fundado en 1984 y con más de 33 años de trayectoria. Premia a películas nacionales y producciones de países andinos, el Caribe, Sudamérica, España, Francia, África y el Pacífico. Suele realizarse en el mes de octubre.

- Festival de Cine de Lima PUCP (Perú): presenta lo mejor del cine latinoamericano y del mundo. Lleva cerca de 22 años de trayectoria y suele realizarse en el mes de agosto.

\footnotetext{
${ }^{11}$ En el siguiente link hay un artículo con información relevante de uno de los últimos festivales en Europa y sobre la participación en competencia y exhibición de proyectos latinoamericanos: https://www.latamcinema.com/londres-sitges-y-helsinki-el-cine-latinoamericano-se-celebra-en-europa/
} 
- Santiago Festival Internacional de Cine (SANFIC) (Chile): es una plataforma cinematográfica, cultural, artística, industrial, educativa. Suele programarse en el mes de agosto y lleva cerca de 12 ediciones.

- Festival Internacional del Nuevo Cine Latinoamericano (Cuba): es uno de los festivales de mayor prestigio, su programación acoge a producciones provenientes de todas partes del mundo y suele programarse en el mes de diciembre.

- Festival Internacional de Cine de Cartagena (FICCI) (Colombia): lleva alrededor de 56 ediciones con el objetivo de promover la producción y realización de filmes latinoamericanos e iberoamericanos. Suele programarse en el mes de marzo.

\section{Buenos Aires Festival Internacional de Cine Independiente (BAFICI)}

(Argentina): es el evento más grande y prestigioso para el cine independiente de América Latina. Suele programarse en el mes de abril. (Blum, 2016)

Por otro lado, a nivel de Europa, es importante también pensar en algunos de los festivales que puedan servir de impulso a un proyecto como El Chalán.

A lo largo de las últimas décadas, los grandes festivales de Europa como Venecia, Cannes, San Sebastián, Berlín se consolidaron como las primeras puertas de entrada para las producciones latinoamericanas. No obstante, conforme el cine latinoamericano ha ido ganando prestigio y presencia en estos eventos, han surgido otros escenarios que también sería importante tomar en cuenta para el itinerario del proyecto.

Dentro de este panorama, nos parecen bastante interesantes las siguientes opciones:

- Festival de Biarritz (Francia): este festival se ha convertido en un evento de referencia para el cine latinoamericano. Lleva alrededor de 22 ediciones y acoge largometrajes, cortometrajes y documentales.

- Festival Latinoamericano de Flandes (Amberes-Bélgica): es uno de los festivales más jóvenes, pero con mayor futuro. Lleva cerca de cinco ediciones.

- Festival Lakino (Berlín-Alemania): se ha convertido en un punto de encuentro y discusión para cineastas latinoamericanos. Lleva alrededor de cuatro ediciones. 
- Festival Cinelatino (Toulouse-Francia): lleva alrededor de 26 ediciones y es uno de los más importantes del continente.

- Festival de Cine Latinoamericano de Trieste (Italia): lleva alrededor de 28 ediciones, es uno de los más grandes a nivel de Europa y acoge proyectos de películas, video y televisión.

- Festival de Cine Iberoamericano de Huelva (España): lleva más de tres décadas de trayectoria y es uno de los de mayor prestigio. (Blum, Jonathan Blum, 2016)

Mención aparte, merece la posibilidad de poder asistir a un festival que nos pareció sui generis. Se trata del Almería Western Film Festival (AWFF).

Este festival surge en el 2011 con el objetivo de revalorar el legado cinematográfico de un género como el western. Su desarrollo está muy vinculado a los atractivos turísticos de la provincia situada en Andalucía, donde se lleva a cabo y, durante muchos años, se convirtió en una de las locaciones más importantes para las realizaciones de filmes propios del Spaghetti western.

Durante estos años, el AWFF ha ofrecido a los amantes del western proyecciones cinematográficas internacionales y se ha convertido en un punto de encuentro para profesionales, amateurs y público en general, lo cual le otorga una personalidad bastante peculiar al evento. Se ha convertido en una cita importante para todos los interesados en indagar sobre el género western. Su programación tiene como objetivo presentar las nuevas tendencias del género a nivel mundial y dar cabida a diferentes formatos: largometrajes, cortometrajes y documentales entre otros.

Ha logrado una repercusión significativa: su difusión en medios de comunicación ha superado los 2 millones de seguidores en radio y televisión, más de 134 millones de contactos en prensa escrita y online, y un alcance que supera los 360,000 contactos en redes sociales, según el informe elaborado por la consultora Kantar Media, encargada de medir el impacto del evento. En cuanto a su presencia en Internet, durante la última edición se registraron un total de 52,812 visitas únicas a páginas procedentes de España, Estados Unidos, Francia, Alemania, Italia, México entre otros. ${ }^{12}$

\footnotetext{
${ }^{12}$ La información del Almeria Western Film Festival se puede encontrar en: http://www.almeriawesternfilmfestival.es/es/ediciones-anteriores/
} 
Por todas estas razones, nos pareció una ventana interesante para el recorrido de El Chalán.

\subsubsection{Cartelera}

Será importante tener claramente definido el tipo de circuito en cuanto a las salas de exhibición que se va a priorizar. Más que proponer un número exacto de salas o pantallas para la exhibición de El Chalán, nos parece prioritario pensar en el tipo de modelo o estrategia por seguir.

Como explican Augusto Tamayo y Nathalie Hendrickx:

El dónde y cuándo exhibir una película dependerá de la estrategia de lanzamiento diseñada para ella...el mercado cinematográfico peruano funciona de manera similar al de otros países de la región, aunque en proporciones diferentes. Estos son algunos ejemplos de circuitos de exhibición en Lima Metropolitana: 1. Circuito A (art house) conformado por un número reducido de pantallas de cine (entre 4 y 10) ubicadas en las siguientes zonas de Lima: Miraflores, San Miguel, San Isidro, Surco, San Borja; 2. Circuito B conformado por entre 20 y 45 salas de cine. Puede incluir las del Circuito A más las pantallas de cine de Jesús María, San Miguel, el centro de Lima, Ate Vitarte, Los Olivos, Santa Anita, Breña, Surquillo, San Borja, Callao, Chorrillos, así como salas de algunas provincias; 3 . Circuito $\mathrm{C}$ conformado por entre 80 y 150 salas de cine suele ser para películas de alta recaudación o blockbusters. se suman a las de los circuitos A y B las pantallas de los Conos Norte y Sur, Rímac, Independencia, El Agustino, San Juan de Lurigancho, Comas, San Martín de Porres y las de todo el Perú, en un estreno simultáneo. (Tamayo \& Hendrickx, 2018, págs. 87-88)

En el caso del interior del país, consideramos que sería importante poder tener presencia, al momento del estreno, en los siguientes departamentos: Piura, Trujillo, Arequipa, Cusco, Tacna, Pucallpa.

Igualmente será importante definir la forma de explotación comercial que se desea establecer para el filme: explotación lenta, explotación media o explotación rápida. En el caso de El Chalán, consideramos optar por la modalidad de explotación media, la 
cual implica el circuito: dirigir la exhibición hacia puntos estratégicos, contemplar de 25 a 50 copias distribuidas entre Lima y algunas ciudades importantes del país (como las mencionadas anteriormente) y sin saturar.

Asimismo, se piensa comprometer al elenco y a parte del equipo de realización para que se haga presente en las funciones, sobre todo en las primeras semanas para establecer un contacto más cercano y directo con el público, y crear expectativa a partir del boca a boca generado por el público asistente.

La estrategia para el estreno nacional del El Chalán deberá tomar en cuenta estos aspectos del market share de las cadenas de cines:

Figura 5.1

\section{Market Share Industria Exhibición de Películas Diciembre 2018}

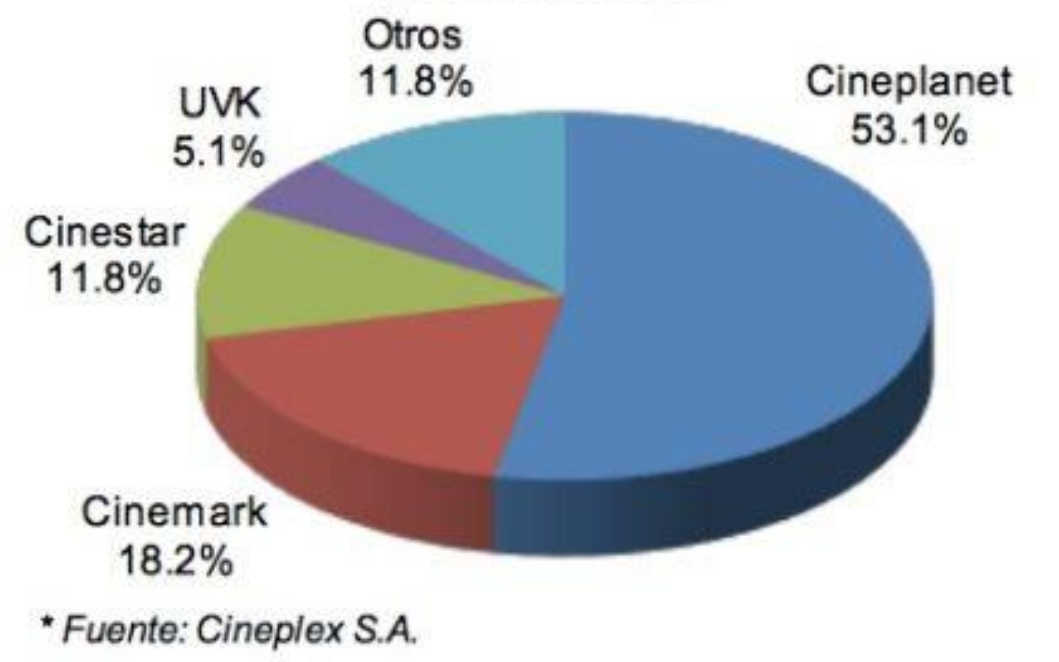

Fuente: Revista Ganamás (Ganamás, 2019)

Al ver el market share una opción sería tratar de lograr un acuerdo con la cadena Cineplanet para exhibir en exclusividad con ellos ya que tienen más del $50 \%$ de salas y permitir de que la película se mantenga más tiempo en salas. 
El estreno de El Chalán estaría previsto luego de que el filme haya realizado su recorrido por algunos de los festivales ya mencionados. En un primer momento, se pensó en la posibilidad de estrenar en Fiestas Patrias, que es una fecha importante dentro del calendario de la cartelera cinematográfica local, pero se ha optado por proponer los meses de agosto o septiembre para evitar un enfrentamiento directo y desigual con los estrenos de los grandes blockbusters que se suelen dar en esta fecha. Según Tamayo/ Hendrickx:

...la fecha de estreno es igualmente importante para colocar el filme en su posición competitiva más fuerte. No se trata de elegir aquella en la que estadísticamente va más público al cine en general, sino de determinar la más adecuada para la película en particular. (Tamayo \& Hendrickx, 2018, pág. 179)

Será importante también, para definir la fecha de estreno, consultar previamente el film competitive (el calendario de estrenos de películas en la ciudad) para tener claramente mapeados los estrenos importantes, esto se definirá mejor cuando esta fecha esté cerca.

\subsubsection{Plataformas}

Con respecto al tema de plataformas, se propone un recorrido para El Chalán que tenga como objetivos principales extender el tiempo de vida del filme y llegar a un público más amplio y mucho más allá de las salas cinematográficas.

Una vez culminado el período de exhibición en salas cinematográficas locales, se tiene proyectado hacer llegar el filme a las siguientes plataformas:

- Televisión por cable tradicional. Nos interesa de sobremanera poder concretar la venta del filme con algunos operadores de cable. Esto nos permitirá conseguir una mayor exposición, sobre todo, a nivel internacional y en otros mercados.

- Aerolíneas y empresas de transporte terrestre. Consideramos que este también es un nicho de mercado interesante para lograr llegar a otro tipo 
de audiencias. En este caso, nos interesa poder llegar a aquellas empresas que realizan recorridos tanto a nivel local, como internacional.

- Plataformas de streaming. El Chalán es una propuesta atractiva para cualquiera de las plataformas de streaming actuales. Nuestro objetivo es poder llegar a interesar en la adquisición del proyecto a una plataforma como Netflix, que cuenta ya con varias películas peruanas como parte de su oferta. Adicionalmente, es nuestra intención generar a partir del largometraje un contenido adicional (serie). Este contenido podrá tener más de una temporada dependiendo de la acogida de la audiencia.

- Televisión de señal abierta internacional

- Televisión de señal abierta local. A nivel local, nos interesa poder trabajar con América Televisión. Esta casa televisora cuenta al interior de su programación con un ciclo de películas nacionales llamado Taquilla Nacional que normalmente es programado los fines de semana durante los meses de verano, que es la temporada en la cual descansan sus producciones. Este ciclo de películas está posicionado de alguna manera en el público televidente pues viene emitiéndose desde hace aproximadamente tres años, lo cual sería beneficioso para el filme.

- Universidades, institutos vinculados al mundo del audiovisual, foros, organismos estatales, salas culturales, etc. Consideramos que esta ventana también conforma diversos escenarios de interés para la exhibición, discusión, conversación y debate sobre "El Chalán" y la experiencia de haber realizado un proyecto de esta naturaleza.

- Venta en DVD o Blu-ray. Librerías, supermercados.

Si bien nos interesa poder transitar por todas estas plataformas, pensando directamente en El Chalán, es necesario poner también el énfasis en lo que esto puede ir representando para una empresa como Nostradamus Producciones en el mediano y largo plazo, ya que la experiencia que se recoja en cada uno de los proyectos emprendidos 
servirá para que se vaya consolidando como empresa y para ir corrigiendo y ajustando errores para nuevos proyectos.

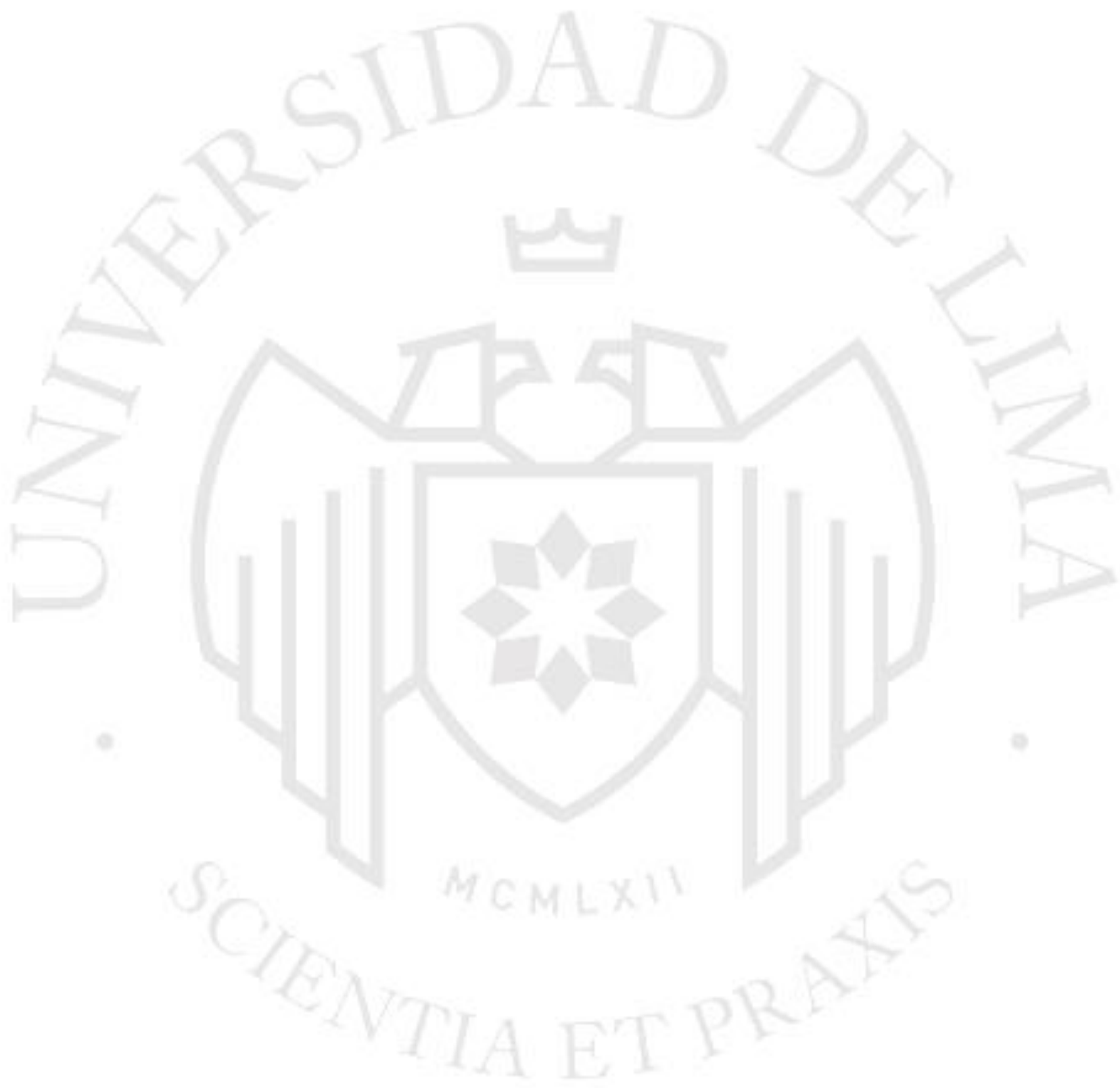




\section{CAPÍTULO VI: OPERACIONES}

6.1 Personal Técnico, de Realización y Producción (jefes de áreas):

- Director: Alberto Matsuura

- Productor: César Arana

- Guionistas: Alberto Matsuura / Bismarck Rojas

- Director de fotografía y cámara: Jorge Cerna

- Compositor: Enrique Alberto Haro

- Editor: Julio Wissar / Sandra Rodríguez

- Director de arte: Giuliana Torres

- Sonidista: Millie Wissar

- Vestuario: Leslie Hinojosa

- Styling: Laura Quijandria 
DIRECTOR: ALBERTO MATSUURA SONODA (LIMA - 1977)

Egresado de la Facultad de Comunicación de la Universidad de Lima con el grado de licenciado. Actualmente, se desempeña como docente de esa casa de estudios. Tiene una amplia experiencia en diversos cargos entre los que se encuentra: dirección, guion, edición, sonido principalmente en cortometrajes y videoclips. El Chalán sería su ópera prima en largometrajes.

\section{Filmografía:}

\section{Director}

- “El Chalán” (Cortometraje - 2006)

- "Core Business" - Posgrado Ulima (Micro Programa Facebook - 2018)

- "Harumy Sings" - Videoclips (Canal de Youtube Harumy Ortiz - 2018)

- "Se puede pedir perdón" - Videoclip (Cantante Martín Haro - 2010)

- "Pequeñas cosas" - Videoclip (Cantante Martín Haro - 2010)

"Buena estrella" - Videoclip (Cantante Caroline Cruz - 2012)

\section{Guionista}

- “El Chalán” (Cortometraje - 2006)

- “Se puede pedir perdón” - Videoclip (Cantante Martín Haro - 2010)

- "Pequeñas cosas" - Videoclip (Cantante Martín Haro - 2010)

“Buena estrella" - Videoclip (Cantante Caroline Cruz - 2012) 


\section{PRODUCTOR: CÉSAR ARANA DIAZ (LIMA - 1964).}

Egresado de la Facultad de Comunicación de la Universidad de Lima con el grado de licenciado. Actualmente, se desempeña como productor de América Televisión y como docente de la Universidad de Lima. Tiene una amplia experiencia en el área de producción.

\section{Filmografía:}

\section{Productor}

Cumbia Pop (TV Serie - 2018)

Amores que matan (TV Serie - 2016 / 2017)

Solamente Milagros (TV Serie - 2015)

Rita, yo y mi otro yo (TV Serie - 2014)

- Rita y yo (TV Serie - 2013)

- Fusión Gourmet (Canal gastronómico - 2011 / 2012)

Entre otros. 


\section{DIRECTOR DE FOTOGRAFÍA: JORGE CERNA LOLOY (LIMA - 1966)}

Egresado de la Facultad de Comunicación de la Universidad de Lima. Trabajó por muchos años en la productora Cinesetenta en diversos proyectos publicitarios. Actualmente, se encuentra laborando y desarrollando su carrera como director de fotografía independiente.

\section{Filmografía:}

\section{Director de fotografía en Largometrajes}

"La casa rosada" de Palito Ortega

"Sueños de Gloria", de Alex Hidalgo.

"Buscando a Fitzcarraldo" Largometraje documental de Bryan Jacobs.

- "Camino a la Hoyada" Largometraje documental de Andrès Cotler.

- "Cines de video" Largometraje documental (en proceso) de Wari Gálvez.

- Entre otros.

\section{Director de fotografía en Cortometrajes}

- "El Chalán” - de Alberto Matsuura

- "Corazón delator" - de Claudio Ceino

- " $2 x 5 "$ - de Valentín Vergara

- "Circulo vicioso" - de Andrés Vernal y Heyly Delgado

- "Última función" - de Roberto Flores

- Entre otros 


\section{GUIONISTA: BISMARCK ROJAS SALAZAR (LIMA)}

Egresado de la Facultad de Comunicación de la Universidad de Lima. Tiene una amplia experiencia laborando como director, camarógrafo, post productor y guionista, principalmente, en cortos y videos institucionales. Actualmente, es gerente general de su productora Veintiuno films y está en el desarrollo de su ópera prima "Pirú".

\section{Filmografía:}

\section{Director}

"Pirú" - Largometraje en desarrollo

“Oh, sweet Jesús! Please, no” - Piloto de serie web (en desarrollo - 2019)

"D.A.D" - Piloto de serie (Por estrenarse - 2019)

- "Instantes" (Serie web documental - 2016)

- "Saxra" (Cortometraje - 2014)

\section{Guionista}

- "Pirú" - Largometraje en desarrollo

- "Saxra" (Cortometraje - 2014) 


\subsection{Personal Artístico:}

- José Luis Ruiz (El Chalán)

- $\quad$ Reynaldo Arenas (El Cuto)

- $\quad$ María Angélica Vega (Claudia)

- $\quad$ Mayra Goñi (La peque)

- $\quad$ Gustavo Borja (Puñal)

El casting se ha pensado y diseñado considerando las diferentes audiencias (a nivel de edades). Si bien la trama o narrativa principal recae en los personajes adultos o "maduros" no se deja de lado la participación de personajes jóvenes o "adultos jóvenes" que refresquen los universos narrativos y conflictos propios de los mismos. Estamos completamente convencidos que ambas propuestas se complementan perfectamente.

Como señalamos en la propuesta de casting, los personajes principales interpretados por actores de mayor trayectoria y de mayor edad como José Luis Ruiz, María Angélica Vega y Reynaldo Arenas estarán rodeados por actores jóvenes como Mayra Goñi y Rodrigo Borja que han sabido calar, a pesar de su corta trayectoria, en los gustos del público. La idea es que junto a estos "actores pilares" o "personajes ancla" se sumen otros personajes más jóvenes que complementen la propuesta narrativa. Algunos proyectos recientes como la película "Django: sangre de mi sangre" han apostado por esta propuesta con resultados interesantes a nivel de audiencias.

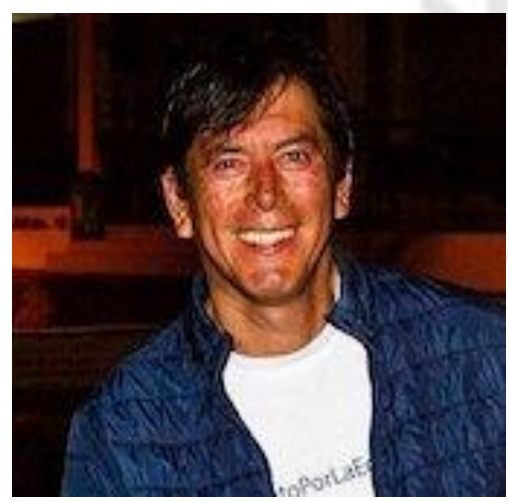

JOSE LUIS RUIZ BARAHONA (LIMA - 1969)

Actor de reconocida trayectoria en cine, teatro y televisión. Comenzó su carrera actoral en el año 1990 en la telenovela Natacha y tuvo su primer rol protagónico en el cine con "Bajo la piel" de Francisco Lombardi (1996). Fue protagonista del cortometraje El Chalán y volvería a repetir el personaje en el largometraje.

\section{Filmografía:}




\section{Largometrajes}

- “Bajo la piel” (1996)

- “Vidas paralelas” (2008)

- "El premio" (2009)

- Entre otros

\section{Cortometrajes}

- “Rayas" (2004)

- "Fundido a negro" (2005)

- "El Chalán” (2006)

"Sheut" (2018)

- Entre otros

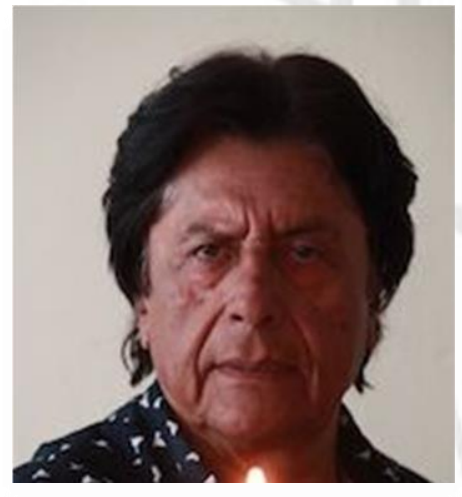

\section{REYNALDO ARENAS (CUSCO - 1944)}

Destacado actor de teatro, cine y televisión con 50 años de carrera artística. Mayormente, se identifica como un actor de teatro, pero uno de sus roles más destacados y recordados es en el cine es el de Túpac Amaru II en "Túpac Amaru” (1984).

Filmografía:

\section{Largometrajes}

“Un mulato llamado Martín" (1975) 
- “Túpac Amaru” (1984)

- “El señor de Sipán” (Documental 2007)

- "Perro Guardián” (2014)

- Entre otros

\section{Cortometrajes}

- “El Chalán” (2006)

- “Ayaymama" (2016)

- "Psychotria" (2018)

- Entre otros

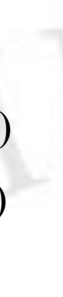

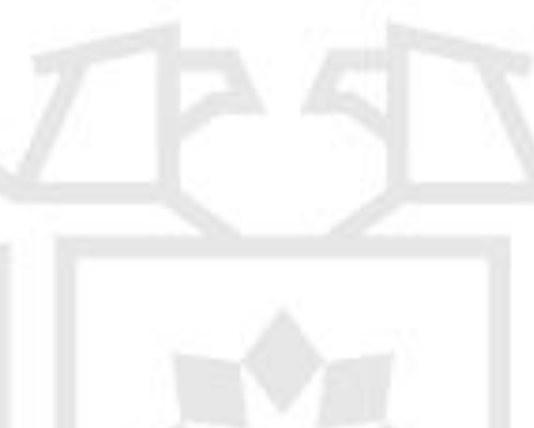

MARIA ANGÉLICA VEGA (LIMA - 1969)

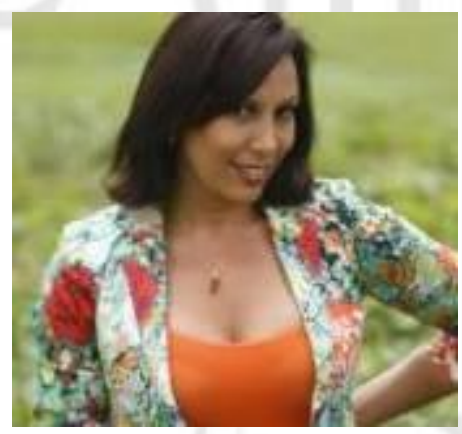

Actriz de reconocida trayectoria en el cine, teatro y

la televisión. En televisión destacó por sus roles en las miniseries "Tatán" y "Los de arriba y los de abajo". En el cine tuvo su primer protagónico en la película "Asia, el culo del mundo" (1992).

\section{Filmografía:}

\section{Largometrajes}

- “Asia, el culo del mundo" (1992)

- "Bolero de noche" (2011)

- “La deuda" (2015)

- Entre otros 


\section{Cortometrajes}

- "El pecador de los 7 mares" (1992)

- "Fast Love" (1998)

- "El Chalán" (2006)

- Entre otros.

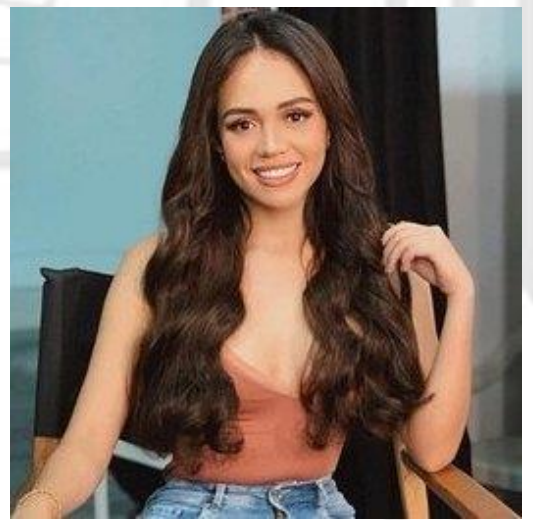

\section{MAYRA GOÑI (LIMA - 1992)}

Actriz, empresaria, influencer, Youtuber y cantante peruana. Debutó en televisión en el 2007, como protagonista en Yuru: La princesa de la selva (2007).

\section{Filmografía:}

\section{Televisión}

- “Yuru, la princesa amazónica” (2007)

- “Magnolia Merino” (2008)

- “Eva” (2011)

- “Conversando Con La Luna” (2013)

- “Locura de amor" (2014-2015)

- “Ven, baila, quinceañera” (2015-2018) 
- “Los Vílchez” (2019)

- Entre otros.

\section{Largometrajes}

- "El buen Pedro" (2012)

- "Perro Guardián" (2014)

- “Av. Larco" (2017)

- “Locos de amor 2" (2018) 


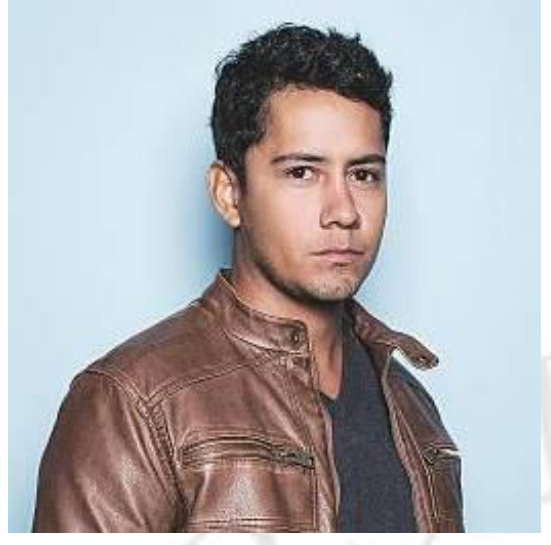

\section{GUSTAVO BORJA (LIMA - 1989)}

Actor peruano conocido por su trabajo en películas, telenovelas y series dramáticas. Se destaca por su papel de Johnny Torrejón en la serie de televisión Los Vilchez del 2019. También es conocido por haber interpretado a Sebastián en la película $E l$ Soñador del 2016.

\section{Filmografía:}

\section{Televisión}

“Mi amor el Wachiman” (2012)

- “Al fondo hay sitio”. (2014)

- “Los Vilchez” (2019)

\section{Largometrajes}

- “F-27: The Movie” (2014)

- “El Soñador" (2016) 


\section{CAPÍTULO VII: FINANZAS}

7.1 Presupuesto de la película $E l$ Chalán (según modelo Dafo) 


\section{PRESUPUESTO LARGOMETRAJE "El CHALÁN"}

Este presupuesto es referencial y modificable. Es posible añadir o suprimir filas si se considera necesario. Puede agregar filas encima de la separación en negro y/o dejar en blanco los ítems que no requiera el Proyecto. Este formato contiene fórmulas prestablecidas, por favor tenga cuidado al completarlo para no afectar el resultado total.

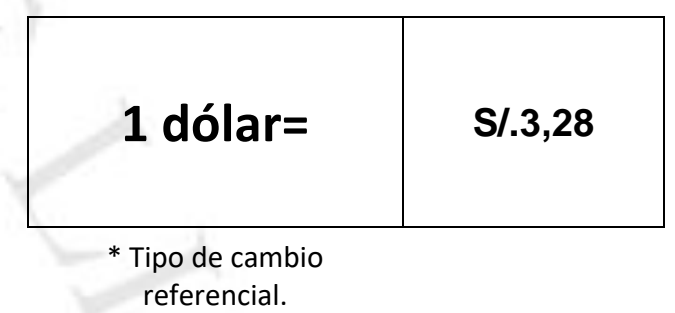

\begin{tabular}{|c|c|c|c|c|c|c|c|c|}
\hline COD. & Ítem & Unidad & Cantidad. & $\begin{array}{c}\text { Costo } \\
\text { Unitario }\end{array}$ & $\begin{array}{l}\text { Costo } \\
\text { Total en } \\
\text { Soles }\end{array}$ & $\begin{array}{l}\text { Total ítem } \\
\text { en Soles }\end{array}$ & Subtotales en Soles & $\begin{array}{l}\text { Totales en } \\
\text { dólares }\end{array}$ \\
\hline 1 & $\begin{array}{l}\text { GASTOS GENERALES } \\
\text { (todas las etapas) }\end{array}$ & & & & & & 78.200 & 23.841 \\
\hline 1.1 & \multicolumn{5}{|c|}{ ASPECTOS JURÍDICOS Y FINANCIEROS } & 2.000 & \multirow{7}{*}{8} & 610 \\
\hline 1.1.1 & $\begin{array}{l}\text { Asesoría legal y gastos } \\
\text { legales }\end{array}$ & Paquete & 1 & 1.000 & 1.000 & & & 305 \\
\hline 1.1 .2 & Gastos de timbre y notaría & Paquete & 1 & 500 & 500 & & & 152 \\
\hline 1.1.3 & $\begin{array}{l}\text { Gastos de transacciones, } \\
\text { transferencias bancarias y } \\
\text { otras }\end{array}$ & Paquete & 1 & 500 & 500 & & & 152 \\
\hline 1.1.4 & & Seleccionar & 0 & - & - & & & 0 \\
\hline 1.1 .5 & te & Seleccionar & 0 & - & - & & & 0 \\
\hline 1.1 .6 & & Seleccionar & 0 & - & - & & & 0 \\
\hline 1.2 & GASTOS ADMINISTRATIVOS & DE OFICINA & & & & 40.200 & & 12.256 \\
\hline
\end{tabular}




\begin{tabular}{|c|c|c|c|c|c|c|c|}
\hline 1.2.1 & Alquiler oficina & Meses & 12 & 1.500 & 18.000 & & 5.488 \\
\hline 1.2 .2 & $\begin{array}{l}\text { Servicios públicos (luz, agua, } \\
\text { gas) }\end{array}$ & Meses & 12 & 200 & 2.400 & & 732 \\
\hline 1.2 .2003 & Telefonía móvil & Meses & 12 & 600 & 7.200 & & 2.195 \\
\hline 1.2 .5 & $\begin{array}{l}\text { Gastos de conexión a } \\
\text { internet }\end{array}$ & Meses & 12 & 100 & 1.200 & & 366 \\
\hline 1.2 .6 & Insumos de oficina & Meses & 12 & 200 & 2.400 & & 732 \\
\hline 1.2 .7 & Alquiler equipos de oficina & Meses & 12 & 750 & 9.000 & & 2.744 \\
\hline 1.3 & PERSONAL ADMINISTRATIVC & Y SERVICIOS & & & & 36.000 & 10.976 \\
\hline 1.3.1 & Secretaria(s) & Semanas & 12 & 1.500 & 18.000 & & 5.488 \\
\hline 1.3 .3 & $\begin{array}{l}\text { Contador(es) y asistente } \\
\text { contable }\end{array}$ & Paquete & 12 & 1.500 & 18.000 & & 5.488 \\
\hline 2 & $\begin{array}{l}\text { PRE PRODUCCIÓN (12 } \\
\text { semanas) }\end{array}$ & & & & & & 36.247 \\
\hline 2,1 & PRODUCCIÓN & 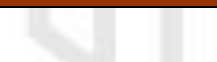 & 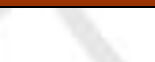 & & 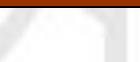 & 43.890 & 13.381 \\
\hline 2.1 .1 & Productor general & Meses & 3 & 6.500 & 19.500 & & 5.945 \\
\hline 2.1 .2 & Productor ejecutivo & Meses & 3 & 4.500 & 13.500 & & 4.116 \\
\hline 2.1 .3 & Coordinador de producción & Meses & 3 & 2.230 & 6.690 & & 2.040 \\
\hline 2.1 .4 & Asistente & Meses & 3 & 1.400 & 4.200 & & 1.280 \\
\hline 2,2 & $\begin{array}{l}\text { GUIÓN, DIRECCIÓN Y JEFES } \\
\text { DE ÁREA }\end{array}$ & & & & & 46.000 & 14.024 \\
\hline
\end{tabular}




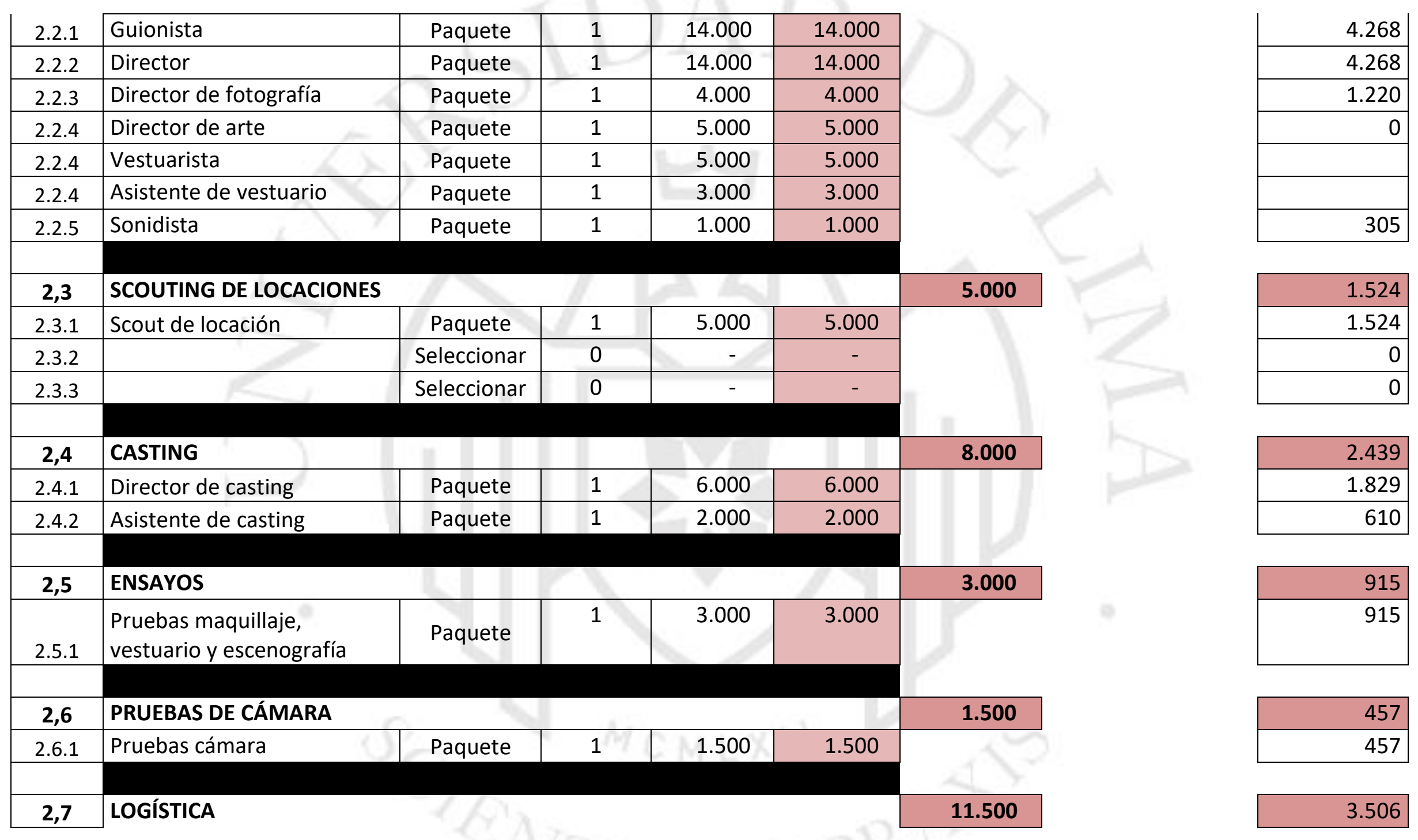




\begin{tabular}{|c|l|l|c|c|c|}
\cline { 2 - 5 } 2.7 .1 & $\begin{array}{l}\text { Transporte personas y carga } \\
\text { terrestre }\end{array}$ & Paquete & 1 & 10.000 & 10.000 \\
\hline 2.7 .5 & Peajes & Paquete & 1 & 1.500 & 1.500 \\
\hline & & &
\end{tabular}

\begin{tabular}{|c|c|c|c|c|c|c|c|c|}
\hline 3 & \multicolumn{6}{|l|}{ PRODUCCIÓN } & 751.000 & 228.963 \\
\hline 3,1 & \multicolumn{5}{|l|}{ PERSONAL DIRECCIÓN } & \multirow[t]{2}{*}{47.500} & & \multirow{2}{*}{$\begin{array}{r}14.482 \\
6.860 \\
\end{array}$} \\
\hline 3.1 .1 & Director(es) & Semanas & 5 & 4.500 & 22.500 & & & \\
\hline 3.1 .2 & Asistente de dirección & Semanas & 5 & 1.800 & 9.000 & & & 2.744 \\
\hline 3.1.4 & Continuista (Script) & Semanas & 5 & 1.400 & 7.000 & & & 2.134 \\
\hline 3.1 .5 & Foto fija & Semanas & 5 & 1.000 & 5.000 & & & 1.524 \\
\hline 3.1 .6 & Detrás de cámaras & Semanas & 5 & 800 & 4.000 & & & 1.220 \\
\hline 3,2 & PERSONAL PRODUCCIÓN & 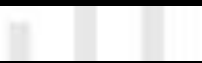 & & $y$ & & 52.500 & & 16.006 \\
\hline 3.2 .1 & Productor general & Semanas & 5 & 4.500 & 22.500 & & & 6.860 \\
\hline 3.2 .2 & Productor ejecutivo & Semanas & 5 & 2.500 & 12.500 & & & 3.811 \\
\hline 3.2 .3 & Coordinador de producción & Semanas & 5 & 1.000 & 5.000 & & & 1.524 \\
\hline 3.2 .4 & Asistente $\times 3$ & Semanas & 5 & 2.500 & 12.500 & & & 3.811 \\
\hline & & & & & & & & \\
\hline 3,3 & ELENCO & 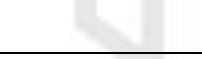 & & 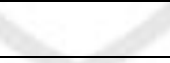 & & 110.000 & & 33.537 \\
\hline 3.3 .1 & Protagónicos x 3 & Paquete & 1 & 55.000 & 55.000 & & & 16.768 \\
\hline 3.3 .2 & Secundarios & Paquete & 1 & 35.000 & 35.000 & & & 10.671 \\
\hline 3.3 .3 & Figurantes & Paquete & 1 & 6.000 & 6.000 & & & 1.829 \\
\hline 3.3 .4 & Extras & Paquete & 1 & 4.000 & 4.000 & & & 1.220 \\
\hline 3.3 .5 & Dobles & Paquete & 1 & 10.000 & 10.000 & & & 3.049 \\
\hline
\end{tabular}




\begin{tabular}{|c|c|c|c|c|c|c|c|}
\hline 3,4 & \multicolumn{5}{|l|}{$\begin{array}{l}\text { PERSONAL DEPARTAMENTO } \\
\text { DE FOTOGRAFÍA }\end{array}$} & 81.000 & 24.695 \\
\hline 3.4 .1 & Director de fotografía & Semanas & 5 & 4.000 & 20.000 & & 6.098 \\
\hline 3.4 .2 & Operador de cámara & Semanas & 5 & 2.000 & 10.000 & & 3.049 \\
\hline 3.4 .3 & $\begin{array}{l}\text { Asistente de cámara I } \\
\text { (foquista) }\end{array}$ & Semanas & 5 & 1.500 & 7.500 & & 2.287 \\
\hline 3.4 .4 & Asistente de cámara II & Semanas & 5 & 1.000 & 5.000 & & 1.524 \\
\hline 3.4 .5 & $\begin{array}{l}\text { Técnico de imagen digital } \\
\text { (DIT) }\end{array}$ & Semanas & 5 & 1.000 & 5.000 & & 1.524 \\
\hline 3.4 .6 & Luminotécnico (Gaffer) & Semanas & 5 & 1.700 & 8.500 & & 2.591 \\
\hline 3.4 .7 & Asistente de luces I & Semanas & 5 & 1.000 & 5.000 & & 1.524 \\
\hline 3.4 .8 & Asistente de luces II & Semanas & 5 & 1.000 & 5.000 & & 1.524 \\
\hline 3.4 .9 & Otros asistentes de luces & Semanas & 5 & 900 & 4.500 & & 1.372 \\
\hline 3.4 .10 & Maquinista & Días & 10 & 700 & 7.000 & & 2.134 \\
\hline 3.4 .11 & Electricista & Semanas & 5 & 700 & 3.500 & & 1.067 \\
\hline 3,5 & $\begin{array}{l}\text { PERSONAL DEPARTAMENTO } \\
\text { DE ARTE }\end{array}$ & & & & & 87.000 & 26.524 \\
\hline 3.5 .1 & Director de arte & Semanas & 5 & 3.000 & 15.000 & & 4.573 \\
\hline 3.5 .2 & Asistente de arte I & Semanas & 5 & 1.500 & 7.500 & & 2.287 \\
\hline 3.5 .3 & Otros asistentes de arte & Semanas & 5 & 800 & 4.000 & & 1.220 \\
\hline 3.5 .4 & Productor de arte & Semanas & 5 & 1.600 & 8.000 & & 2.439 \\
\hline 3.5 .5 & $\begin{array}{l}\text { Coordinador de efectos } \\
\text { especiales }\end{array}$ & Semanas & 1 & 5.000 & 5.000 & & 1.524 \\
\hline 3.5 .7 & Montajista & Semanas & 5 & 1.000 & 5.000 & & 1.524 \\
\hline
\end{tabular}




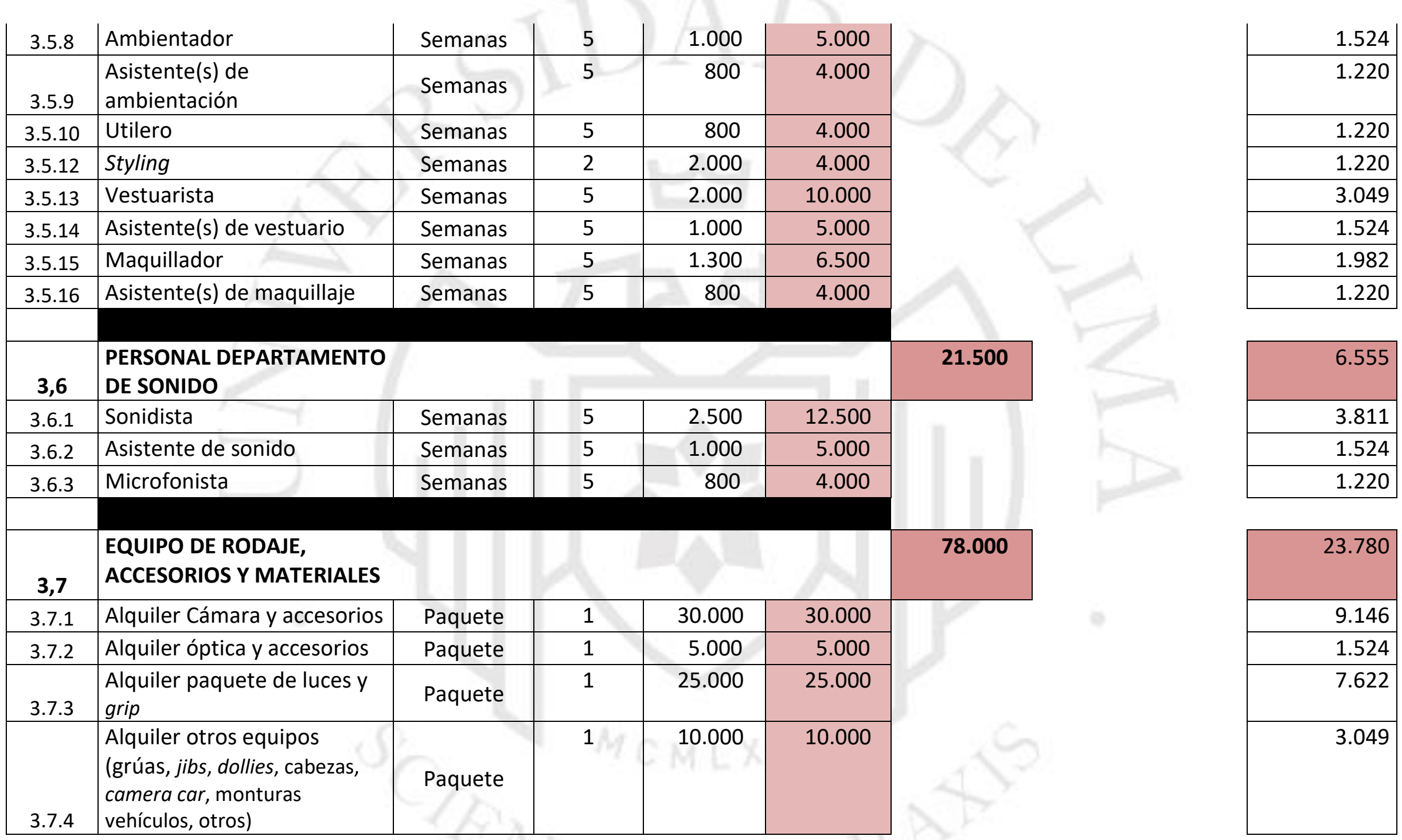




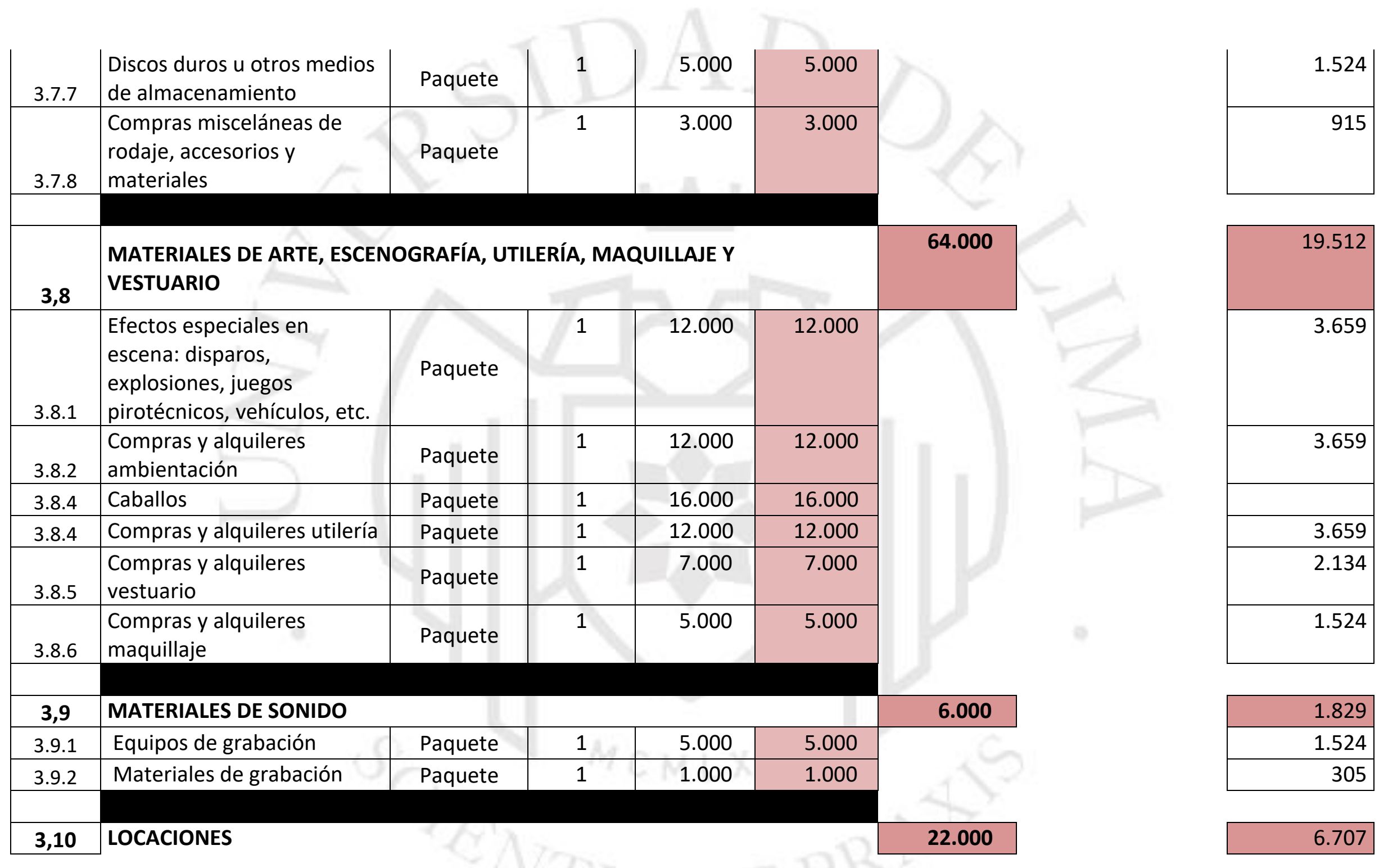




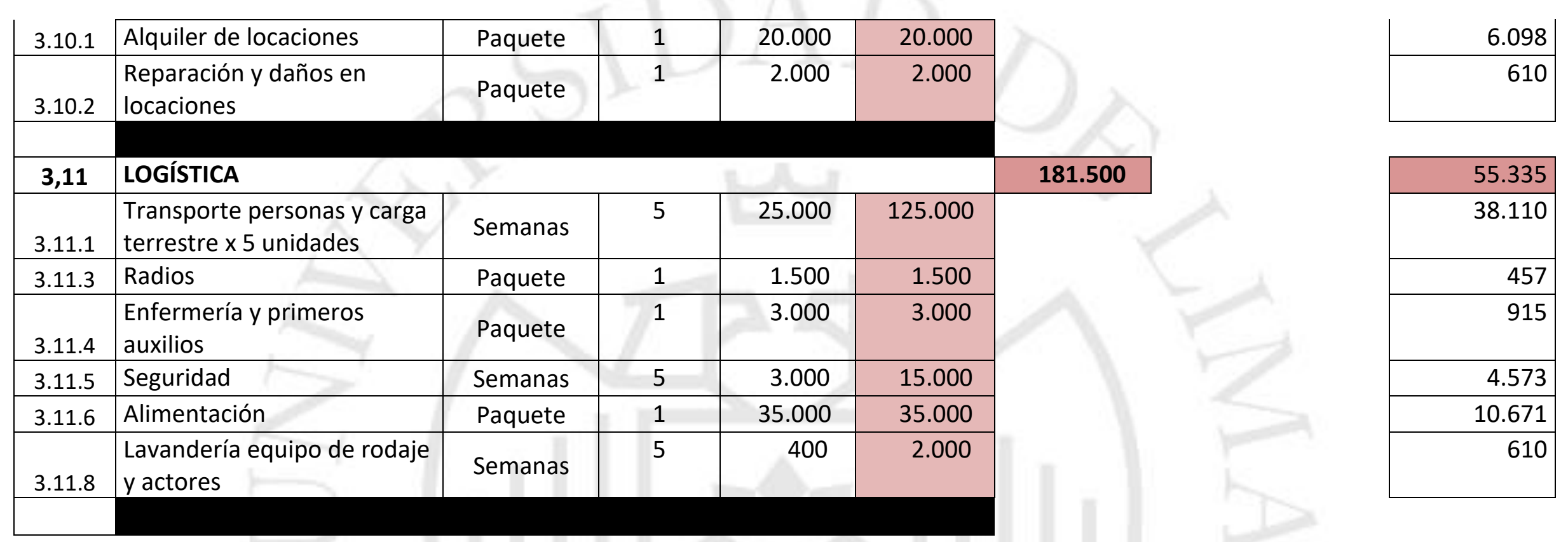

\begin{tabular}{|c|c|c|c|c|c|c|c|c|}
\hline 4 & POST PRODUCCIÓN & & & & & & 158.500 & 48.323 \\
\hline 4,1 & EDICIÓN & & & 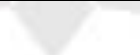 & the & 31.000 & \multirow{5}{*}{$\theta$} & 9.451 \\
\hline 4.1 .1 & Montaje & Paquete & 1 & 15.000 & 15.000 & \multirow[t]{4}{*}{ 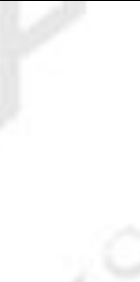 } & & 4.573 \\
\hline 4.1 .2 & Asistente de edición I & Paquete & 1 & 5.000 & 5.000 & & & 1.524 \\
\hline 4.1 .3 & Otros asistentes de edición & Paquete & 1 & 3.000 & 3.000 & & & 915 \\
\hline 4.1.4 & $\begin{array}{l}\text { Alquiler de equipos de } \\
\text { edición }\end{array}$ & Paquete & 1 & 8.000 & 8.000 & & & 2.439 \\
\hline 4,2 & LABORATORIO & & & & & 6.000 & & 1.829 \\
\hline
\end{tabular}




\begin{tabular}{|c|c|c|c|c|c|c|c|}
\hline 4.2 .1 & $\begin{array}{l}\text { Coordinador de } \\
\text { postproducción }\end{array}$ & Paquete & 1 & 6.000 & 6.000 & & 1.829 \\
\hline 4.2 .2 & Revelado negativo & Paquete & 0 & - & - & & 0 \\
\hline 4.2 .3 & Telecine o transfer & Paquete & 0 & - & - & & 0 \\
\hline 4.2 .4 & $\begin{array}{l}\text { Digitalización o escáner en } \\
\text { alta resolución }\end{array}$ & Paquete & 0 & - & - & & 0 \\
\hline 4.2 .5 & Restauración y limpieza & Paquete & 0 & - & - & & 0 \\
\hline 4,3 & FINALIZACIÓN & 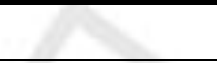 & 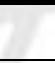 & 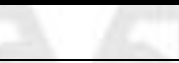 & 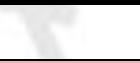 & 48.300 & 14.726 \\
\hline 4.3 .1 & Conformación & Paquete & 1 & 13.500 & 13.500 & & 4.116 \\
\hline 4.3 .2 & Corte de negativo & Seleccionar & 1 & - & - & & 0 \\
\hline 4.3 .3 & Etalonaje o dosificado & Seleccionar & 1 & - & - & & 0 \\
\hline 4.3.4 & Interpositivo, Internegativo & Seleccionar & 1 & - & - & & 0 \\
\hline 4.3 .5 & Colorización & Paquete & 1 & 13.000 & 13.000 & & 3.963 \\
\hline 4.3 .6 & Estereoscopía & Seleccionar & 1 & 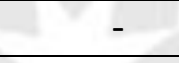 & - & & 0 \\
\hline 4.3.7 & $\begin{array}{l}\text { Subtitulación (subtitulación, } \\
\text { subtitulación DCP, spotting } \\
\text { list, traducciones) }\end{array}$ & Paquete & 1 & 3.300 & 3.300 & & 1.006 \\
\hline 4.3.8 & $\begin{array}{l}\text { Composición (diseño de } \\
\text { títulos y créditos) }\end{array}$ & Paquete & 1 & 3.500 & 3.500 & & 1.067 \\
\hline 4.3 .9 & Efectos visuales & Paquete & 1 & 15.000 & 15.000 & & 4.573 \\
\hline 4,4 & ENTREGA (incluye película y & ráiler) & & & & 14.500 & 4.421 \\
\hline 4.4 .1 & Data to film & Seleccionar & 0 & - & - & & 0 \\
\hline 4.4 .2 & Copia 0 y posteriores & Paquete & 1 & 5.000 & 5.000 & & 1.524 \\
\hline 4.4 .3 & Codificación DCP - DCl & Paquete & 1 & 3.000 & 3.000 & & 915 \\
\hline
\end{tabular}




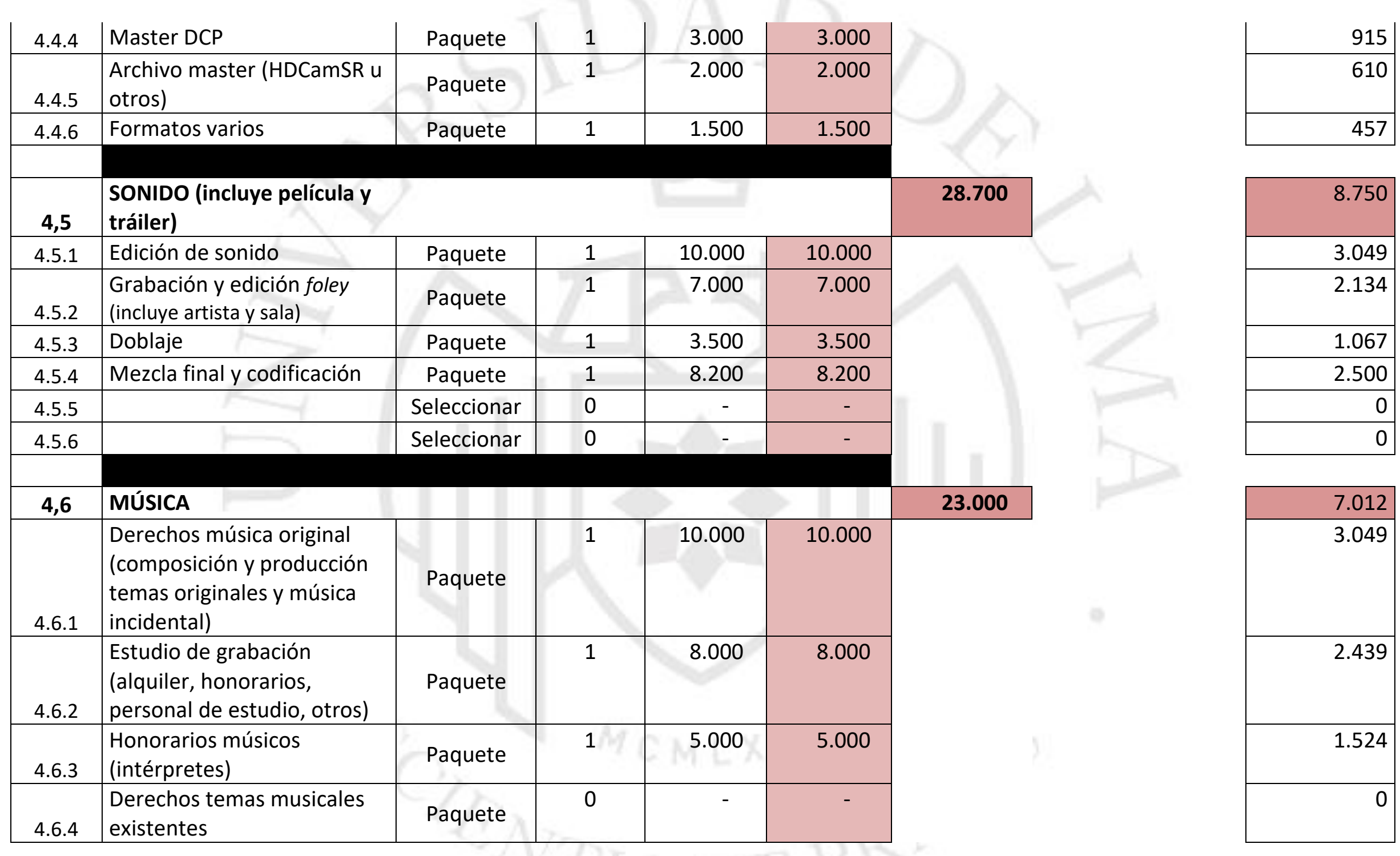




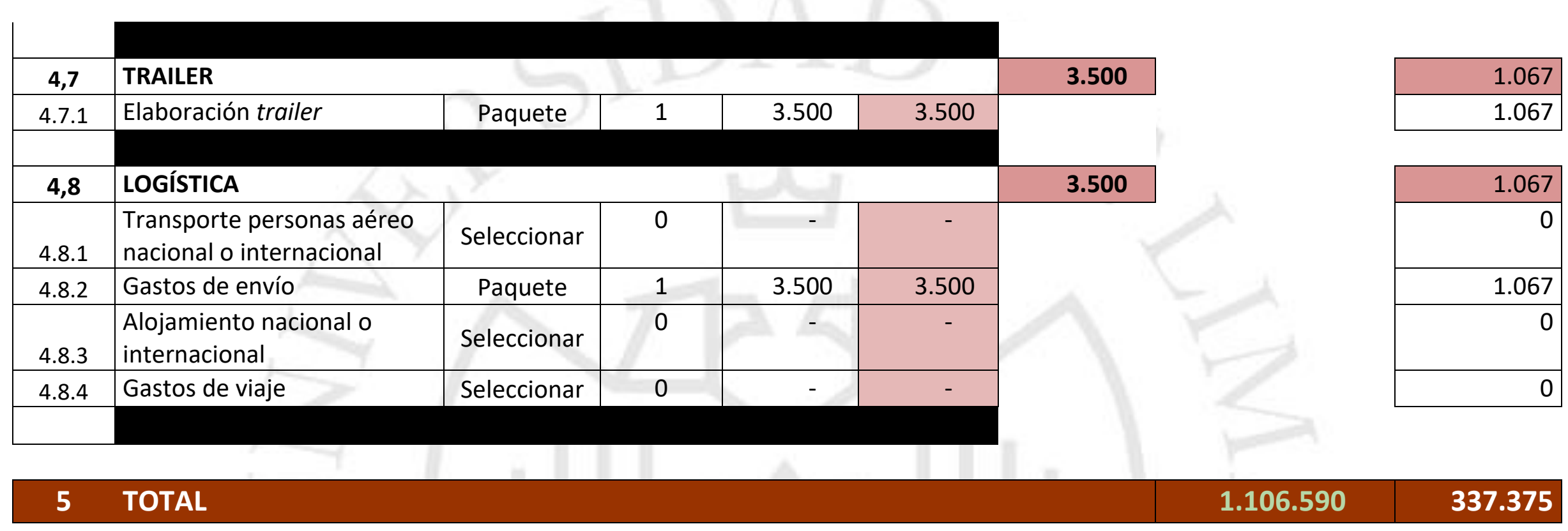

Nota: La tabla es un presupuesto de la película El Chalán tomando el modelo DAFO como referencia. Esta tabla se puede encontrar en un documento drive en el siguiente link:

https://docs.google.com/spreadsheets/d/1wXgCWTcs5tPwgkQvUWq0aO9tNwemgYOJKWR9TY1ZbAM/edit\#gid=979371632

Fuente: Propia. 


\subsection{Fuentes de financiamiento}

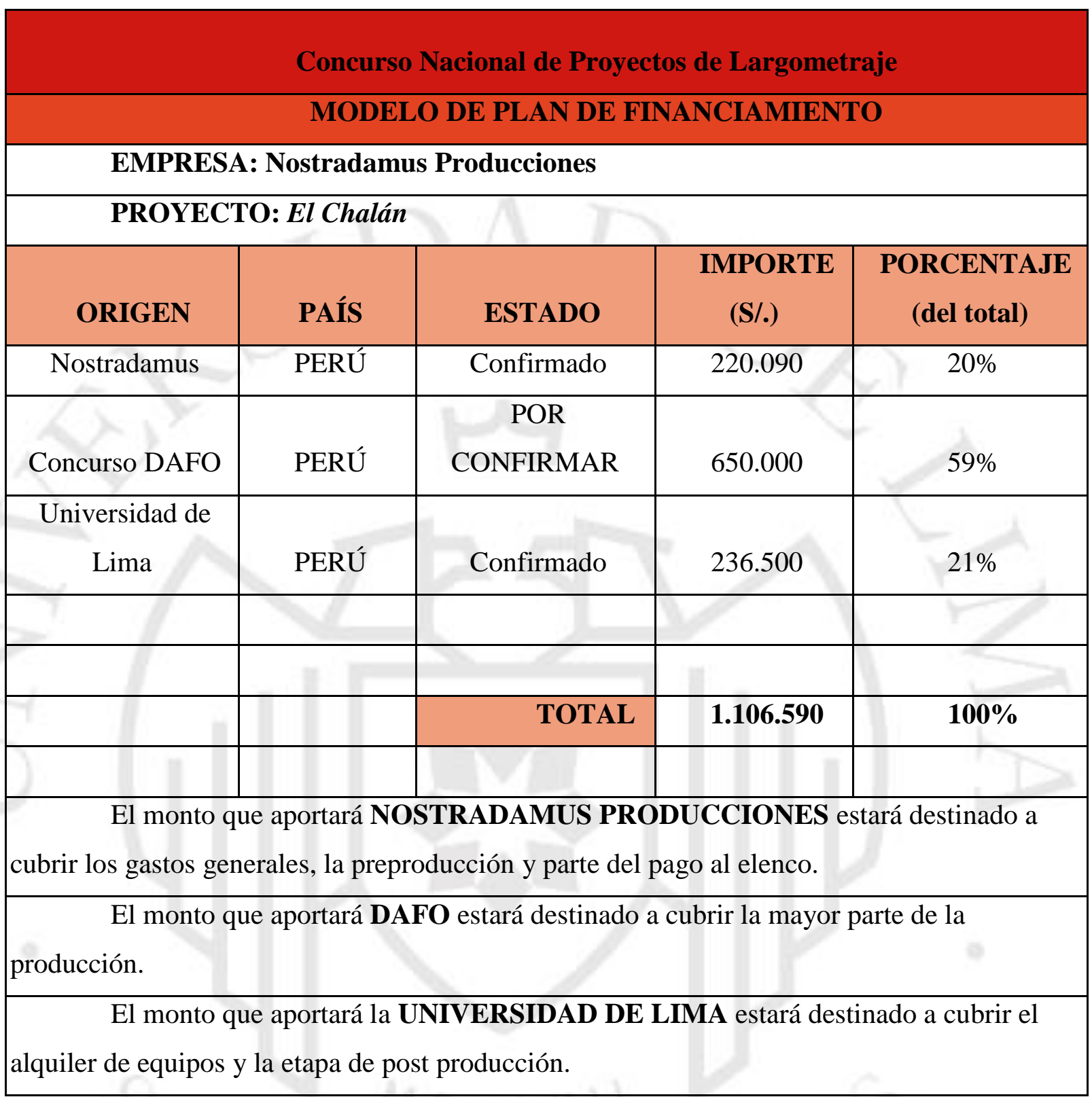

\subsection{Fuentes de financiamiento alterno}

Tenemos la posibilidad de proponer un plan de financiamiento alternativo que permita la viabilidad del proyecto en caso no se llegara a contar con los fondos provenientes del Concurso Dafo.

Este plan alternativo será contemplado tomando en cuenta las siguientes opciones de financiamiento: 
INVERSIÓN DE EMPRESAS PRIVADAS. La nueva ley de cine es una oportunidad de invitar a participar del proyecto a diversas empresas del sector privado bajo la modalidad de donaciones y que estas sean beneficiadas con la deducción fiscal respectiva. Consideramos que un proyecto como El Chalán puede resultar bastante atractivo para empresas privadas vinculadas a los siguientes sectores:

- Productores de pisco

- Asociación de criadores de caballos de paso

- Empresas vinculadas al sector turístico

Empresas vinculadas al sector gastronómico

En la entrevista a Beyker Bances nos sugiere acudir a las cámaras de comercio ya que podrían funcionar como puentes para acceder a las empresas.

FONDO INTERNACIONAL. Proponemos postular El Chalán al Fondo Ibermedia, si bien no se trata de una fuente de financiamiento directa, ya que parte del monto obtenido, debe ser reembolsado al fondo. Se trata de una opción que en primera instancia puede hacer viable el inicio del proyecto.

MODALIDAD DE COPRODUCCIÓN. Proponemos visitar, como parte de esta estrategia de financiamiento alterno, algunos de los eventos y mercados de industrias creativas más representativos de la región que nos den la posibilidad de establecer alianzas previas a la realización del proyecto como, por ejemplo: Bolivia Lab, Bogotá audiovisual market, Ventana Sur en Argentina o Morelia Lab en México. 
CAPÍTULO VIII: CRONOGRAMA 
Tabla 8.1

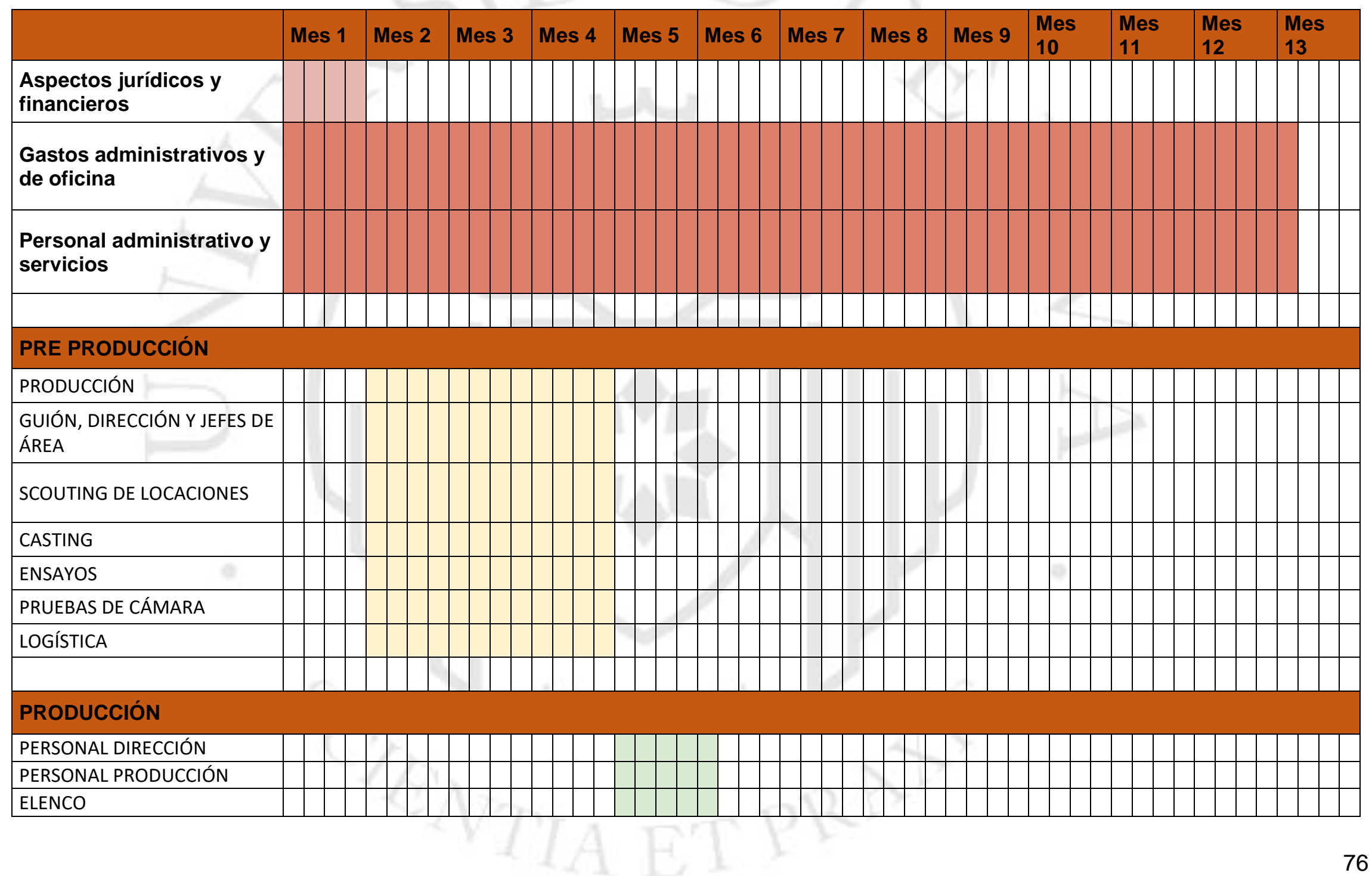


PERSONAL DEPARTAMENTO

DE FOTOGRAFÍA

PERSONAL DEPARTAMENTO

DE ARTE

PERSONAL DEPARTAMENTO

DE SONIDO

EQUIPO DE RODAJE,

ACCESORIOS Y MATERIALES

MATERIALES DE ARTE,

ESCENOGRAFÍA, UTILERÍA,

MAQUILLAJE Y VESTUARIO

MATERIALES DE SONIDO

LOCACIONES

LOGÍSTICA

\section{POST PRODUCCIÓN}

EDICIÓN

LABORATORIO

FINALIZACIÓN

ENTREGA (incluye película y

tráiler)

SONIDO (incluye película y

tráiler)

MÚSICA

TRAILER

LOGÍSTICA

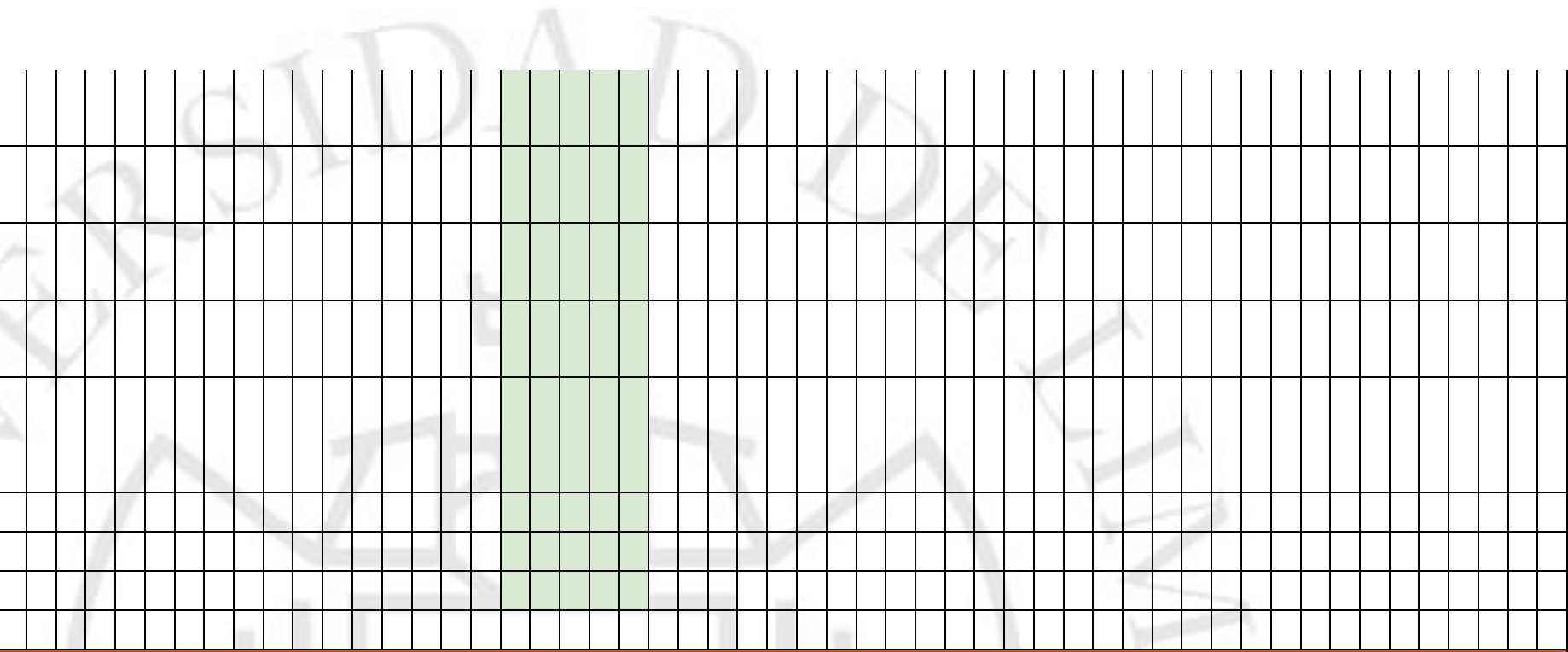

DISTRIBUCIÓN Y

PROMOCIÓN 


\section{ANEXOS}

\section{PERFIL DE PERSONAJES}

\section{El Chalán (José Luis Ruiz)}

Es un hombre misterioso de pocas palabras, caballero y justiciero. Tiene alrededor de 45 a 50 años. Monta a caballo con soltura y garbo, ya que es un experto domador. Se define como un nómade, no tiene un lugar fijo dónde vivir si no que va de pueblo en pueblo transportando pisco y ayudando a la gente. Usa un sombrero de ala ancha y poncho para evitar los rayos solares en el día y dormir abrigado de noche. Es también un experto en el uso de armas ya que sirvió como soldado en la Guerra con Chile. En esa época estuvo en el regimiento 77 al mando del comandante Cahua más conocido como Cuto. En esta etapa de su vida vio todos los abusos que cometió su comandante, por lo que lo denunció y fue expulsado del ejército.

\section{El Cuto (Reynaldo Arenas)}

Es un hombre de presencia fuerte, mirada penetrante, ambicioso y corrupto. Es manco y tiene alrededor de 70 a los 75 años. Es un líder nato, siempre tiene a 2 o 3 subordinados que cumplen sus órdenes sin miramientos. Usa un sombrero de ala corta y un uniforme militar desgastado, ya que participó en la guerra con Chile, tenía el cargo de comandante del regimiento 77. Aprovechando su posición de poder abusaba de los pobladores del lugar donde era asignado su regimiento. Al ver estos abusos El Chalán lo denunció frente a sus superiores, pero el Cuto se las arregló para que no fuera tomada en 
cuenta su denuncia. Esto motivó a una pelea entre los dos, en la que el Cuto pierde un brazo y fueron expulsados de la milicia. El Cuto se convirtió en el líder de una banda de delincuentes que cobran cupos a los pobladores.

\section{Claudia (María Angélica Vega)}

Claudia es una mujer de una belleza exótica. Tiene alrededor de 45 a 50 años. Es una experta bailando la marinera. No sabe montar a caballo. Es dueña del fundo Los Tilos donde produce pisco y trabaja para que se convierta en uno de los fundos más importantes de la zona. Viste de forma sencilla y cómoda para poder trabajar en el campo, una falda larga y una blusa. Tiene una personalidad fuerte, pero a la vez soñadora y romántica. Le encanta que un hombre sea galante con ella.

\section{La peque (Mayra Goñi)}

La peque es hija de Claudia, de quien heredó su belleza. Tiene alrededor de 20 a 25 años. Es muy aguerrida e impetuosa. Peca muchas veces de soberbia porque trata de demostrar que ya no es una pequeña chica inmadura. Se termina enamorando de Puñal.

\section{Puñal (Gustavo Borjas)}

Puñal es parte de la banda del Cuto. Tiene alrededor de 20 a 25 años. Es un experto en el uso de armas blancas (de allí su apodo). Es un mercenario ambicioso y fanfarrón. Está enamorado de La peque. 


\section{CONTEXTO}

EL CHALÁN es una producción ambientada en el norte del Perú a finales del siglo XIX, postguerra con Chile. No debe juzgarse como una película histórica sino más bien como un cuento o una leyenda, de allí que la película comience con el crédito: "Hace mucho tiempo, en algún lugar del Perú..."

\section{TRATAMIENTO}

Hace mucho tiempo,

en algún lugar del Perú..

En el desierto del norte peruano. El viento azota el desolado lugar. A lo lejos se ve lo que parece ser una persona con su caballo atravesando el territorio a suave trote.

Vemos ahora de cerca al personaje, EL CHALÁN. El caballo no es un caballo cualquiera. Es un caballo blanco de paso. EL CHALÁN lo maneja con elegancia, vistiendo un atuendo también blanco y un sombrero costeño de ala ancha.

Crédito de la Película: EL CHALÁN

En el fundo los Tilos unos tres malhechores le piden un cupo a CLAUDIA, la dueña del lugar, quien se niega a darles algo. Los malhechores empiezan a saquear la casa. Sale entonces LA PEQUE, hija de CLAUDIA, una joven impetuosa y rebelde que trata de enfrentarse a los malhechores. CLAUDIA aprovecha la distracción y coge el rifle, pero uno de los malhechores se da cuenta y se realiza un disparo al aire.

EL CHALÁN escucha el disparo y saca de su morral un revolver y se dirige hacia el fundo con su caballo. 
Dos de los malhechores han reducido a CLAUDIA y a su hija ven como llega $E L$ CHALÁN y tranquilamente deja a su caballo amarrado. Los ladrones extrañados le preguntan qué quiere. Habla en voz alta mencionando que el destino lo ha llevado por allí. Le pregunta si se encuentra bien a CLAUDIA y ella trata de responder, pero el malhechor le da una cachetada. EL CHALÁN se bate en duelo con los ladrones y los vence debido a la rapidez con que maneja su arma, pero no sabía que uno de los malhechores todavía seguía dentro de la casa. Este silenciosamente le apunta al CHALAN con su escopeta preparado para asesinarlo. CLAUDIA se da cuenta de la trampa en que va a caer EL CHALÁN y rápidamente encuentra una piedra y logra desviar el disparo. El malhechor huye, EL CHALÁN se desmaya con una herida en el brazo.

El malhechor que escapó llega hasta una especie de casa abandonada en las afueras. Entra y un grupo de tres hombres están en un festín. Se presenta ante EL CUTO, el jefe de esta banda de malhechores, le comunica que no pudieron recolectar el cupo por la llegada del visitante. EL CUTO se sonríe. Hace referencia a que lo conoce. Nos quedamos con la imagen del malhechor más joven llamado PUÑAL.

Vemos imágenes propias de una pesadilla: El chalán se encuentra en medio de una batalla bastante confusa aparecen imágenes del Cuto y de un personaje masculino que termina muriendo a "manos del Chalán" antes de morir el misterioso hombre le orgina un corte en el brazo izquierdo. EL CHALÁN despierta agitado y nervioso en una cama dentro de una habitación del fundo los Tilos. Se queda viendo la cicatriz como recordando el momento de la pesadilla. Se levanta, coloca el brazo en su camisa a modo de cabestrillo, recoge su poncho y sale de la casa.

EL CHALÁN se para en la puerta. No ve a nadie, suena de pronto el relincho de su caballo. EL CHALÁN camina hacia el lugar de donde sonó.

EL CHALÁN ve a lo lejos a CLAUDIA acariciando a su caballo.

CLAUDIA mira fijamente al caballo y lo trata de acariciar, pero el caballo se aleja.

EL CHALÁN le dice que tiene que hacerlo lentamente y sin miedo, ella se sonríe y le agradece por ayudarla con los malhechores. Ella se presenta y le advierte que esos 
malhechores eran parte de la banda de... y antes que pudiera terminar EL CHALÁN completa la frase, la banda del CUTO. Lo conoce y le cuenta que viene por él que tienen cuentas pendientes que saldar. Ella le cuenta que anteriormente en su fundo producían Pisco pero que ahora los terrenos eran regentados por el CUTO y su banda cobrando cupos abusivos. Cuando ella trata de averiguar más sobre él, EL CHALÁN desvía la conversación hacia su caballo y le muestra como montarlo. EL CHALÁN sobre el caballo da vueltas alrededor de CLAUDIA (tipo marinera). Ella queda encantada y hay cierto coqueteo entre ellos. Cuando EL CHALÁN se detiene, sus miradas se cruzan. En ese momento llega LA PEQUE a interrumpir el momento, recelosa por su madre y EL CHALÁN. CLAUDIA trata de presentar a su hija, pero ella toma la iniciativa. EL CHALÁN sonríe. al momento de darle su mano LA PEQUE nota que EL CHALÁN tenía una pulsera particular. Ella le menciona que su Padre también tuvo una, le cuenta que él murió combatiendo en la guerra con Chile. EL CHALÁN le cuenta que él también luchó en esa guerra y que a los soldados les entregaban esa pulsera. Le pregunta por el nombre de su padre y ella le dice que se llamaba OCTAVIO RAMIREZ. Ante esta respuesta EL CHALÁN apresura su salida.

Le indica a CLAUDIA que tiene que partir en búsqueda del CUTO. Ella menciona que está herido, la bala todavía sigue en su brazo y que al menos le deje llevarlo al "doctor" del pueblo. EL CHALÁN acepta pero se le percibe algo nervioso.

PUÑAL, el malhechor más joven, observa escondido cómo CLAUDIA, LA PEQUE y EL CHALÁN salen del fundo hacia el pueblo.

Al llegar al pueblo CLAUDIA señala una casa. Dentro de la casa, un hombre gordo algo entrado en años se encuentra sentado frente a una mesa con una botella de Pisco, tiene signos de estar dormido. Suena la puerta varias veces, pero el hombre no reacciona. Cansado del ruido, el hombre grita que se vayan. CLAUDIA contesta los gritos y el hombre reconoce la voz. Antes de abrir la puerta el hombre guarda el Pisco. Al ver a CLAUDIA se alegra y hace pasar al Chalán. CLAUDIA presenta al hombre como MENDOZITA, el doctor del pueblo, pero EL CHALÁN solo ve a un borracho.

LA PEQUE, quien se quedó afuera del lugar cuidando los caballos es sorprendida por PUÑAL quien le tapa la boca y la lleva a un callejón. 
MENDOZITA prepara sus instrumentos para sacarle la bala al CHALAN, sus manos están temblando. Agarra la botella de pisco y toma un sorbo. La tembladera cesa y coge sus instrumentos para sacar la bala.

En el callejón, PUÑAL al parecer le va a hacer algo a LA PEQUE, pero ella se abalanza sobre él y le da un gran beso. Ella inicialmente le dice que lo extraña pero luego le increpa del por qué fueron esos malhechores a su casa. PUÑAL le dice a LA PEQUE que no podía hacer nada, que él se encontraba en otra misión encomendada por el CUTO. PUÑAL le advierte a LA PEQUE que se alejen de EL CHALÁN, que el CUTO lo está buscando. Ella le dice que no confía en EL CHALÁN, siente que esconde algo. Luego escucha que su madre y EL CHALÁN salen del doctor. Se despiden con otro beso.

LA PEQUE se une a su madre y al Chalán para regresar a asa, mientras están saliendo del pueblo, PUÑAL está observando cómo se retiran. De pronto de un momento a otro PUÑAL pierde de vista al Chalán, solo ve a su caballo. En ese momento EL CHALÁN se encuentra detrás de PUÑAL, este se levanta rápidamente y saca unos Puñales con los que va a combatir. EL CHALÁN al ver que es un muchacho deja el arma y se propone enfrentarlo a puño limpio, aunque tenga un brazo inhabilitado en el cabestrillo. Empiezan a luchar y EL CHALÁN logra esquivar un par de estocadas, le empieza a dar algunos golpes y termina reduciendo a PUÑAL. Cuando está a punto de noquearlo llega LA PEQUE a defenderlo. Confiesa que está enamorada de él. Su madre se sorprende y trata de alejarlo de él. Ella se resiste.

EL CHALÁN amarra a PUÑAL y lo lleva a la comisaría del pueblo para que lo encierren. El comisario en vez de arrestar a PUÑAL tratan de arrestar al chalán. Vemos que el sistema de justicia está controlado por el CUTO. EL CHALÁN enfrenta al comisario en un duelo y lo vence.

Antes de salir de la comisaría EL CHALÁN se da cuenta que no hay ningún ruido en la calle, mira por la ventana y no ve a nadie... ni CLAUDIA, ni LA PEQUE. Observa bien y ve que a lo lejos se encuentra el CUTO y que tiene a CLAUDIA y a LA PEQUE. El CUTO le dice que salga que se encuentra rodeado. EL CHALÁN le dice que tiene a 
su secuaz PUÑAL. CUTO le dice que no le importa y que él tiene de rehén a CLAUDIA y a LA PEQUE. PUÑAL se sorprende con la respuesta del CUTO.

EL CUTO se queda esperando. Ve a lo lejos salir de la comisaría a la figura del Chalán con su sombrero, su poncho y sus brazos levantados. Le pide que se acerque. Lentamente se acerca. Cuando lo tiene a una distancia cercana el CUTO le apunta directamente con la pistola. Le dice que ha esperado este momento por mucho tiempo. EL CHALÁN levanta el sombrero y se da cuenta que es PUÑAL que se había disfrazado del Chalán. Ve a su alrededor y todos los malhechores han sido reducidos por EL CHALÁN. Este se encuentra en la parte de arriba de una de las casas apuntando al CUTO. Al verse en esta situación el CUTO toma de rehén a CLAUDIA, agarrándola del cuello. El Cuto les cuenta a todos que el Chalán no es tan buena persona como todos creen, que también fue un delincuente, que él fue parte de su banda durante la guerra. Y que él también saqueó y asesinó a inocentes.

FASHBACK: Escena de la guerra, hace referencia a las imágenes de la "Pesadilla". El Chalán se encuentra como parte del escuadrón del Cuto, que entran a saquear las casas de los inocentes.

Le dice que tú no eres mejor que yo, ya no te acuerdas cuando ¿asesinaste a Ramirez?

FLASHBACK: RAMIREZ es parte del regimiento del CHALÁN. El era el segundo al mando y quería asesinar a los pobladores. EL CHALÁN no podía permitirlo y por eso terminó por dispararle a RAMIREZ.

LA PEQUE queda conmocionada al descubrir que el CHALÁN es el "responsable" de la muerte de Ramirez.

El CUTO reta al CHALÁN a un duelo en el valle de la Chaira como en los viejos tiempos para acabar con esto de una vez por todas. El CUTO se va con CLAUDIA como rehén. 
Al día siguiente en el valle de la Chaira CUTO, está sentado esperando al Chalán. CLAUDIA está amarrada y amordazada. Hay una larga espera hasta que aparece $E L$ CHALÁN caminando.

EL CHALÁN camina hasta el centro del valle. El CUTO va a su encuentro. CLAUDIA ve llegar al Chalán y observa que hay un MALHECHOR escondido.

Tienen una conversación, EL CHALÁN le advierte que se retire y el CUTO se niega. Los dos se preparan para el duelo, la tensión crece entre EL CHALÁN y el CUTO, CLAUDIA desesperada trata de avisarle al Chalán que el MALHECHOR está escondido, pero no puede. Hay un paralelo entre los 4 personajes. Finalmente se escuchan dos disparos. Por un momento todos se quedan quietos. Cae de pronto el MALHECHOR y luego el CUTO, en el piso está moribundo y no termina de comprender qué pasó. EL CHALÁN mantiene su pistola con el brazo derecho (con el que disparó al CUTO). Pero saca de su camisa su brazo herido mostrando otra pistola más pequeña (con la que disparó al MALHECHOR). El CUTO cae sin más en el piso. EL CHALÁN guarda sus pistolas y va donde CLAUDIA, a desamarrarla. CLAUDIA le dice al CHALÁN que entiende lo que hizo, que ella sabía que su ex esposo era un militar corrupto, su relación estaba distanciada pero nunca se atrevió a contarle la verdad a su hija quien lo tenía en un altar, ella no sabía de todo lo que era capaz de hacer su padre.

EL CHALÁN llega con CLAUDIA al fundo, LA PEQUE y PUÑAL han escapado. EL CHALÁN decide ir en búsqueda de LA PEQUE, aclarar la situación, traerla junto a su madre. Desaparece galopando con su caballo por el horizonte.

FIN 


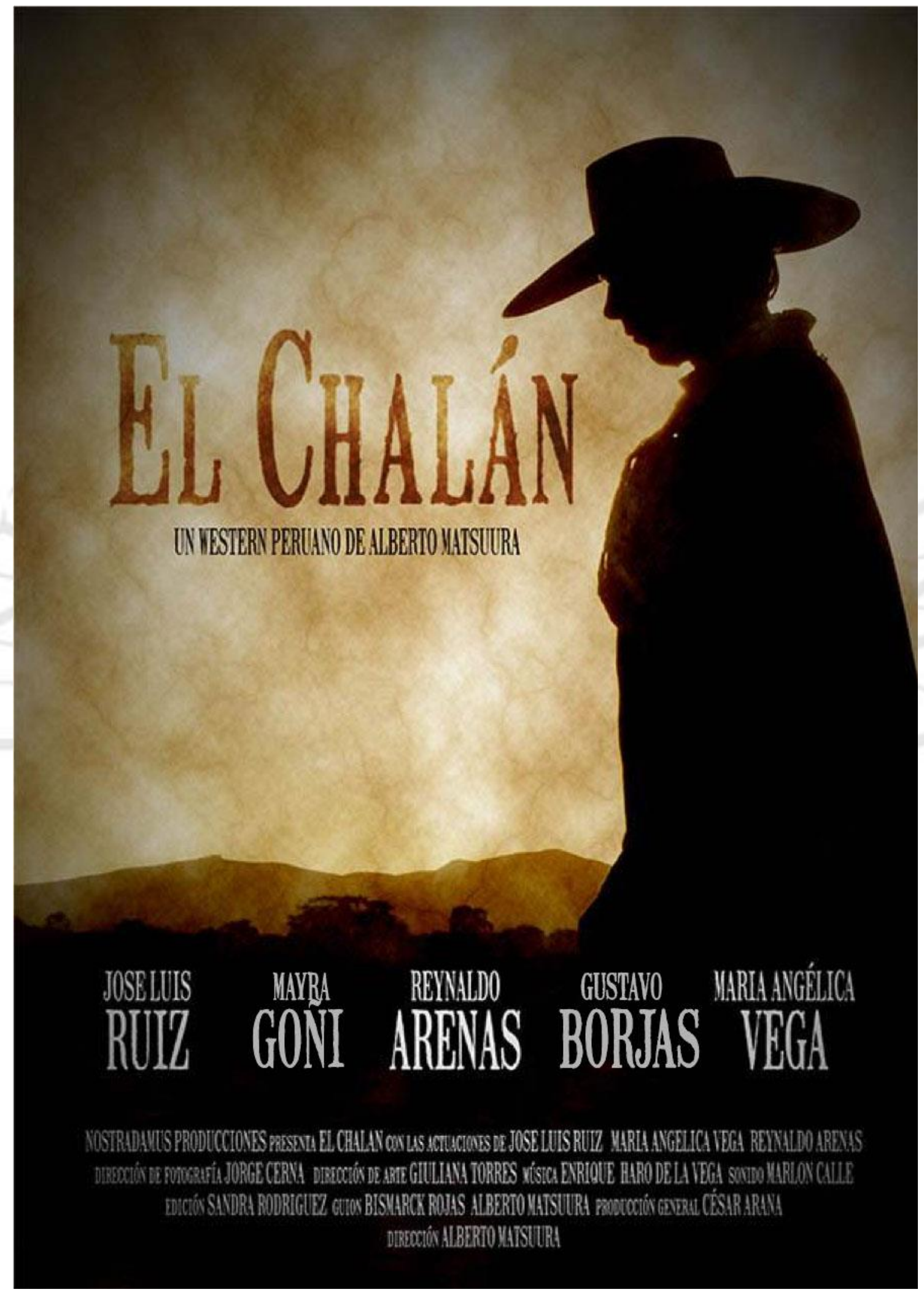




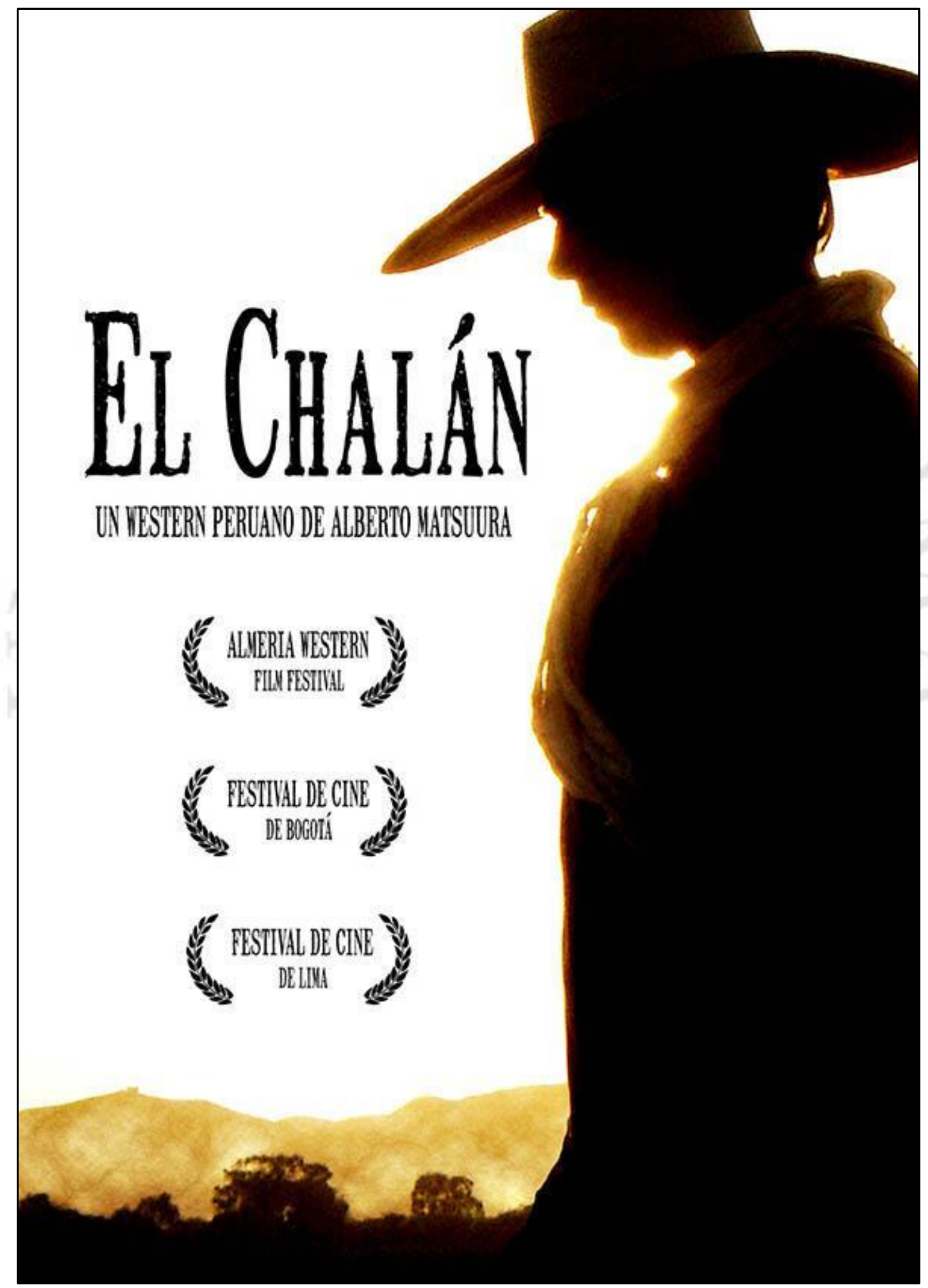




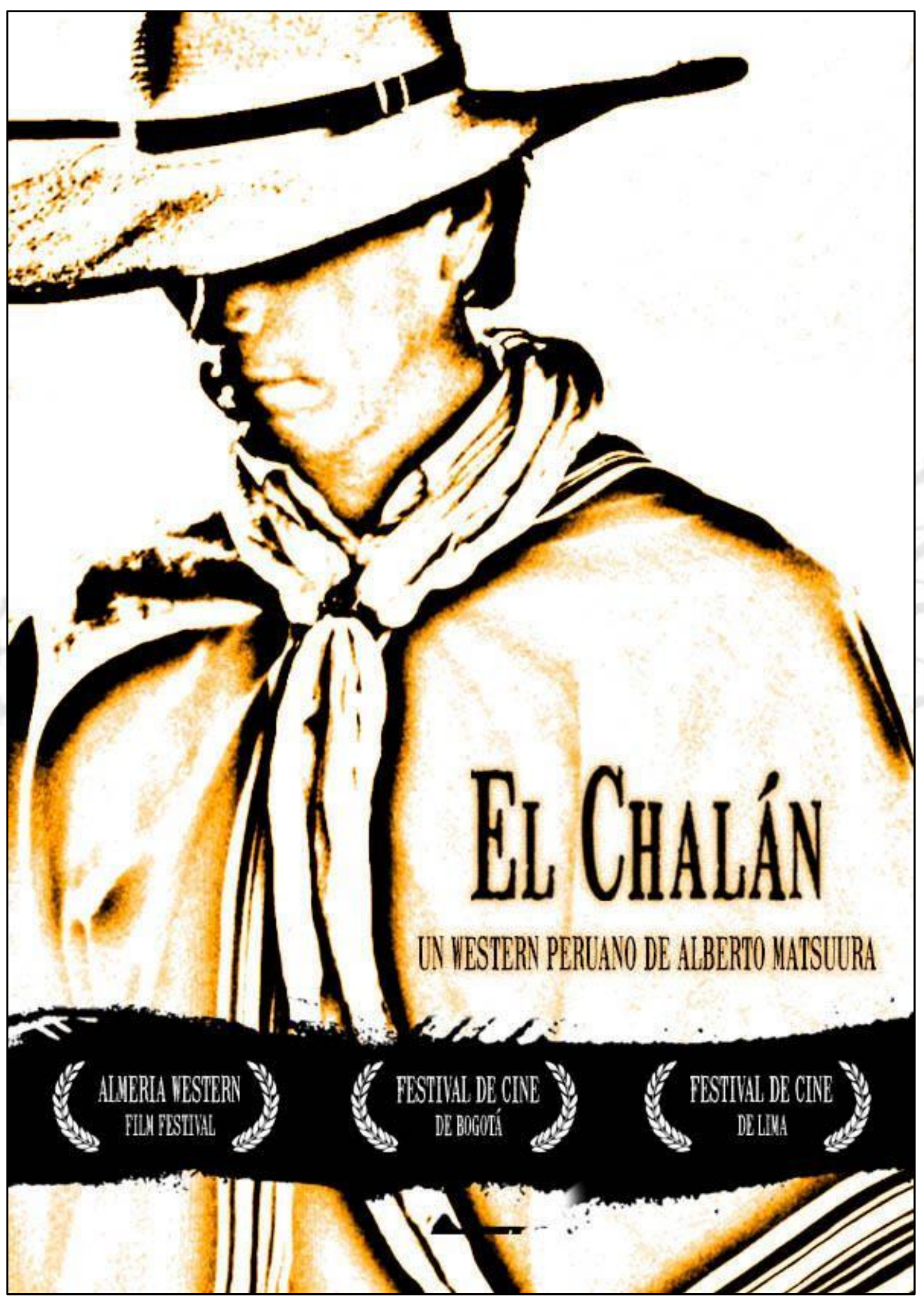




\section{ENTREVISTA A BEYKER BANCES}

El 25 de octubre del 2019, se realizó una entrevista a Beyker Bances, productor de la película Pueblo Viejo, la cual se puede oír completa a través del siguiente link:

https://drive.google.com/drive/folders/14ORmG817Z27VSGvOE61ce2VKIVt

$\underline{\mathrm{MnMtg}}$ 


\section{BIBLIOGRAFÍA}

Akamine, J. (2017, abril 10). El Comercio. From El Comercio: https://elcomercio.pe/eldominical/actualidad/mueve-industria-cinematograficaperu-413161-noticia/

Blum, J. (2016, agosto 03). Jonathan Blum. From Jonathan Blum: https://www.jonathanblum.tv/es/cine-america-latina/

Blum, J. (2016, Agosto 03). Jonathan Blum. From Jonathan Blum: https://www.jonathanblum.tv/cine-america-latina/

Casas, Q. (1994). El western - El género americano. Barcelona: Ediciones Paidos.

Chávez , R. (2019, marzo 10). Cinencuentro. From Cinencuentro: https://www.cinencuentro.com/2019/03/10/analisis-taquilla-cine-peruano-2018parte-2/

Chávez, R. (2019, febrero 07). Cineencuentro. From Cineencuentro: https://www.cinencuentro.com/2019/02/07/analisis-taquilla-cine-peruano-2018/

Dafo. (2016). Infoartes. From Infoartes: http://dafo.cultura.pe/wpcontent/uploads/2017/03/Bolet\%C3\%ADn-Infoartes-Sector-audiovisual.pdf

Ganamás. (2019, Junio 13). Ganamás. From Ganamás: https://revistaganamas.com.pe/laindustria-de-cine-facturo-s-428-4-millones-en-peru-el-2018/

Gestión Empresas. (2019, noviembre 01). Gestión Empresas. From Gestión Empresas: https://gestion.pe/economia/empresas/pwc-industria-cinematografica-perucrecera-32-6-2022-245548-noticia/

Instituto de Investigación Científica de la Universidad de Lima. (2013, Mayo 13). Universidad de Lima. From Universidad de Lima: http://www.ulima.edu.pe/pregrado/comunicacion/noticias/las-razones-del-exitode-asu-mare 
Matsuura, A. (2014, Mayo 19). Youtube. From Youtube: https://www.youtube.com/watch?v=ss1W8vIKH9w\&feature=youtu.be \&t=5

Perú 21. (2019, Septiembre 09). Perú 21. From Perú 21: https://peru21.pe/economia/abriran-128-nuevas-salas-cine-peru-proximos-cincoanos-proyecta-pwc-500592-noticia/

Tamayo, A., \& Hendrickx, N. (2018). Financiamiento, distribución y marketing del cine peruano. Lima: Universidad de Lima.

Valladares Vives, M. (2018, septiembre 03). Cinencuentro. From Cinencuentro: https://www.cinencuentro.com/2018/09/03/entrevista-miguel-valladarestondero-peliculas-peruanas/

Velásquez, S. (n.d.). Somos Periodismo. From Somos Periodismo: http://somosperiodismo.com/netflix-las-plataformas-streaming-la-revoluciondel-consumo-series-peliculas/

Zegarra, J. (2019, agosto 03). ItUsers. From ItUsers: https://itusers.today/habitoscinematograficos-de-los-peruanos/ 